\title{
Modelo Comportamental Baseado em CrenÇAS E TEORIA BAYESIANA PARA SIMUlaÇÕES DE VIDA ARTIFICIAL COM HuMANOS VIRTUAIS
}

Dissertação apresentada à Escola Politécnica da Universidade de São Paulo para obtenção do Título de Mestre em Engenharia Elétrica.

SÃO PAULO 2006 
Este exemplar foi revisado e alterado em relação à versão original, sob responsabilidade única do autor e com a anuência de seu orientador.

São Paulo, 10 de Maio de 2006.

Assinatura do autor

Assinatura do orientador

FICHA CATALOGRÁFICA

Cavalhieri, Marcos Antonio

Modelo comportamental baseado em crenças e teoria bayesiana para simulações de vida artificial com humanos virtuais / M.A. Cavalhieri. -- São Paulo, 2006.

$95 \mathrm{p}$.

Dissertação (Mestrado) - Escola Politécnica da Universidade de São Paulo. Departamento de Engenharia de Sistemas Eletrônicos.

1.Inteligência artificial 2.Representação do conhecimento 3.Aprendizado computacional 4.Realidade Virtual I.Universidade de São Paulo. Escola Politécnica. Departamento de Engenharia de Sistemas Eletrônicos II.t. 


\section{Modelo Comportamental Baseado em CrenÇAS E TEORIA BAYESIANA PARA SIMUlaÇÕES DE VIDA ARTIFICIAL COM HuMANOS VIRTUAIS}

Dissertação apresentada à Escola Politécnica da Universidade de São Paulo para obtenção do Título de Mestre em Engenharia Elétrica.

Área de Concentração:

Engenharia de Sistemas Eletrônicos

Orientador:

Prof. Dr. Marcio Lobo Netto

SÃO PAULO

2006 


\begin{abstract}
"É melhor tentar e falhar, que se preocupar e ver a vida passar; é melhor tentar, ainda que em vão, que se sentar fazendo nada até o final. Eu prefiro na chuva caminhar, que em dias tristes em casa me esconder. Prefiro ser feliz, embora louco, que em conformidade viver..."
\end{abstract}

[Martin Luther King]. 


\section{AgradeCimentos}

Aos meus pais e familiares pelo apoio e carinho incondicional que em inúmeros momentos serviram de alento e amparo para superar mais este obstáculo da ciência e da vida.

Ao meu orientador por ter se empenhado tão incisivamente como provocador do conhecimento, pelas discussões que só vieram a enriquecer ainda mais este trabalho de coalizão de idéias, por ter me motivado e acreditado no meu potencial, quando eu próprio já o questionava. Enfim, agradeço por sua disponibilidade e paciência que culminaram na transformação de um sonho em contribuição científica.

A professora $\operatorname{Dr}^{\mathrm{a}}$ Maria das Graças Bruno Marietto que contribuiu significativamente desde as discussões preliminares dessa pesquisa. A ela que sempre se mostrou tão prestativa e ávida a me ajudar com o seu conhecimento e experiência, além da sincera amizade que emergiu desse processo de pesquisas e discussões.

Ao Laboratório de Sistemas Integráveis (LSI) por ter me acolhido e servido de incubador ao oferecer as condições e recursos necessários ao desenvolvimento dessa pesquisa.

Aos meus amigos, sinceros, leais, perseverantes e tão obstinados que sempre estiveram ao meu lado com uma palavra de apoio ou com momentos de descontração. 


\section{RESUMO}

O trabalho reúne características relacionadas aos escopos de pesquisa de Vida e Inteligência Artificial, Ciência Cognitiva, e Realidade Virtual. O objetivo primordial é a concepção de um modelo de comportamento autônomo e adaptativo que permita a interação do personagem virtual num ambiente, mesmo dispondo de informações incertas e vagas. Sob esse intuito o projeto desenvolve a conciliação de recursos para tratarem a idéia de racionalizar sobre tais incertezas, promovendo assim, a capacidade de agir assumindo-se alguns riscos decorrentes desse caráter inexato. Por conseqüência, os humanos virtuais são capazes de observarem o ambiente no qual se situam, apresentarem representações internas e racionalizadas dessas informações incertas, que no trabalho são levantadas como crenças, e ainda tomarem decisões baseadas nessas informações. Através do processo de decisão o personagem é capaz de reavaliar as suas crenças; implicando em um comportamento maduro em decorrência dos procedimentos usados para deliberar e realizar ações em um ambiente virtual. 


\section{AbStract}

This work puts together features related to the research areas of Artificial Life, Artificial Intelligence, Cognitive Science and Virtual Reality. The main goal of this work is the conception of an adaptive and autonomous behavior model which alows the interaction, even with uncertain information, between a virtual character and an environment. Therefore, resources are organized to be handled rationally with uncertainties, thus, the ability to act assuming some risks of this inexact aspect are granted. The results enable the virtual humans to observe their environment, to present internal and rationalized representations of this uncertain information, represented in this work as beliefs, and taking decisions based on this information. Through the decision process, the character can re-evaluate its beliefs; which imply in a mature behavior, as a consequence of how procedures are used to deliberate and to perform actions in a virtual environment. 


\section{SUMÁRIO}

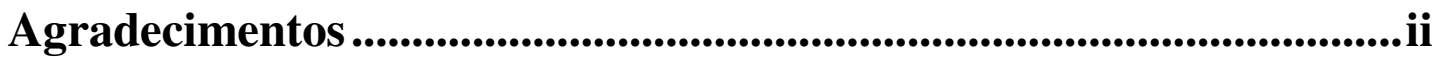

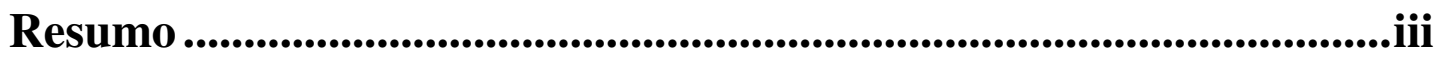

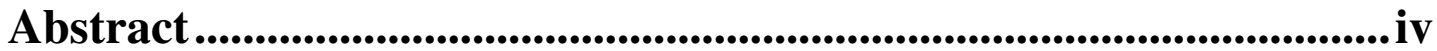

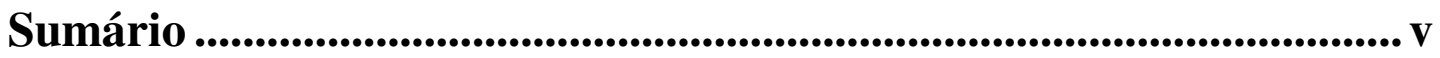

Lista de Tabelas............................................................................................viii

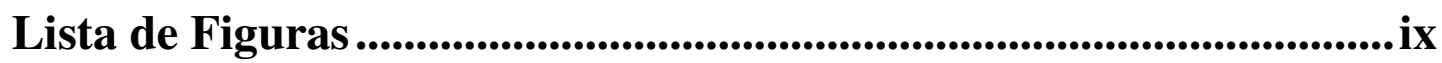

1 Introduçãa............................................................................................................. 1

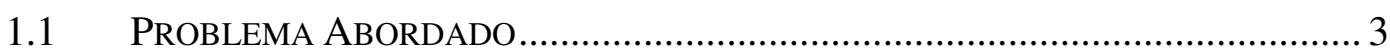

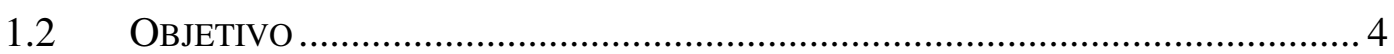

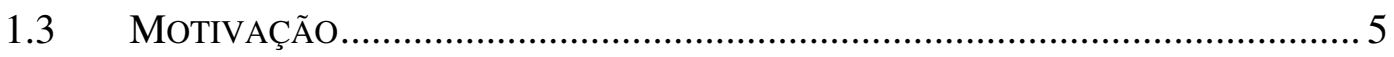

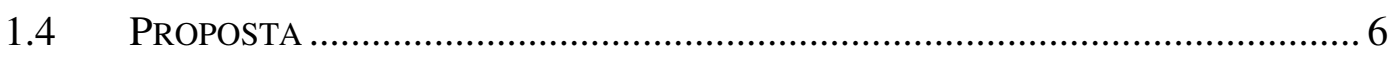

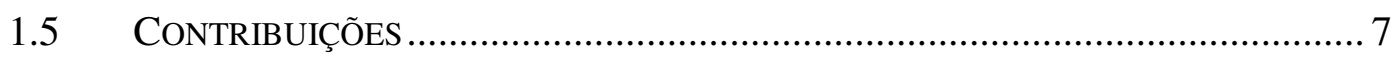

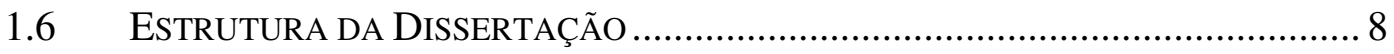

2 Vida e Inteligência Artificial ......................................................9

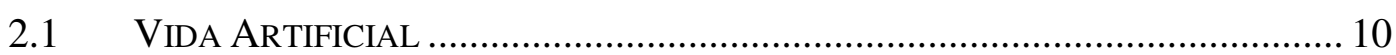

2.1.1 Fenômenos Observados em Vida ....................................................... 11

2.1.2 Classificação de Projetos em Vida Artificial...................................... 12

2.1.3 Principais Trabalhos e Simulações.................................................. 14

2.2 A INTELIGÊNCIA ARTIFICIAL COMO FERRAMENTA...................................... 17 


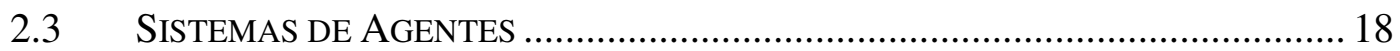

2.3.1 Framework do Comportamento de Agentes...................................... 18

2.3.2 Desempenho e Racionalidade de Agentes.......................................... 19

2.3.3 Tópicos de Racionalidade ................................................................... 21

2.3.4 Propriedades dos Ambientes em IAD ............................................. 23

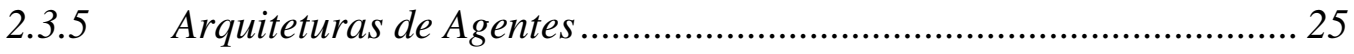

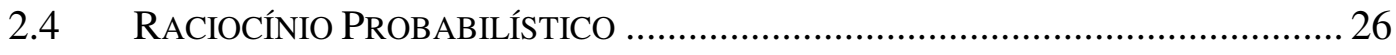

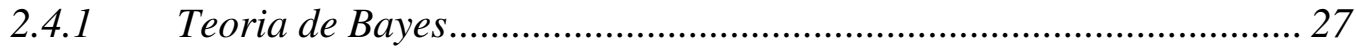

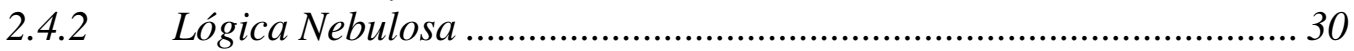

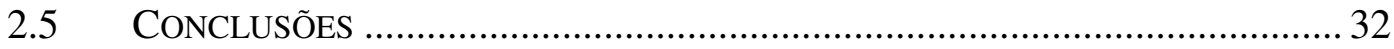

3 Visualização de Simulações ......................................................................33

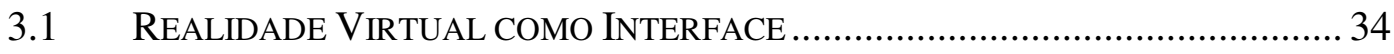

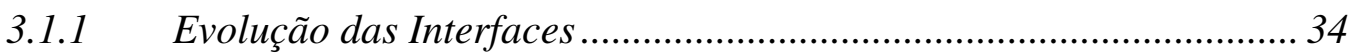

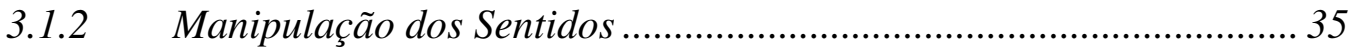

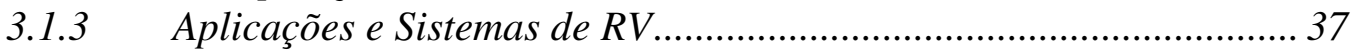

3.2 Humanos ViRTUAis AutônOMOS ........................................................... 38

3.2.1 Aplicações em Meios Digitais............................................................ 38

3.2.2 Aspectos Envolvidos na Representação e Controle ........................... 42

3.2.3 Humanos Virtuais como Avatares........................................................ 44

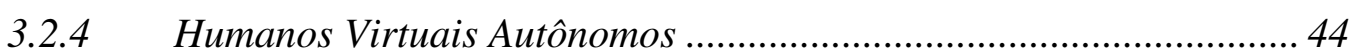

3.2.5 Humanos Virtuais com Comportamento Social ................................. 47

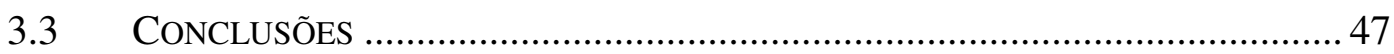

4 Modelagem do Comportamento Cognitivo .....................................49

4.1 ESPECIFICAÇÃO DO PROJETO............................................................. 50

4.1.1 Análise Através do Contexto de Vida Artificial ................................. 50

4.1.2 Modelo Fundamentado em Inteligência Artificial .............................. 51

4.1.3 Raciocínio Probabilístico como Processo Cognitivo ......................... 53

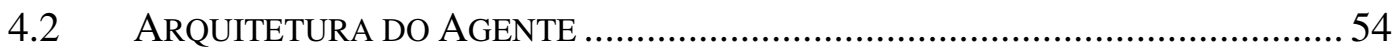

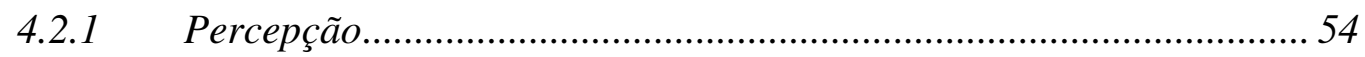

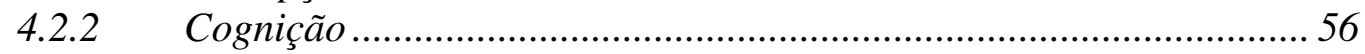

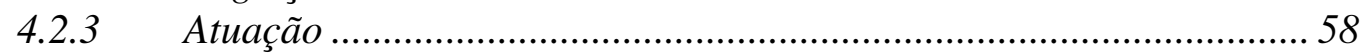

4.3 REPRESENTAÇÃO E MANIPULAÇÃO DA INCERTEZA..................................... 59

4.4 MOdELO DE FunCIONAMENTO DO AMBIENTE ….......................................... 64

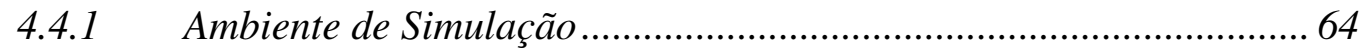

4.4.2 Conhecimento Relacional ..................................................................... 64

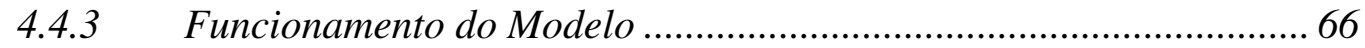


4.4.4 Relação entre Papel, Fato, Crença e Ação........................................ 69

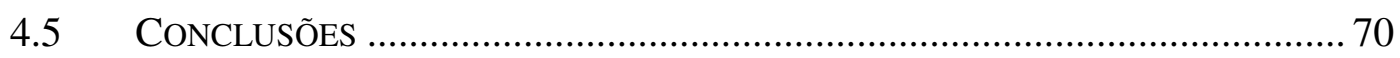

5 Análise dos Resultados da Simulação..........................................72

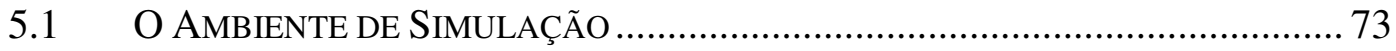

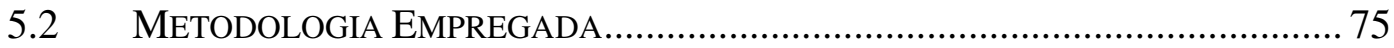

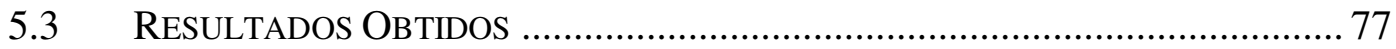

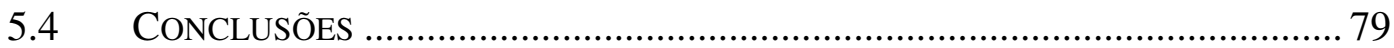

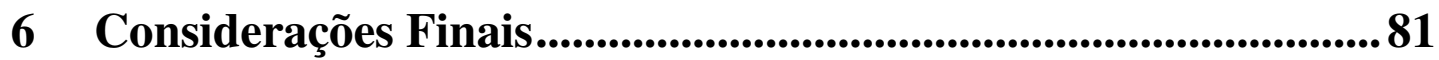

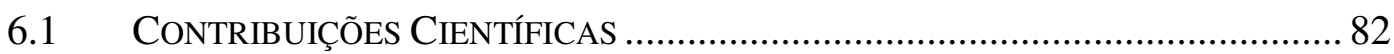

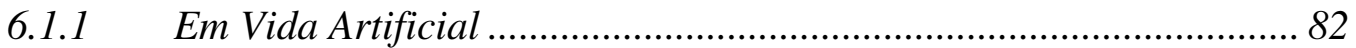

6.1.2 Em Inteligência Artificial............................................................ 83

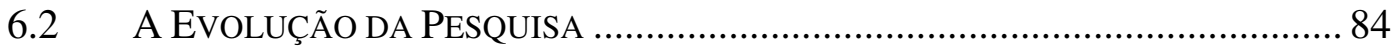

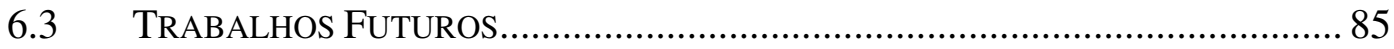

Levantamento Bibliográfico.........................................................................88

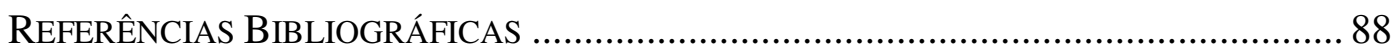

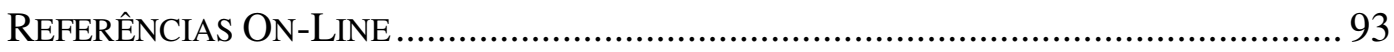




\section{LISTA DE TABELAS}

Tabela 1: Quadro de evidências conhecidas pelo agente.........................................2 29

Tabela 2: Quadro de hipóteses (crenças) conhecidas pelo agente. ............................ 29

Tabela 3: Quadro de probabilidades das evidências na certeza da hipótese $\mathrm{P}(\mathrm{e} / \mathrm{h}) \ldots 29$

Tabela 4: Quadro de regras que utiliza a sintaxe Modus Ponens para computar palavras. 30

Tabela 5: Descrição dos parâmetros que compõem um Fato. 55

Tabela 6: Relacionamento desejado entre os valores de fato e crença (Dominante). 65

Tabela 7: Relacionamento da Ação entre papel (objetivo pessoal) e a crença sobre o observado.

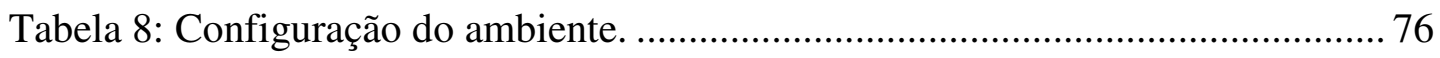

Tabela 9: Distribuição dos humanos entre os papéis. ............................................... 76

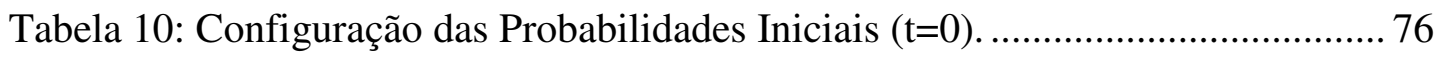

Tabela 11: Configuração das Probabilidades a priori (F e C)................................. 76

Tabela 12: Valores iniciais da tabela I(f/c) que serão corrigidos............................. 76

Tabela 13: Tabela de crenças NC(c/f) que serão calculados (a posteriori).................76 


\section{LISTA DE FIGURAS}

Figura 1: Espaço tridimensional de VA formado pela tríade: Filo, Onto e Episteme.

Figura 2: Evolução de seres compostos por estruturas primárias (Sims, 2005)......... 14

Figura 3: WOXBOT e o processo evolutivo ao longo das gerações (Miranda, 2001).

Figura 4: Simulações de Vida Artificial com peixes e dinâmica Presa-Predador...... 15

Figura 5: ALGA e a arquitetura que descreve o comportamento dos peixes (Netto, 2004). 16

Figura 6: Simulação de multidões integradas por Humanos Virtuais (Musse, 2006).

Figura 7: Esquematização dos módulos responsáveis pelo funcionamento de um agente.

Figura 8: Teorema de Bayes.

Figura 9: Gráfico dos níveis de pertinência dos conjuntos nebulosos (Kaehler, 2005).

Figura 10: Disposição da Caverna Digital da USP. 36

Figura 11: Eva Byte: Apresentadora Virtual (Amaral, 2004). 39

Figura 12: Personagem Kaya (Batistão, 2006). 40

Figura 13: Eureka: Comentarista Virtual de Esportes (Vilela, 2006). 41

Figura 14: Jogo de Simulação da Vida Social Humana (TheSims, 2006). 41

Figura 15: Tela Principal do Navegador do Active Worlds (Active, 2006). 42

Figura 16: Espaço tridimensional contextualizando o projeto V1V0 em Vida Artificial.

Figura 17: Framework utilizado como base para o desenvolvimento do modelo do projeto. 
Figura 18: Processo Cognitivo baseado em duas etapas.........................................54

Figura 19: Comunicação entre o humano e o oráculo. ...............................................55

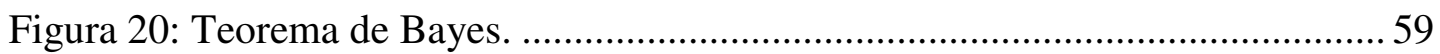

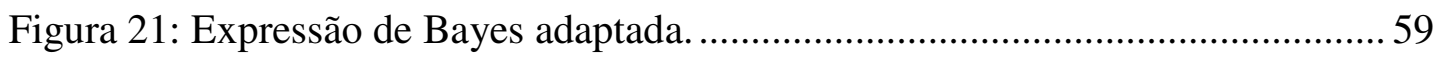

Figura 22: Expressão proposta para cálculo da certeza através da teoria de Bayes... 60

Figura 23: Expressão proposta para o cálculo do viés de crença.............................. 61

Figura 24: Parâmetros a priori do cálculo bayesiano, Fatos e Crenças

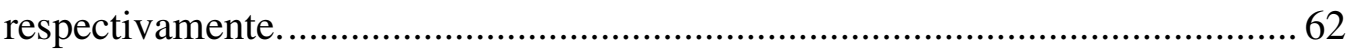

Figura 25: Expressão proposta para o cálculo do viés de fato. ..................................62

Figura 26: Evolução dos valores do Vf (t) para todos os fatos (cores)......................63

Figura 27: Relacionamento entre fato e crença para desenvolvimento de

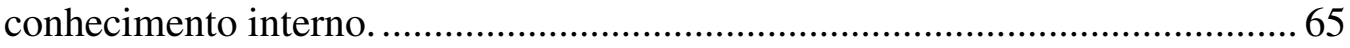

Figura 28: Algoritmo de funcionamento do modelo...............................................67

Figura 29: Modelo da Cognição e do funcionamento do Ambiente. .......................... 68

Figura 30: Modelo do relacionamento entre as informações fato, crença e ação. ..... 69

Figura 31: Ambiente de Simulação........................................................................... 73

Figura 32: Tópico de Simulação Gráfica da dinâmica de tráfico............................... 74

Figura 33: Tópico da arquitetura do agente contendo informações sobre o repertório de um determinado humano da sociedade. ..................................................... 75

Figura 34: Curvas de convergência dos níveis de certeza....................................... 77

Figura 35: Gráfico de ascendência da dispersão (desvio padrão) dos índices de

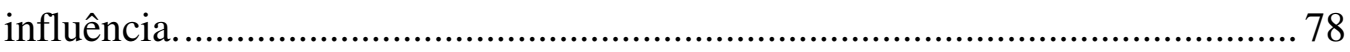

Figura 36: Curvas de experimentação da sociedade. 


\title{
1 INTRODUÇÃO
}

\author{
"A força de trabalho... é um produto \\ primário, nem mais nem menos \\ importante que o açúcar. o primeiro é \\ medido pelo relógio, e o segundo pela \\ balança"
}

[Karl Marx]. 
O homem sempre vislumbrou a possibilidade de utilizar as máquinas como mecanismos através dos quais pudesse modelar características humanas. Sobretudo, os aspectos relacionados à inteligência e à habilidade de adaptação; os quais acabaram contextualizando o profundo intento da Inteligência Artificial (IA).

A partir destes anseios, bem como os referentes ao poder da vida e o da criação, a ciência passou a questionar assuntos como: o paradoxo orgânico e o nãoorgânico (máquinas), a capacidade de sentimento, os conflitos entre homens e máquinas, dentre outros. Tais questionamentos acarretaram em uma reflexão ainda mais profunda sobre os benefícios (ou malefícios) da delegação de inteligência e autonomia as máquinas.

Filosofia e ciência à parte, a evolução tecnológica confirma algumas aspirações feitas pelos profissionais da área de IA, enquanto que outras mal chegaram a ser cogitadas como prováveis em um dado futuro, e ainda revolucionaram áreas tidas como de ordem primária à manutenção humana, como por exemplo: a medicina. Contudo, áreas tais como a indústria do entretenimento, também obtiveram contribuições substanciais.

Algumas das contribuições em aspectos gerais que podem ser observadas são: o comportamento de personagens melhor desenvolvidos e a qualidade gráfica para representações de pessoas ou objetos em ambientes virtuais. Estas contribuições permitem ao usuário um maior envolvimento com o sistema computacional. Assim, aplicativos que fazem uso de representações tridimensionais cuja geometria e movimentação sejam o mais próximo possível de um humano, bem como um comportamento desenvolvido por esta estrutura, ganharam uma ampla dimensão na comunidade de jogos, simulações e animações, dentre outras.

Para a implementação desse tipo de tecnologia passou a ser necessário o inter-relacionamento entre áreas como: Vida Artificial, Realidade Virtual, Computação Gráfica, Inteligência Artificial, Ciência Cognitiva, Neurociência, Psicologia, Filosofia e Semiótica.

É nesse sentido que esta pesquisa procura esboçar uma abordagem capaz de ponderar a contribuição e a participação de alguns dos segmentos destacados, 
reforçando os enfoques da pesquisa que se estruturam sob Vida e Inteligência Artificial e ainda a Realidade Virtual.

O problema a ser abordado é descrito na seqüência. Após a apresentação do objetivo e a motivação da pesquisa, o texto explora uma proposta da dissertação para desenvolver essa linha estabelecida até então. Depois é delineado um quadro formado pelas contribuições desse trabalho e encerrando este tópico, a organização do restante do texto.

\subsection{Problema Abordado}

Na década de 80, a vertente das pesquisas relacionadas a Agentes e Sistemas MultiAgentes iniciou um processo de redefinição e enquadramento dentro da IA, o que resultou em um novo paradigma de programação: a Orientada a Agentes (Bond, 1988) (Fernell, 1977) (Hewitt, 1977).

Um segmento da IA e dispositivo fundamental ao pleno exercício de um agente é o mecanismo que toma as decisões. Tal mecanismo, antes de escolher uma alternativa dentre um universo possível, baseia-se em informações observadas no ambiente externo e também em mecanismos internos.

As informações obtidas são passíveis de ruídos ou interpretações errôneas, uma vez que os agentes normalmente apresentam uma margem de erro, o que interfere e acaba comprometendo o processo de tomada de decisão do agente, em outras palavras, falta de conhecimento correto e completo do mundo externo.

Os agentes, além da necessidade de lidar com essa margem de "ignorância" que reside nas informações, podendo ser tratada aqui como imprecisa e vaga, também enfrentam um outro problema, o caráter dinâmico. Na maioria dos casos os ambientes apresentam uma dinâmica que degrada ou até invalida o comportamento desenvolvido pelo agente. Para esse caso, os agentes precisam estar hábeis a perceber mudanças significativas que exijam um melhor desempenho.

Para trabalhar a questão destacada, os agentes seriam obrigados a eles próprios se alterarem ou, em casos extremos, até se reconfigurarem (sua estrutura) para atuar eficientemente. Tal processo, que se inicia na detecção da necessidade de 
se alterar até a real alteração e posteriores correções, reforça a interligação do assunto com aspectos de adaptação do agente.

\subsection{Objetivo}

A pesquisa toma como base os dois principais problemas de agentes destacados anteriormente (habilidades em manipular informações imprecisas e incertas e a adaptação ao meio). Assim, o foco da pesquisa é direcionado com o intuito de agregar uma solução aos problemas abordados até então, que estão melhor relatados na seqüência.

Uma possível interface entre o agente e o ambiente é constituída pelo processo de percepções e por um conjunto de estímulos. As informações recebidas pelo agente têm a finalidade de garantir a ele uma representação pessoal do meio externo, ou seja, o ambiente pelo qual esteja envolvido. Para isso, cabe ao agente interpretar essas informações e reproduzir um conhecimento apropriado. Contudo, justamente pela parcialidade das informações e pela sua interpretação é que está suscetível a falhas e ruídos, acarretando no surgimento de incertezas no sistema.

A situação descrita representa basicamente o principal alvo a ser trabalhado. A pesquisa tem por objetivo geral contribuir com a forma que o agente lida com esse tipo de informação. O trabalho pretende desenvolver um modelo de comportamento para uma especialização de agentes, os humanos virtuais autônomos ${ }^{1}$, capaz de promover:

A construção de conhecimento e a capacidade de inferir com base em informações parciais;

A interação com o ambiente de modo autônomo e eficiente, com vistas para alguns aspectos como a evolução e o aprendizado;

A promoção de um estreitamento entre as áreas de Realidade Virtual, Inteligência e Vida Artificial;

\footnotetext{
${ }^{1}$ Humanos Virtuais Autônomos: de modo extremamente sintético, poder-se-ia descrevê-los como agentes normais se não fosse pelo forte apelo gráfico, ou seja, esses agentes possuem uma representação gráfica tridimensional e um comprometimento tanto da representação quanto do agente em ter um comportamento semelhante ao de um ser humano real.
} 
A reprodução, sob o contexto de Vida Artificial e de modo simplificado, da cognição humana sob aspectos gerais, e em particular o processo racional para tomar uma decisão, mediante observações do cenário local;

A recriação de um experimento de cunho social com o intuito de demonstrar uma sociedade humana e a sua fragilidade sob determinados aspectos de origem interna.

\subsection{Motivação}

A pesquisa foi sendo contextualizada através de trabalhos desenvolvidos por alguns grupos de pesquisa com forte aderência com a abordagem pretendida, tais como o MIRALab (2006) e o VRLab (2006), ambos comprometidos com o desenvolvimento de ambientes virtuais tridimensionais através das tecnologias de Realidade Virtual e Realidade Aumentada, que constitui uma extensão da primeira. Atrelado a esse desenvolvimento, suas pesquisas são caracterizadas por implementações de Humanos Virtuais, incluindo comportamentos sociais e a sua integração com o escopo de Vida Artificial, que sintetizam muito bem a frente de atuação destes laboratórios, cujos trabalhos sempre alcançaram grande repercussão.

Outra fonte de influência foi o CROMOS (2006) que atenta para simulações com um grande número de Humanos Virtuais em um ambiente limitado espacialmente, representando assim, grandes densidades demográficas (Musse, 1997), (Musse, 2001a), (Musse, 2001b). Tais simulações são o resultado de pesquisas referentes ao comportamento social e às influências sofridas por ruídos do meio, sobretudo os causadores de pânico e ocasiões de emergência.

Fugindo um pouco do escopo de humanos virtuais e observando os resultados obtidos em simulações dotadas de personagens e estruturas mais simples, destacamse os trabalhos de Terzopoulos (2006). Suas pesquisas concentram-se na aplicação das técnicas de Vida Artificial em Computação Gráfica, com destaque para animações de personagens. Suas publicações tratam de aprendizado e sensoriamento de alguns animais, como a clássica dinâmica presa/predador, que é representada por peixes em seus trabalhos. 
Ainda nessa linha, a pesquisa se relaciona também com os projetos incubados pelo ARTLIFE (2006) (Cognitio, 2006). Estes trabalhos serviram de apoio na especificação de um framework que descrevesse o comportamento dos personagens, além de ajudarem na contextualização dentro do escopo de Vida Artificial (Netto, 2006). Enquanto o Projeto do WOXBOT (Miranda, 2001) está direcionado ao caráter evolutivo e manipulação de genes, o ALGA (2006) lida com o processo de aprendizado através do contato social, e já o ALIVE (2006) propõe uma plataforma de auxílio em experimentos destinados a área. Assim, o presente projeto denominado de V1V0 lida primariamente com a manutenção do conhecimento levando-se em consideração o fator da incerteza, sendo, mais tarde, esse conhecimento empregado em um processo de tomada de decisões.

\subsection{Proposta}

A proposta da pesquisa é desenvolver um modelo de comportamento que seja capaz de representar e posteriormente inferir sobre um ambiente mesmo havendo margens de relativa incerteza.

Sob esse intento, o trabalho decorre de uma abordagem pautada principalmente pela área de Vida Artificial. Essa abordagem contempla ainda outras áreas significativas como Inteligência Artificial, Realidade Virtual e até mesmo a Ciência Cognitiva.

Desta forma em Vida Artificial são tratados os aspectos relacionados ao comportamento social e em Inteligência Artificial ao raciocínio de inferência em situações incertas. O modelo proposto é especialmente voltado para humanos virtuais cuja validação é obtida através de algumas regras que delimitem uma simulação de testes. Assim, a simulação pretendida permite avaliações e novos reenquadramentos do projeto. 


\subsection{Contribuições}

O desenvolvimento da pesquisa almeja contribuir com a comunidade cientifica de modo que as principais áreas abordadas sejam as maiores beneficiadas. Dentre alguns dos benefícios que poderão ser atingidos, cabe destacar:

- Ampliação do aspecto relativo à adaptação e autonomia de agentes;

- Desenvolvimento de uma concepção de modelo de comportamento que permita ao humano virtual interagir de modo eficiente. Sendo assim, esse modelo pode ser aplicado a personagens de jogos, experimentos de Vida Artificial e Realidade Virtual que necessitem de personagens autônomos;

- Representação das informações geradas pelos personagens, planejadas de modo a permitir a manipulação de modo a se considerar o nível de incerteza associado, tornando o sistema mais robusto, uma vez que este esteja preparado para tomar decisões levando-se em conta possíveis riscos;

- Comportamento emergente sob o aspecto de maturidade, que pode ser reflexo dos ajustes dos níveis de certeza associados às informações por parte dos humanos. Essa característica facilita os esforços de engenharia que costumam ser aplicados durante a concepção e desenvolvimento de projetos, pois estes são capazes de agregar novas informações que inicialmente não haviam sido previstas pelos projetistas;

- Construção de projeções e estimativas cuja calibração possa ser corrigida ao longo dos acontecimentos devido ao processo de inferência;

- Ratificação de um processo de decisão comprometido com o sistema de inferência, aonde o êxito dessas ações venham a servir como parâmetros para a manutenção do mecanismo de inferência empregado; 
- Exploração de técnicas (Realidade Virtual) que propiciem melhores experiências em simulações de Vida e Inteligência Artificial;

\subsection{Estrutura da Dissertação}

O texto escrito para apresentar a presente pesquisa está estruturado em quatro partes principais. Na primeira parte estão reunidos de modo sintético os principais conceitos relacionados a um comportamento autônomo sob o contexto de Vida e Inteligência. $\mathrm{Na}$ segunda parte, são trabalhados assuntos pertinentes a representação gráfica de tudo o que possa estar envolvido ao âmbito de comportamento de personagens.

$\mathrm{Na}$ seqüência, as especificações e a proposta do modelo de comportamento são detalhadas de modo mais minucioso. Ainda nessa parte, ocorre a apresentação de um possível cenário modelado para avaliar o presente modelo de comportamento. $\mathrm{Na}$ quarta parte seguem os resultados preliminares desse ato empírico. Encerrando o conteúdo principal da dissertação, as considerações finais encaminham as atuais constatações e dando continuidade a essa pesquisa, os trabalhos futuros. 
2 VIDA E INTELIGÊNCIA ARTIFICIAL

"A coisa mais importante a se lembrar sobre Vida Artificial é que a parte artificial não é a vida, mas os materiais. Coisas reais acontecem. Fenômenos reais são observados. É vida real em uma mídia artificial" [Christopher Langton]. 


\subsection{Vida Artificial}

A área de Vida Artificial (VA), concentra pesquisas relacionadas a conceitos associados à vida, com o propósito de melhor compreendê-la. Neste sentido pode-se perceber a relevância substancial do processo empírico, bem como da utilização de modelos biológicos e matemáticos para realizar simulações computacionais adequadamente concebidas para demonstrar alguns dos inúmeros aspectos de vida.

Talvez uma das melhores descrições do termo VA decorra da sinergia entre três grandes frentes de estudo: a Biologia, a Matemática e a Computação.

Ao se analisar a influência que a Biologia exerce sobre a VA, é possível concluir que ela se propõe como o próprio objeto do estudo da área. Assim sendo, o conhecimento gerado pela ciência dos fenômenos da vida, que são orquestrados por regras gerais, alimenta essas pesquisas.

A Matemática contribui com o manuseio preciso e formal das informações, números, regras e fluxo dos sistemas naturais e artificiais. É através dessa ciência que são construídos os modelos, estudadas as relações entre os objetos, proporcionando o amparo teórico ao processo empírico.

O empirismo, que muito auxilia na compreensão dos estudos biológicos, tem o seu desenvolvimento favorecido pela Computação. Serve, assim, de base metodológica para as simulações das mais diversas características (Adami, 1998).

Atualmente pode-se dizer, de uma forma mais abrangente, que "the term Artificial Life is used to describe research into human-made systems that possess some of the essential properties of life" (Adami, 2000) ${ }^{2}$. Adami ainda completa a sua descrição relacionando o tema com pesquisas cujo enfoque sejam: o estudo da vida na Terra, sistemas auto-organizáveis, comportamento social e emergente, além de considerações sobre que outras formas a vida poderia manifestar, que explora a síntese de vida em um substrato de silício.

2 Tradução do autor: "o termo Vida Artificial é usado para descrever a pesquisa nos sistemas desenvolvidos pelo homem que possuem algumas das propriedades essenciais da vida". 


\subsubsection{Fenômenos Observados em Vida}

Talvez uma outra forma de abordar os conceitos envolvidos em VA seja tratando dos fenômenos observados. Dessa maneira, fenômenos como reprodução e evolução, desenvolvimento, adaptação e aprendizado, além do comportamento social, podem ser observados empiricamente e comparados com resultados decorrentes de simulações estabelecidas sobre modelos representativos dos personagens analisados (Cavalhieri, 2005), (Netto, 2005a), (Netto, 2005b), (Rodrigues, 2006).

A reprodução, cujo intuito maior é a perpetuação das espécies, se atém à conservação das informações que descrevem o grupo biológico no qual ocorre. A preservação dessas informações deve se estender ao longo das gerações. No entanto, as espécies estão sujeitas a ruídos e perturbações do meio, o que pode resultar em transformações com o objetivo de especializar e tornar a espécie melhor preparada, o que caracteriza a evolução.

O processo de desenvolvimento do indivíduo constitui todo o período de vida, havendo uma segmentação em duas fases distintas. A primeira fase é o período embrionário (pré-natal), onde a estrutura genética desse ser é decodificada e como consequiência, o mesmo é formado fisicamente com base em seu material genético. A segunda e última fase é destacada como pós-natal e compreende reestruturações que vão além do caráter físico, como a adaptação e o aprendizado.

O mecanismo de adaptação permite aos melhores ajustados, para uma certa situação (ambiente em que vivam), poderem perpetuar tal capacidade através da reprodução, quando o material genético que carregam é propagado para novas gerações.

O aprendizado, por sua vez, se caracteriza como a habilidade do ser em armazenar um determinado conhecimento que não lhe havia sido previamente atribuído. Uma outra característica do aprendizado é a sua aderência com o registro histórico, que refletem a experiência e a maturidade do ser que vigora em função de seu tempo de vida no ambiente. Tal habilidade pode ocorrer de três formas principais: por observação, por exploração ou por ensinamento, o que compreenderia todo um protocolo social em decorrência do processo ocorrer baseado na comunicação entre dois ou mais seres. 
O comportamento social, por sua vez, pode ser tratado a partir da avaliação de parâmetros e de seus mecanismos de manipulação para apoiar a integração entre os seres, o que resulta em ações coletivas ou emergentes. A ocorrência desse tipo de comportamento é fortemente dependente da capacidade de comunicação, podendo também se beneficiar de suportes decorrentes de outras áreas da computação, como é o caso da Inteligência Artificial: objetivos, planejamento e convencimento, dentre outros.

\subsubsection{Classificação de Projetos em Vida Artificial}

A síntese do cenário descrito é estudada em suma por duas ciências: a Filogenia ${ }^{3}$ e a Filogênese. Enquanto a primeira se ocupa do estudo da sucessão genética das espécies ao longo das gerações, a segunda ocupa-se do processo de criação e formação da espécie. Portanto podemos dizer que a Filogenia estuda a manutenção genética das espécies e a Filogênese o surgimento da nova espécie. Saindo da abrangência da espécie (filo) e direcionando a fonte de pesquisa para o indivíduo ou para o ser (onto), os fenômenos que são compreendidos pelo ciclo de vida de um determinado ser vivo são acompanhados pela Ontologia ${ }^{4}$ e pela Ontogênese $\mathbf{O}^{5}$.

Na Ontologia são destacadas as características mais gerais do ser vivo, pois esta área da filosofia e ciência concentra-se em estudá-lo e descrevê-lo. Já a Ontogênese acompanha a série de transformações sofridas pelo ser, da concepção à velhice. Esse ciclo de amadurecimento pode ser divido em duas fases: a Pré e a PósNatal. No primeiro é tratada pela embriologia, abrangendo desde o período de fecundação até o nascimento, enquanto que a segunda se estende até a morte do ser.

\footnotetext{
${ }^{3}$ Filogenia: história evolutiva de uma espécie ou qualquer outro grupo taxonômico; filogênese, filogenesia (Houaiss, 2001).

${ }^{4}$ Ontologia: segundo o aristotelismo, parte da filosofia que tem por objeto o estudo das propriedades mais gerais do ser, apartada da infinidade de determinações que, ao qualificá-lo particularmente, ocultam sua natureza plena e integral; metafísica ontológica (Houaiss, 2001).

${ }^{5}$ Ontogênese: o desenvolvimento de um indivíduo desde a concepção até a idade adulta; ontogênese (Houaiss, 2001).
} 
Complementando essas duas vertentes de estudo de Vida Artificial - a Filo e a Onto -, a Epistemologia ${ }^{6}$, que promove a ciência do conhecimento, lida com situações de inteligência. Embora a manutenção do conhecimento possa ocorrer mesmo nas situações nas quais os seres sejam desprovidos de características inteligentes, são nas estruturas passíveis de comportamento inteligente que a ciência do conhecimento é altamente relevante.

Juntamente, a Epistemologia, a Ontogenia (e Ontogênese), e mais a Filogenia (e Filogênese), são capazes de descrever um espaço tridimensional, onde cada eixo corresponde a uma destas três componentes (Figura 1). Este espaço serve então para classificar um dado projeto na área de VA. Assim podemos, por exemplo, considerar o eixo X como descrevendo a intimidade do projeto com estudos voltados ao caráter do ser enquanto indivíduo (Ontogenia e Ontogênese); o eixo Y por sua vez, a intensidade enquanto espécie (Filogenia e Filogênese); e o eixo $\mathrm{Z}$ o comprometimento com o conhecimento (Epistemologia).

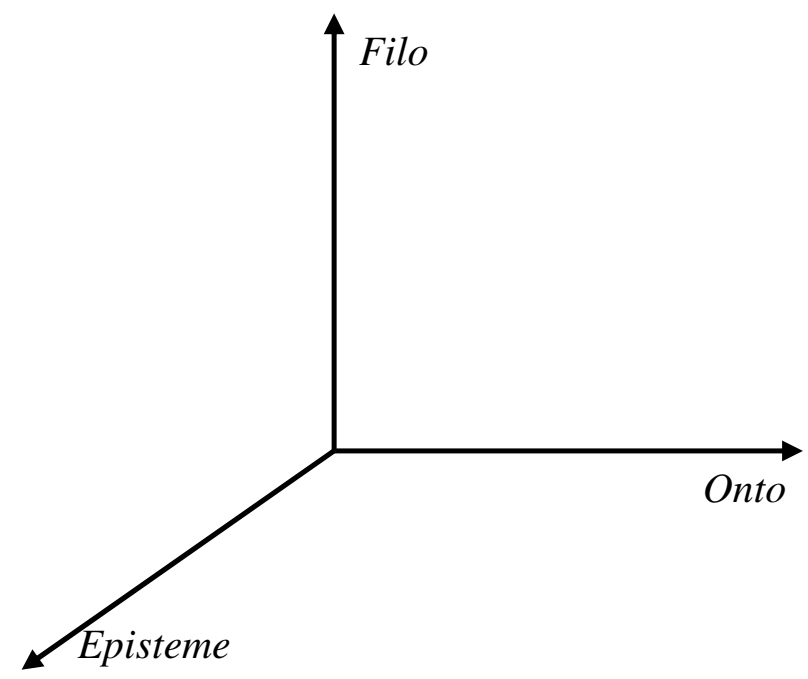

Figura 1: Espaço tridimensional de VA formado pela tríade: Filo, Onto e Episteme.

O relacionamento entre essas três concepções de observação e análise de projeto (Filo, Onto e Episteme) permite contextualizar de modo espacial com Vida Artificial qualquer trabalho ou pesquisa que apresente algum tipo de familiaridade

\footnotetext{
${ }^{6}$ Reflexão geral em torno da natureza, etapas e limites do conhecimento humano, esp. nas relações que se estabelecem entre o sujeito indagativo e o objeto inerte, as duas polaridades tradicionais do processo cognitivo; teoria do conhecimento (Houaiss, 2001).
} 
com os conceitos explorados. Assim, torna-se mais objetiva e clara a percepção do comprometimento da pesquisa com o caráter evolutivo, adaptativo, técnicas de aprendizado, interatividade social e emersão do conhecimento.

\subsubsection{Principais Trabalhos e Simulações}

Um trabalho de grande destaque em VA é o de Karl Sims (Sims, 1994) (Sims, 2006). Ele se destaca pelo caráter evolutivo (teoria Darwiniana) desenvolvido pela espécie considerada. Seus trabalhos se baseiam em personagens representados por estruturas geométricas, e que habitam um ambiente virtual gerido pelas leis gerais da Física (Figura 2).
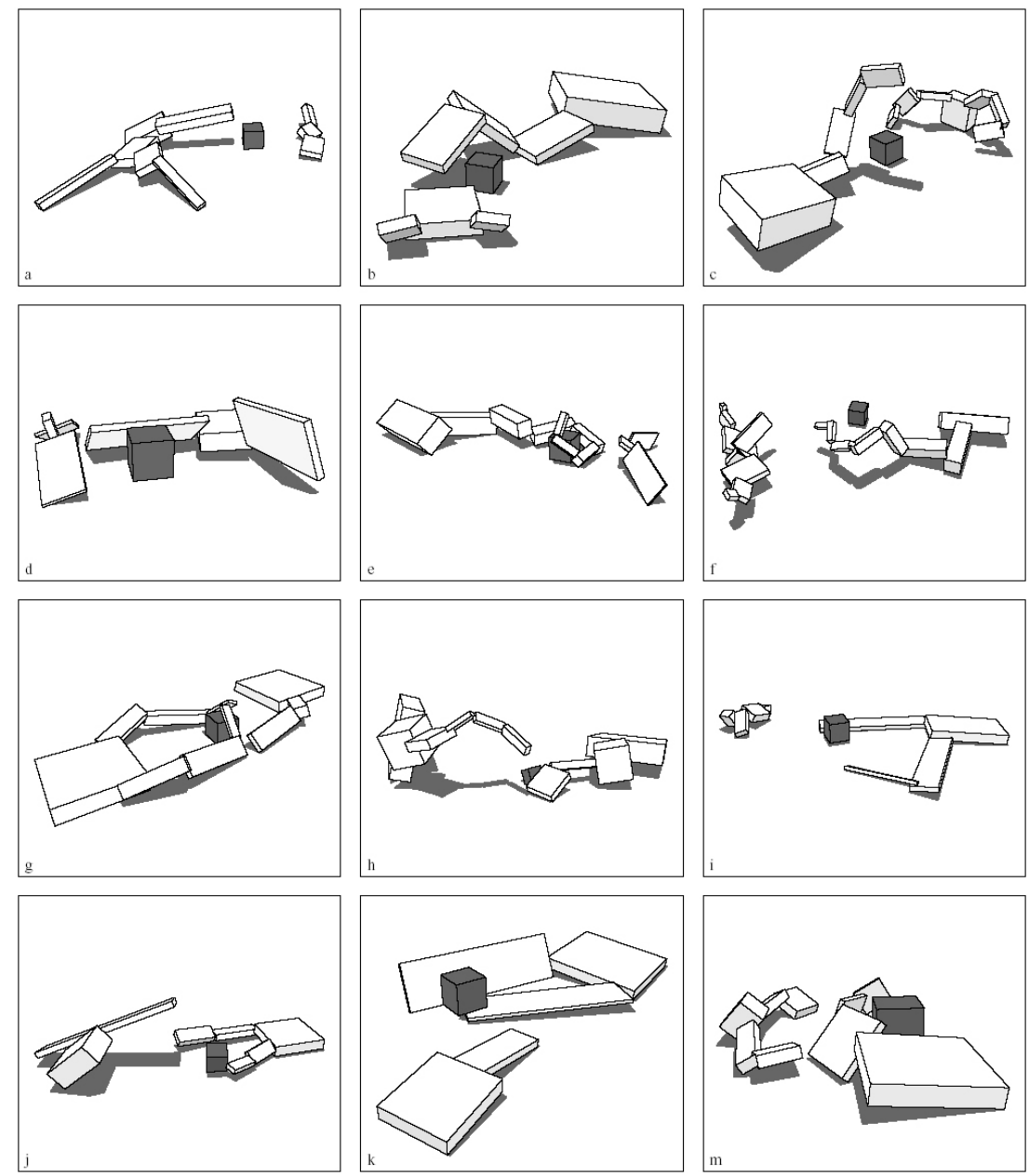

Figura 2: Evolução de seres compostos por estruturas primárias (Sims, 2005).

As estruturas tridimensionais evoluem e se adaptam de modo a procurar disposições mais convenientes de suas articulações para melhor se locomover ou 
desempenhar funções que sejam relevantes para seu sucesso nas competições em que venham a participar. É interessante ressaltar que esses trabalhos também contribuem significativamente para a área de Computação Gráfica, pois a animação desses personagens é conseguida como produto final do processo evolutivo.
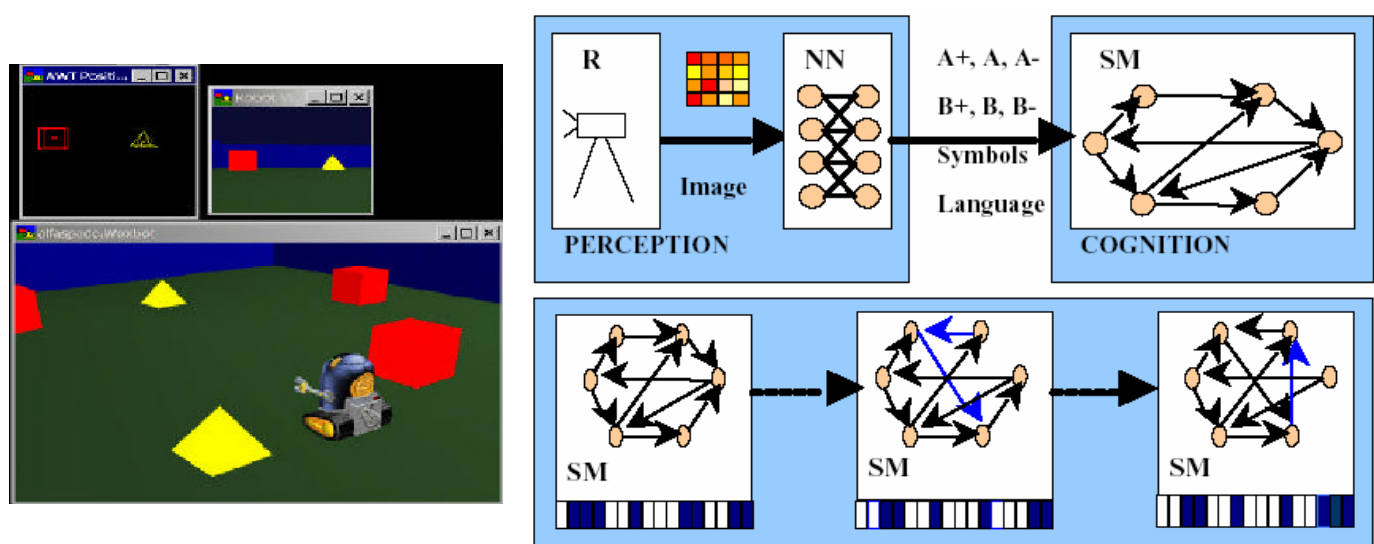

Figura 3: WOXBOT e o processo evolutivo ao longo das gerações (Miranda, 2001).

Outro trabalho que segue essa mesma linha de evolução do filo é o projeto WOXBOT (Miranda, 2001). Essa pesquisa incubada no grupo ArtLife é composta por um personagem virtual que tem os seus genes alterados ao longo das gerações por Computação Evolucionária (Figura 3). Os genes abordados codificam como o personagem irá atuar no ambiente, sabendo-se que ele precisa otimizar seu desempenho para sobreviver e assim ter seu sucesso reprodutivo aumentado.

Migrando para a outra vertente do conceito de VA, os trabalhos relacionados ao estudo do ser enquanto indivíduo (Ontogenia e Ontogênese) de Demitri Terzopoulos são referenciados tanto pela sua forte aderência com o escopo de pesquisa quanto pela sua integração com a área de animação comportamental em computação gráfica (Figura 4) (Terzopoulos, 1999), (Terzopoulos, 2006).

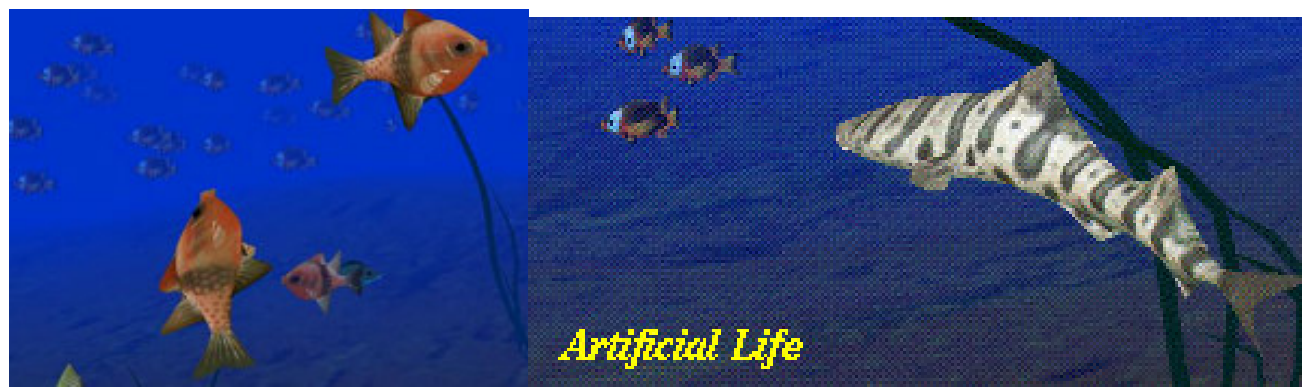

Figura 4: Simulações de Vida Artificial com peixes e dinâmica Presa-Predador. 
Seguindo essa abordagem de pesquisa, o projeto ALGA lida com peixes virtuais que desenvolvem aspectos relacionados à capacidade de aprendizado (Netto, 2004). Os peixes buscam sobreviver num ambiente competitivo, onde um bom comportamento cognitivo e social implica diretamente no sucesso ou fracasso desses personagens que aprendem uns com os outros por interação social.

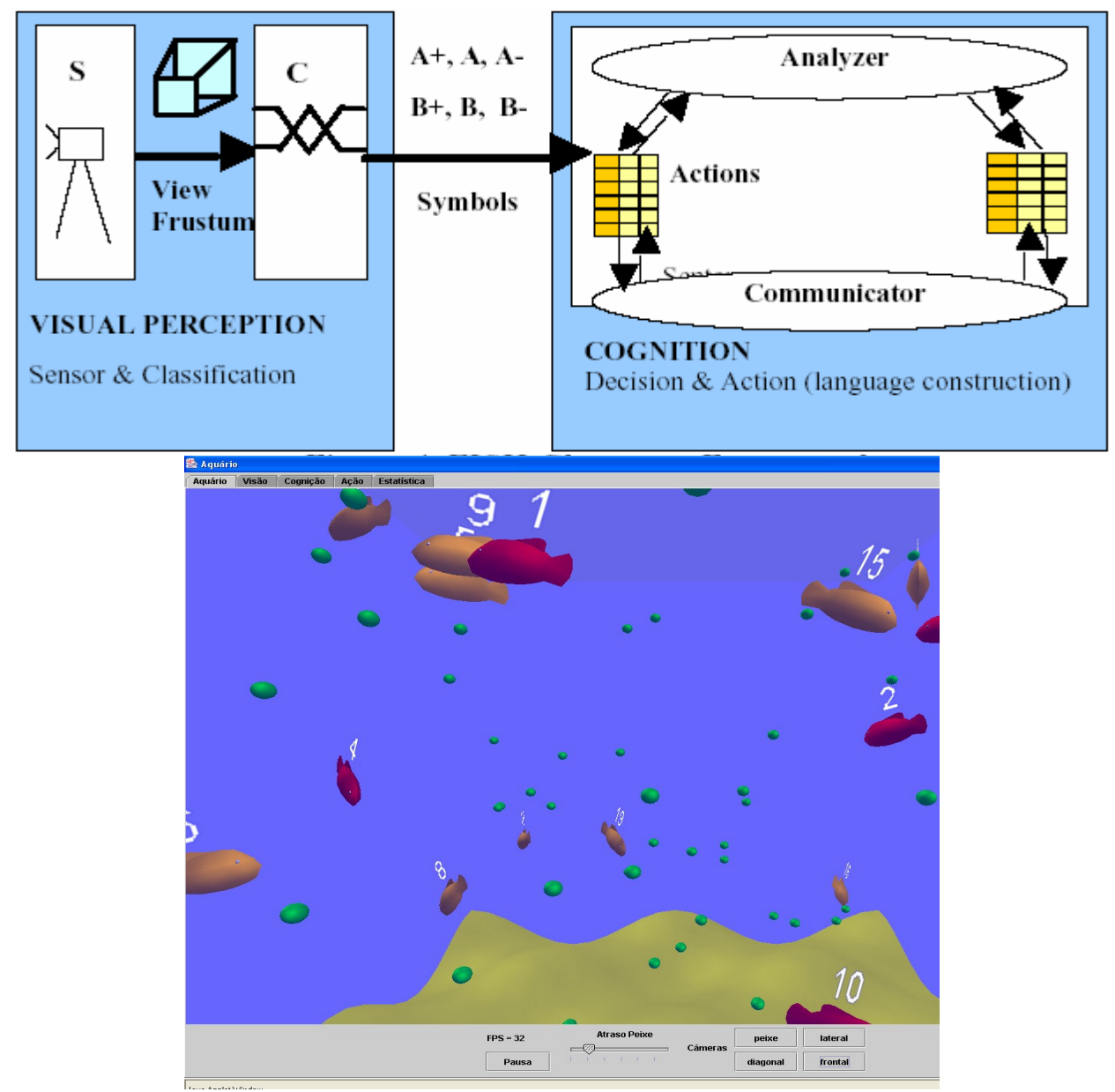

Figura 5: ALGA e a arquitetura que descreve o comportamento dos peixes (Netto, 2004).

Em outro segmento estão as pesquisas que relacionam aspectos de inteligência, cognição, aprendizado através de parâmetros mais elaborados, comportamento social e emergente; obtidos por meio de grandes densidades demográficas (multidões) (VRLab, 2006), (Musse, 1997), (Musse, 2001a), (Musse, 2001b). Esta abordagem de VA envolve simulações de comportamento humano, que será melhor abordada nos capítulos posteriores, e é denominada de humanos virtuais autônomos (Thalmann, 1994). 


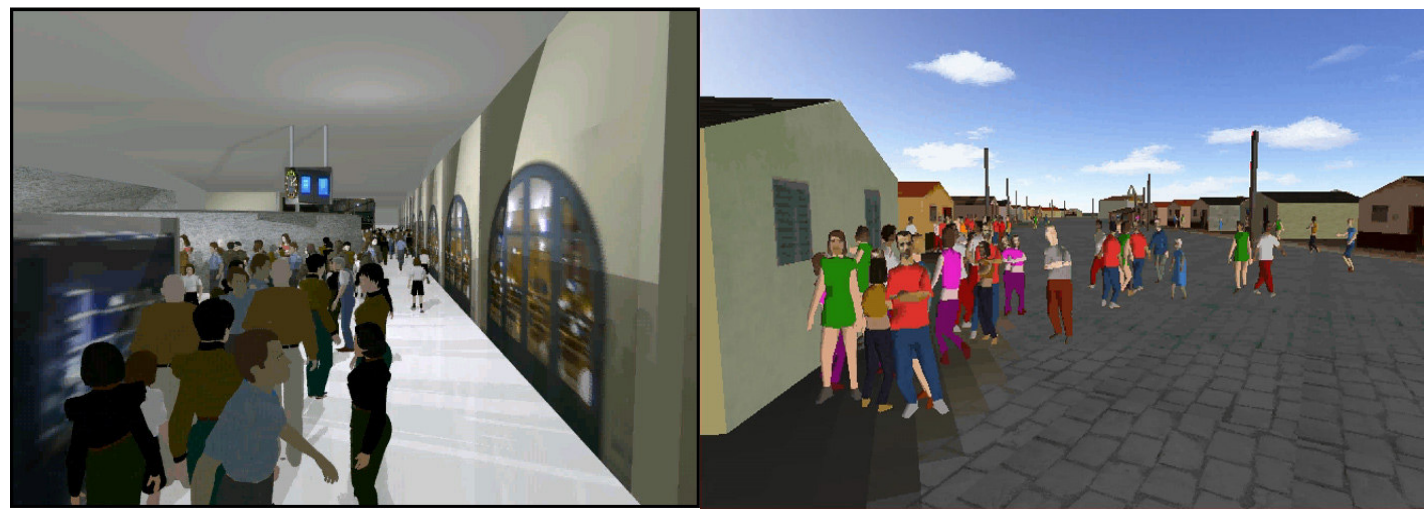

Figura 6: Simulação de multidões integradas por Humanos Virtuais (Musse, 2006).

\subsection{A Inteligência Artificial como Ferramenta}

O termo Inteligência Artificial foi cunhado pela primeira vez em 1956, após a Segunda Guerra Mundial, e teve seus trabalhos financiados pelo propósito bélico durante toda a Guerra Fria. A Inteligência Artificial, que possui inúmeras definições e abordagens, foi fortemente influenciada pelo teste proposto por Alan Turing (1950) - o Teste de Turing (Bittencourt, 2001).

Essa influência pode ser descrita pelas capacidades que o computador a ser atestado pelas especificações de Turing necessitaria ter: processamento de linguagem natural, representação do conhecimento, raciocínio automatizado e aprendizado de máquina. Em decorrência da participação desse teste na IA surgiram duas tendências na área que foram apelidadas de IA Forte e Fraca.

A IA Forte é concebida através da idéia de que sistemas podem ser capazes de atuar como seres humanos, enquanto que na Fraca os sistemas apenas desenvolvem a racionalidade - também presente na inteligência humana.

A Inteligência Artificial e a Ciência Cognitiva se fundem ou ao menos se aproximam consideravelmente pela corrente da IA Forte, o que acaba servindo como uma poderosa ferramenta para o processo empírico da Ciência Epistemológica. Assim, a Ciência Cognitiva desenvolve a modelagem do ato humano denominado pensamento e a IA o reproduz digitalmente. Contudo, a IA Fraca através da racionalidade pauta o acervo de ferramentas com as leis do pensamento, que são o raciocínio lógico. 
Independentemente da tendência, a IA é fundamentada sobre a Filosofia, a Linguiística, a Psicologia, a Neurociência, a Ciência Cognitiva, a Matemática e a Computação, e se propõe a reproduzir ou solucionar situações que exijam demonstração de inteligência.

\subsection{Sistemas de Agentes}

Na sua definição mais simples, Russell (2004) destaca que "um agente é tudo o que pode ser considerado capaz de perceber seu ambiente por meio de sensores e de agir sobre esse ambiente por intermédio de atuadores". Embora essa definição seja muito abrangente, ela apresenta de modo simples a idéia de agentes.

Uma outra definição, um pouco mais precisa é a de Wooldridge (1999) onde "um agente é um sistema de computação que é capaz de agir independentemente (autônomo) de um usuário...”. Aprimorando essa definição seria interessante frisar que o agente segue um propósito ou objetivo para que suas ações modifiquem o ambiente de acordo com as suas necessidades.

Como já mencionado anteriormente, os sensores e os atuadores são fundamentais ao agente, uma vez que eles desempenham o papel de interface com o ambiente. Essa interface garante ao agente a capacidade de se comunicar com o ambiente, e desta forma desempenhar internamente procedimentos condizentes com a realidade externa. Para tratar essa comunicação, seja para avaliar as informações vindas do ambiente, seja para produzir outras destinadas ao meio externo, os agentes possuem uma estrutura que responde pelo seu comportamento (Weiss, 1999) (Wooldridge, 2002).

\subsubsection{Framework do Comportamento de Agentes}

Uma forma clássica de apresentar e descrever o comportamento de um agente é segmentando-o em Percepção, Cognição (Inferência) e Atuação (Figura 7), (Huhns, 1998). Conforme o propósito para o qual o agente foi criado, alguns destes segmentos podem ser melhor desenvolvidos. 
A Percepção trata o conjunto de entradas que funcionam como sensores do agente. Estes sensores extraem informações sobre o ambiente e as codificam para serem manipuladas internamente pela cognição. O conhecimento da seqüência de percepções é útil, pois ela é um dos parâmetros para a escolha de uma ação pelo agente, que normalmente observa um breve histórico do ambiente para depois poder manipulá-lo.

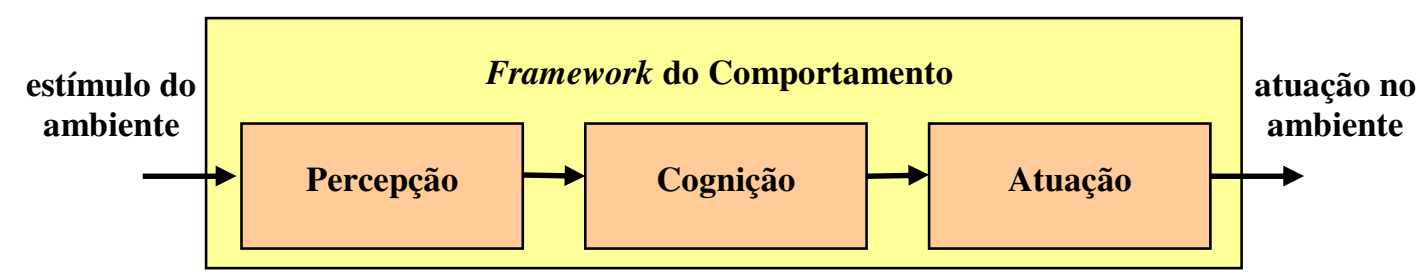

Figura 7: Esquematização dos módulos responsáveis pelo funcionamento de um agente.

A percepção transforma informações obtidas sensorialmente (imagens, sons) em objetos simbólicos, ou seja, que carregam consigo certos conceitos, que podem ser apropriadamente tratados pela cognição para realizar inferências lógicas e assim determinar ações que serão passadas para o módulo subseqüente.

O módulo responsável pelo tratamento dessas informações, a Cognição, é capaz de mapear qualquer seqüência de percepções para uma determinada ação. Esse mapeamento é denominado função do agente, que de modo geral descreve o modo de seleção das ações. O comportamento é decorrente deste processo, na medida em que consiste na seqüência de ações, executadas a partir de decisões tomadas pelo agente.

Já a Atuação, resume-se em operar os atuadores de modo a cumprir a ação determinada pela Cognição, interagindo assim com o ambiente. Os atuadores por sua vez desempenham o papel de interface de saída entre o agente e o meio externo.

\subsubsection{Desempenho e Racionalidade de Agentes}

O desempenho dos agentes pode ser constatado de várias formas, observando assim a eficácia do modelo comportamental desenvolvido. No entanto, qual seria o verdadeiro conceito envolvido em um bom desempenho de um agente? 
$\mathrm{Na}$ literatura é possível encontrar algumas considerações significativas com relação ao desempenho e a racionalidade desses agentes. Russell (2004) aponta como agente racional, aquele que é capaz de realizar inferências, com o que pode, no tempo de que dispõe para tal, tomar decisões substanciadas por uma melhor capacidade de análise de cenários. Embora em algumas situações um comportamento rotineiro possa ser satisfatório, agentes que não possuam uma capacidade de raciocínio mais elaborada normalmente ficam limitados quanto às suas potencialidades. Cenários dinâmicos, por exemplo, requerem dos agentes uma capacidade de análise que não existe numa simples reação pré-determinada.

Caso o agente tivesse a oportunidade de explorar melhor as ferramentas de que dispõe para alterar os estados do ambiente, talvez pudesse descobrir melhores formas de agir de acordo com a sequiência de percepções, ou então, reforçaria que a melhor ação era a que ele estava acostumado a realizar. Esse artifício de experimentação pode ser promovido por um tom ponderado de aleatoriedade, sendo esse zelado pela racionalidade. Assim a racionalidade pode ser vista como a capacidade de avaliar cenários e tomar decisões que sejam potencialmente as que resultem em melhores resultados.

A racionalidade pode ser repassada ao agente pelo seu projetista, que leva em consideração quatro fatores:

- a medida de desempenho que define o critério de sucesso do comportamento;

- o conhecimento anterior que o agente tem do ambiente;

- as ações passíveis de serem executadas;

- a seqüência de percepções até o momento.

Mas a racionalidade pode também ser uma decorrência espontânea, situação na qual seu desenvolvimento segue estratégias evolutivas. Dada a dificuldade de se conseguir resultados esperados, ou mesmo a baixa probabilidade de que racionalidades interessantes venham a emergir, esta prática nem sempre é considerada. Porém em alguns casos pode levar a bons resultados, como comprova o 
projeto WOXBOT através de uma das linhas de pesquisa de Vida Artificial: a Computação Evolutiva ${ }^{7}$ (Miranda, 2001).

Uma definição mais elaborada da influência desses fatores sobre a racionalidade de um agente pode ser: "para cada seqüência de percepções possível, um agente racional deve selecionar uma ação que se espera venha a maximizar sua medida de desempenho, dada a evidência fornecida pela sequiência de percepções e por qualquer conhecimento interno do agente" (Russell, 2004).

\subsubsection{Tópicos de Racionalidade}

A relação direta entre racionalidade e conhecimento acaba levantando a alguns tópicos pertinentes à abordagem de agentes, e que são: a Onisciência, o Aprendizado e a Autonomia.

No caso da onisciência, esta se distingue sutilmente do caráter racional por implicações entre o esperado e o real. Enquanto um agente onisciente conhece o resultado real de sua atuação, o racional desenvolve uma expectativa através do resultado esperado em decorrência de sua própria atuação. Em outras palavras, a racionalidade procura melhorar o desempenho esperado, já a onisciência trabalha diretamente com o desempenho real.

Mesmo que possa parecer mais atraente a idéia da onisciência, que possibilita ganhos reais ao desempenho do agente, para casos práticos é quase impossível se projetar um agente que atenda a tais especificações. Dessa forma, demonstra-se a grande importância dos agentes racionais, que mesmo sem possuir um projeto amplo e abrangente, são capazes de buscar melhorias através de suas expectativas.

Um dos recursos empregados para o alcance dessas melhorias é a coleta de informações e a exploração de um ambiente pouco conhecido. Esses recursos mostram o compromisso do agente com a sua atuação futura, uma vez que ele busca mais informações para tomar melhores decisões no futuro.

\footnotetext{
${ }^{7}$ Computação Evolutiva: linha de pesquisa em Vida Artificial que concentra seus esforços no escopo de Filogenia (preocupação com as informações enquanto espécie) e para isso, é influenciada pelas teorias de Darwin e as leis da genética de Mendel.
} 
Essa busca por informações adicionais, que complementem o seu conhecimento a priori, atribui ao agente a capacidade de aprendizado. A atribuição de aprendizagem é uma tarefa de manipulação do nível cognitivo do agente, e é composta por algumas fases distintas.

Uma fase inicial compreende a construção da estrutura desse agente. Esta fase, em que o projetista define o agente e lhe atribui códigos para diferentes situações, é seguida pela fase de criação, quando o agente é instanciado e devidamente inicializado conforme as especificações de projeto.

Já a fase de vida do agente, que é subseqüente a de criação, pode ser descrita a partir do momento em que este começa efetivamente a ser executado. Desta última podem ainda fazer parte etapas diferenciadas pela sua capacidade cognitiva.

Agentes que tenham capacidade de aprendizado podem ser, numa primeira etapa desta última fase bastante primitivos, pois ainda não adquiriram o conhecimento desejável. Contudo, podem ir melhorando em etapas subseqüentes, a partir do momento em que tenham atingido certos níveis de conhecimento em decorrência de seu aprendizado (Netto, 2004).

Numa última etapa os agentes podem até mesmo passar a conceber novos conceitos, ou propor novos paradigmas para suas ações. Estas diferentes etapas estão relacionadas às diferentes formas pelas quais o aprendizado pode ser desenvolvido, e que são por experimentação (iniciativa própria, avaliando o que é inerentemente conhecido), por reprodução (aprendido do contato com outros agentes), e por proposição (iniciativa própria criando novos conceitos).

Esse suporte inicial atribuído ao agente deve ser trabalhado com vistas à experiência e ao processo de aprendizado, servindo assim como uma ferramenta para um importante tópico em Vida Artificial: a Adaptação. Essa habilidade do agente em se basear não apenas no seu conhecimento inicial, mas também em suas próprias experiências constitui um dos mecanismos de adaptação. Essa adaptação em termos práticos propicia ao agente uma linha evolutiva de sua atuação, que tende a uma curva ascendente conforme sua experiência aumenta. 


\subsubsection{Propriedades dos Ambientes em IAD}

$\mathrm{O}$ ambiente ao qual o agente pertence e interage está fortemente relacionado com a área de aplicação, pois é no ambiente que estão as principais propriedades do domínio do sistema. As propriedades compreendem situações que permitem, por exemplo, ao agente estar em pleno contato com o ambiente, ou ainda, que este ambiente seja manipulado por um conjunto de agentes.

A especificação desses ambientes pode contribuir para a simplificação desse tipo de tecnologia. Assim sendo, tem-se as seguintes dimensões dos possíveis ambientes: Completamente ou Parcialmente Observável, Determinístico ou Estocástico, Episódico ou Seqüencial, Estático ou Dinâmico, Discreto ou Continuo e Multi ou Monoagente (Russel, 2004).

Os Ambientes Completamente Observáveis permitem ao agente ter acesso ao estado completo do ambiente no qual se encontra, sendo tal acesso realizado pela interface estabelecida através dos sensores de que o agente dispõe. Já os Ambientes Parcialmente Observáveis decorrem do fato de que nem sempre isto é possível, como, por exemplo, quando há a ocorrência de ruídos, imprecisão por parte dos sensores ou falta de alguma informação tida como essencial para o funcionamento do comportamento, que não pode ser obtida pelo sensoriamento.

A princípio, quando o próximo estado do ambiente depende exclusivamente do estado atual e da ação executada pelo agente, classifica-se o Ambiente como Determinístico. Porém, quando a configuração dos estados, e por conseqüência das ações dos agentes, são definidas a partir de uma série de fatores, evidencia-se a presença da incerteza nesse processo. Tal incerteza, que influi diretamente no processo de execução dos agentes, está relacionada diretamente ao ambiente o que classifica o Ambiente como Estocástico. Complementando os ambientes estocásticos, o sistema é não determinístico quando a ação de um agente não é a única responsável pela alteração do estado do sistema, de modo que o agente não possa estimar o estado futuro exclusivamente a partir do conhecimento do estado atual e de sua ação. Já nas situações onde o próximo estado do ambiente é definido apenas pelo seu estado anterior, tem-se casos de Ambientes Estratégicos. 
A descrição anterior trata de ambientes Determinísticos e Estocásticos sob a ótica dos ambientes exclusivamente. No entanto, caso essa ótica seja alterada para o ponto de vista dos próprios agentes, cabe destacar que são Determinísticos os ambientes em que somente um agente atue. Para os casos onde exista mais de um agente atuando simultaneamente, nenhum dos agentes seria capaz de prever com certeza o próximo estado. Essa incerteza decorrente da imprevisibilidade do próximo estado qualifica os ambientes como Estocásticos.

Os Ambientes Episódicos se caracterizam por exigirem dos agentes ações instantâneas e que tenham efeito apenas naquele momento. Para os casos em que a ação do agente seja propagada e interfira assim, nas decisões futuras, tem-se os Ambientes Seqüenciais. Esse tipo de ambiente normalmente exige que os agentes possuam habilidades de planejamento para que previamente sejam estimadas as conseqüências de suas ações. Já um outro recurso solicitado é o uso de uma memória para que o agente seja capaz de se lembrar das ações tomadas anteriormente e assim, avaliar o impacto de suas ações.

Em alguns casos é necessário observar a relação que existe entre o período de atuação do agente, ou seja, o tempo gasto pelo processo e pelos mecanismos de atuação de que ele dispõe, e o estado ou situação do ambiente naquele determinado instante do início do ato. Esse tipo de situação é relevante, pois em algumas circunstâncias o ambiente pode se alterar, normalmente por fatores externos, e no final da atuação do agente o resultado pode não ser o esperado inicialmente; devido à alteração do estado do ambiente enquanto ocorria a deliberação por parte do agente.

Para esses casos, o agente precisa observar constantemente a situação do meio externo e deve-se atentar para o fluxo temporal. Ambientes com essa propriedade são denominados Dinâmicos, enquanto que aqueles que não a possuem recebem o nome de Estáticos. Uma outra classificação refere-se especificamente ao estado e ao tempo do Ambiente que pode ser Discreto ou Contínuo.

Por fim, uma outra característica dos ambientes está relacionada ao número de agentes, que são denominados de Mono-agente ou Multi-agente. As implementações que operem sob um projeto para Ambiente Multi-agente podem ter um caráter Competitivo ou ainda Cooperativo e devem possuir mecanismos de 
Comunicação bem desenvolvidos, para que tais cooperações (competições) possam ser melhor estabelecidas (Dorigo, 1996). É, no entanto, possível ter cooperação ou competição sem comunicação direta entre os agentes, mas apenas pela capacidade de observação do ambiente.

\subsubsection{Arquiteturas de Agentes}

Conforme Russell (2004), após verificar os tipos de influência que o meio externo exerce sobre os agentes é possível contextualizar os diversos gêneros de comportamento deliberados, que basicamente diferem pela estruturação do programa do agente, ou seja, a sua arquitetura.

Um comportamento bem simplificado é o empregado pelos agentes tidos como Reativos Simples. A tomada de decisão do programa é baseada unicamente nas percepções do agente, que para isso exige ambientes observáveis. A decisão é formulada com base em regras condicionais que mapeiam as condições atuais do ambiente em uma ação.

Os Agentes Reativos baseados em Modelos são semelhantes aos reativos simples, exceto por algumas sofisticações. Esses agentes lidam de modo mais efetivo com ambientes parcialmente observáveis, controlando assim apenas uma parte do meio externo. A outra parte, que são as informações que estão indisponíveis, o agente trata por meio de um modelo do funcionamento do mundo, criado para representá-lo internamente. Desse modelo também devem constar algumas informações referentes à forma como o mundo evolui independente da atuação do agente e do modo como as suas ações deliberadas alteram esse meio, permitindo assim, que ele tenha conhecimento das implicações de seu comportamento no ambiente sem depender exclusivamente de seus sensores.

Para algumas situações o conhecimento momentâneo do meio pode ser insuficiente para que o agente decida por algo, tornando-se necessário algo que direcione as suas ações. Os Agentes baseados em Objetivos são evoluções da arquitetura anterior, conseguidas pelo acréscimo de uma pauta contendo informações que descrevam o objetivo do agente e atribuam ao seu comportamento um caráter de satisfação no exercício de suas ações. 
O caráter de satisfação é implementado através do alcance dos objetivos estipulados, que influem diretamente na tomada de decisão. Também é comum a presença de mecanismos que propiciem ao agente a habilidade de planejamento para que a sequiência de suas ações altere o ambiente em consonância com o seu objetivo.

Quando um agente baseado em objetivo está em operação não há uma preocupação com os benefícios ou malefícios daquele determinado planejamento construído para alcançar o objetivo inicial. Em alguns momentos cabe realizar um novo planejamento ou corrigi-lo durante o percurso, conforme a utilidade das possíveis decisões; assim operam os Agentes baseados na Utilidade.

Um outro mecanismo acoplado ao comportamento de agentes é o responsável pelo aprendizado. A habilidade de aprendizado atribuída ao agente permite que ele próprio otimize o seu funcionamento ao longo do tempo, dispensando assim um conhecimento inicial mais amplo.

Para que o agente melhore a sua atuação é necessária a presença de uma entidade Crítica. Ela avalia as percepções para promover alterações no programa, e para que essas alterações sejam feitas a entidade crítica se baseia num padrão fixo de desempenho, além de desenvolver um caráter explorador.

O caráter explorador propõe ao agente que novas experiências sejam realizadas, mesmo que as ações sejam classificadas como ruins no curto prazo, mas que no longo prazo lhe agregue novos conhecimentos e experiência de vida.

Uma forma prática de implementar a habilidade de aprendizado, que foi inicialmente relatada por Turing, seria primar por uma espécie de desempenho ou satisfação pessoal, penalizando ou recompensando o agente conforme este for se desenvolvendo no meio.

\subsection{Raciocínio Probabilístico}

Em muitos casos o aprendizado soluciona, ou ao menos ajuda, a contornar problemas relacionados à falta de conhecimento inicial. No entanto, na maioria dos casos o agente deve lidar com ambientes parcialmente observáveis. Essa falta de 
informações sobre o ambiente gera incertezas e obriga os agentes a serem capazes de deliberar mesmo frente a tais limitações.

Com o intuito de resumir essa incerteza, o raciocínio probabilístico procura desenvolver uma lógica baseada nas percepções ou evidências, e em informações advindas de sua experiência ou conhecimento inicial. $\mathrm{O}$ resultado prático dessa lógica fornece um Grau de Crença que pode estar associado a uma sentença ou uma informação.

O grau de crença tem a finalidade de descrever o quanto se espera que a informação ou sentença associada seja verdadeira. Para se computar esse grau o agente se baseia em probabilidades a priori, ou incondicionais, e $\boldsymbol{a}$ posteriori ou condicionais. As a priori são informações fixas, que não se alteram com a constatação das evidências, já as a posteriori estão vinculadas à análise racional das evidências e se relacionam diretamente com o grau de crença de uma determinada informação.

A especulação formada com base no grau de crença e no raciocínio empregado para obtê-lo com base nas evidências pode ser denominado de processo de Inferência Probabilística. Na literatura existem diversas metodologias para se produzir inferências como a Teoria de Bayes e a Lógica Nebulosa.

\subsubsection{Teoria de Bayes}

A equação que rege a teoria "bayesiana", também conhecida como Lei ou Teorema de Bayes, é uma decorrência da Regra do Produto ${ }^{8}$. Essa teoria é muito difundida em Raciocínio Probabilístico por tratar a incerteza com base em conhecimento a priori sendo este, por sua vez, corrigido e amparado por uma informação condicional, que é decorrente da observação de fenômenos - no caso, evidências.

Após manipular a regra do produto como descrito na Figura 8 , a equação passa a ser a base da teoria de Bayes. Essa equação é composta por um redutor de certeza da probabilidade a priori ou "likelihood" como é mais conhecido e claro, a probabilidade a priori da hipótese, ambos como dividendos e a probabilidade a priori

\footnotetext{
${ }^{8}$ A Regra do Produto é baseada nas probabilidades condicionais ou posteriores, mas pode ser definida em termos de probabilidades incondicionais (Russell, 2004).
} 
da evidência como um normalizador ou quociente. Assim, a crença da existência da hipótese $H$, dado que existe a evidência $e$, depende da verossimilhança $P(e / H)^{9}$ e da probabilidade a priori de $H$ (Feller, 1968).

$$
\begin{aligned}
& P(a \mid b)=\frac{P\left(a^{\wedge} b\right)}{P(b)}\left[\begin{array}{l}
P\left(a^{\wedge} b\right)=P(a \mid b) * P(b) \\
P\left(a^{\wedge} b\right)=P(b \mid a) * P(a)
\end{array}\right. \\
& \mathrm{P}(\mathrm{a} \mid \mathrm{b}) * \mathrm{P}(\mathrm{b})=\mathrm{P}(\mathrm{b} \mid \mathrm{a}) \text { * } \mathrm{P}(\mathrm{a}) \\
& P(a \mid b)=\frac{P(b \mid a) * P(a)}{P(b)} \\
& \mathrm{P}(\mathrm{H} / \mathrm{e})=\frac{\mathrm{P}(\mathrm{e} / \mathrm{H}) \star \mathrm{P}(\mathrm{H})}{\mathrm{P}(\mathrm{e})}
\end{aligned}
$$

Figura 8: Teorema de Bayes.

Essas evidências observadas e por consequiência o possível conjunto de hipóteses analisadas podem ser conjugadas, de modo a expressar melhor o ambiente a ser percebido pelo agente. Tais multiplicidades, tanto de evidências quanto de hipóteses, permitem levar em consideração com grande amplitude a inter relação entre todas essas informações a priori e a posteriori, criando assim, um grande relacionamento entre as crenças.

Uma situação possível para ilustrar a conjugação entre hipóteses e evidências bem como a geração de níveis de certeza de crenças seria o exemplo numéricofictício a seguir:

Um agente dotado de raciocínio probabilístico bayesiano é capaz de inferir e estimar níveis de certeza relacionados às hipóteses:

\footnotetext{
${ }^{9}$ A verossimilhança ("likelihood") $\mathrm{P}(\mathrm{e} / \mathrm{H})$ descreve a crença da ocorrência de e, na certeza de $\mathrm{H}$.
} 
- possibilidade de chuva;

- alguém vir a irrigar as proximidades do ambiente;

- vir a lavá-lo.

Para que o agente realize o raciocínio, ele é informado através de observações como:

- chão molhado;

- céu nublado;

- horta ou jardim nas proximidades;

- presença de mangueira de jardinagem ou balde de limpeza.

\begin{tabular}{|c|c|c|}
\hline Código & Descrição das Evidências $\boldsymbol{e}$ & P (e) \\
\hline e1 & Chão molhado & 0.25 \\
\hline e2 & Céu nublado & 0.22 \\
\hline e3 & Horta ou jardim próximo & 0.11 \\
\hline e4 & Presença de mangueira ou balde de limpeza & 0.12 \\
\hline
\end{tabular}

Tabela 1: Quadro de evidências conhecidas pelo agente.

\begin{tabular}{|c|c|c|}
\hline Código & Descrição das Hipóteses H & $\mathbf{P}(\mathbf{H})$ \\
\hline H1 & Chuva & 0.12 \\
\hline H2 & Irrigação & 0.17 \\
\hline H3 & Lavagem & 0.21 \\
\hline
\end{tabular}

Tabela 2: Quadro de hipóteses (crenças) conhecidas pelo agente.

\begin{tabular}{|c|c|c|c|}
\cline { 2 - 4 } \multicolumn{1}{c|}{} & H1 & H2 & H3 \\
\hline e1 & 0.85 & 0.79 & 0.81 \\
\hline e3 & 0.96 & 0.15 & 0.03 \\
\hline e4 & 0.14 & 0.93 & 0.11 \\
\hline
\end{tabular}

Tabela 3: Quadro de probabilidades das evidências na certeza da hipótese $P(e / h)$.

Tais observações compõem então o quadro de evidências que virão a auxiliar o agente a estimar a certeza da veracidade das hipóteses, de modo que a portadora do maior nível em comparação com as demais será a mais provável.

Essa estimativa do nível de certeza da crença é melhor trabalhada nas situações em que a maturidade e a experiência sejam promovidos; em outras palavras, pode-se afirmar que conforme o agente observe e estime inúmeras vezes, o seu trato com os níveis será cada vez mais íntimo e confiável. 
Após o conhecimento das informações internas do agente A, sabe-se que este é notificado de "Céu nublado" (e2). Sendo assim, o agente desenvolve o seguinte raciocínio (Tabela 1, Tabela 2, Tabela 3):

$$
\begin{aligned}
& \mathbf{P}(\mathbf{h} 1 / \mathbf{e} 2)=[\mathrm{P}(\mathrm{e} 2 / \mathrm{h} 1) * \mathrm{P}(\mathrm{h} 1)] / \mathrm{P}(\mathrm{e} 2)=>0.96 * 0.12 / 0.22=>\mathbf{0 . 5 2} \\
& \mathbf{P}(\mathbf{h} 2 / \mathbf{e} 2)=[\mathrm{P}(\mathrm{e} 2 / \mathrm{h} 2) * \mathrm{P}(\mathrm{h} 2)] / \mathrm{P}(\mathrm{e} 2)=>0.15 * 0.17 / 0.22 \Rightarrow \mathbf{0 . 1 2} \\
& \mathbf{P}(\mathbf{h} 3 / \mathbf{e} 2)=[\mathrm{P}(\mathrm{e} 2 / \mathrm{h} 3) * \mathrm{P}(\mathrm{h} 3)] / \mathrm{P}(\mathrm{e} 2)=>0.03 * 0.21 / 0.22 \Rightarrow \mathbf{0 . 0 3}
\end{aligned}
$$

Logo, com base nos cálculos deduzidos anteriormente, o agente passa a acreditar com mais de $50 \%$ de certeza de que poderá chover num breve espaço de tempo.

\subsubsection{Lógica Nebulosa}

A Lógica Nebulosa ("Fuzzy Logic") surgiu na década de 60 a partir de um contexto matemático que incidiria sobre o aspecto de pertinência dos elementos de um dado conjunto. Tal contexto matemático apresentou a definição de conjunto nebuloso como "uma classe de objetos com níveis contínuos de pertinência" e que esses conjuntos "são caracterizados por uma função que associa para cada objeto a um nível de pertinência limitado entre 0 e 1" (Zadeh, 1965).

Com aplicação nas mais diversas áreas, sobretudo os campos de classificação de padrões e processamento de informações, a Lógica Nebulosa se diferencia dos métodos convencionais de Raciocínio Probabilístico pela forma com que lida com a imprecisão. A resolução desse aspecto vago é fomentada por uma estrutura que provê mecanismos matemáticos para modelar e processar a linguagem natural: Computação com Palavras ${ }^{10}$ (Zadeh, 1996).

\begin{tabular}{|l|l|l|l|l|l|l|l|l|l|l|l|}
\hline SE & $X$ & É & PEQUENO & E & $Y$ & É & MÉDIO & ENTÃO & $Z$ & É & DISTANTE \\
\hline SE & $X$ & É & MÉDIO & E & $Y$ & É & MÉDIO & ENTÃO & $Z$ & É & PRÓXIMO \\
\hline SE & $X$ & $\hat{E}$ & GRANDE & E & $Y$ & $\hat{E}$ & BAIXO & ENTÃO & $Z$ & É & MÉDIO \\
\hline
\end{tabular}

Tabela 4: Quadro de regras que utiliza a sintaxe Modus Ponens para computar palavras.

\footnotetext{
${ }^{10}$ Computação com Palavras: Zadeh a descreve como a manipulação de números e símbolos de modo racional através de conclusões expressas por palavras determinadas pelo processo mental de modelagem.
} 
Esse mecanismo de racionalizar sobre uma modelagem humana de alto nível e, portanto, puramente lingüística, resulta em inúmeros redutos de imprecisão. A Lógica Nebulosa visa atuar justamente nesse escopo, sendo altamente recomendável para sistemas de tomada de decisão, automação e controle lógico (Zadeh, 1973). Entretanto, como já descrito, a computação com palavras opera sobre expressões lógicas (conclusivas) (Tabela 4) e com incidência em variáveis lingüísticas; todas modeladas através da experiência e do conhecimento extraídos de um especialista.

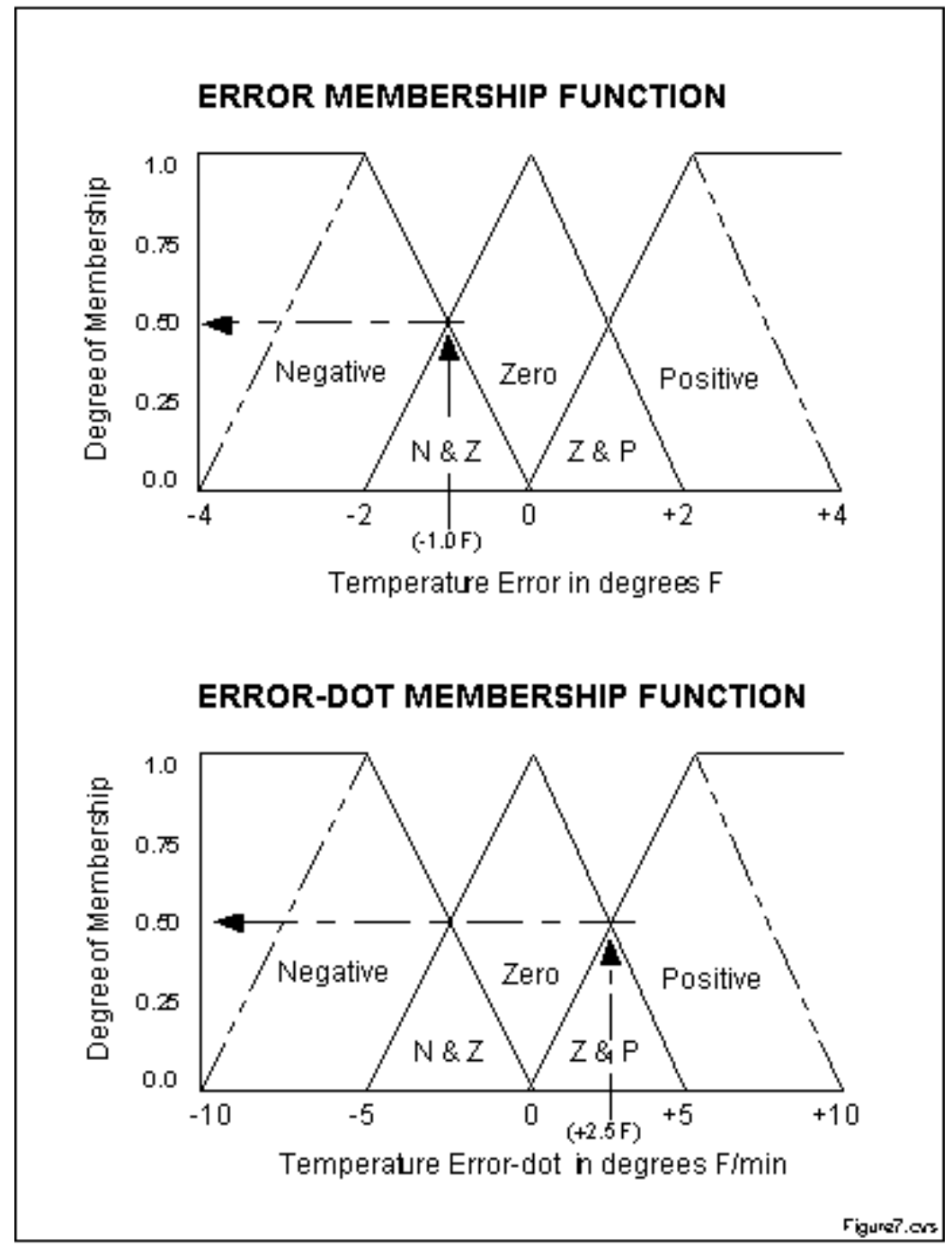

Figura 9: Gráfico dos níveis de pertinência dos conjuntos nebulosos (Kaehler, 2005).

O processo de inferência nebulosa é obtido através do enquadramento de dados de entrada, caracterizados por serem “crisps”, nos conjuntos nebulosos. Após o mapeamento do dado é obtida a granularidade (pertinência) daquele ponto ("fuzzy singleton”) (Figura 9) e partir disso é mapeado em uma base de regras nebulosas. 
Essa base de regras obedece à sintaxe Modus Ponens e partir dela são desenvolvidos os gráficos da inferência nebulosa ${ }^{11}$ (Lee, 1990a) (Lee, 1990b).

\subsection{Conclusões}

Este capítulo contribuiu para a consolidação do conhecimento empregado no desenvolvimento do modelo de comportamento pretendido. Em Vida Artificial, o contexto social e epistemológico, bem como a adaptação, incidem diretamente na abordagem da pesquisa; servindo de base para a concepção do modelo, das regras e das variáveis a serem observadas.

A Ciência Cognitiva fortalece o caráter epistemológico da pesquisa, enquanto a Inteligência Artificial oferece ferramentas para tratar as questões que se apresentam. Sendo agentes inteligentes um dos conceitos principais, as atenções para o desenvolvimento deste arcabouço (framework) se voltaram para a definição de uma estrutura interna de agente, bem como para os aspectos externos relativos ao ambiente.

A partir da relação desses assuntos foi possível propor um modelo de comportamento. Já os detalhes de como as informações são processadas internamente teve a sua formação através do tópico de Raciocínio Probabilístico.

Comparativamente a lógica de Bayes pode ser apontada como um mecanismo de inferência tomando como base evidências incondicionais e um certo conhecimento a priori, enquanto que a Lógica Nebulosa trabalha melhor com aspectos da imprecisão que envolvam a pertinência em conjuntos de classificação ou identificação. Desse modo, o mecanismo para a manipulação das informações incertas ou expectativas geradas pelos agentes será processado com base na Teoria de Bayes.

\footnotetext{
${ }^{11} \mathrm{O}$ processo de inferência pode ser obtido através de alguns mecanismos para mapear graficamente um "fuzzy singleton", dentre eles, os mais utilizados são: regra do Mínimo de Mandani e a regra do produto de Larsen.
} 


\title{
3 VisUALIZAÇÃo DE SIMULAÇÕES
}

\begin{abstract}
"Estou cercado por - nada. Não por espaço vazio, pois não há espaço para ser vazio. Não por trevas, pois não há nada que possa ser destituído de cor. Simplesmente uma ausência, aguardando o momento de se tornar uma presença. Imagino ordens: que seja feito o espaço. Mas que tipo de espaço? Tenho escolhas: espaço tridimensional, espaço multidimensional, ..."
\end{abstract}




\subsection{Realidade Virtual como Interface}

\subsubsection{Evolução das Interfaces}

A expansão do conceito de Interface foi datada pela aula de Ivan Sutherland: "A Última Fronteira da Interface". Sutherland, que foi um dos mentores da Computação Gráfica Interativa, em 1965 esboçou os primeiros conceitos da futura Realidade Virtual (RV). As idéias concebidas por Sutherland, em suma, refletiam em uma janela (que não poderia ser imaginada como uma tela de computador), através da qual um mundo, supostamente real, poderia ser visualizado (Cardoso, 2003).

A introdução destes conceitos para visualizar e interagir com as informações fez com que as interfaces, mais tarde, evoluíssem. Nesse caminho evolutivo, destacam-se como principais marcos: as telas monocromáticas ou terminais que interpretavam linhas e mais linhas de comandos constituídos de parâmetros (prompts, shells, etc), os ambientes gráficos bidimensionais baseados em ícones e por fim, os atuais dispositivos de imersão que reproduzem ambientes sofisticados ao mesmo tempo em que os sentidos dos usuários são estimulados de modo a dar ao usuário a sensação visual de estar no ambiente virtual a ele apresentado.

A oferta desses novos recursos disponibilizados pela RV ao desempenhar o papel de interface nas mais diversas aplicações, possibilitou a exploração de novas informações. Existiam situações que até então eram demasiadamente complexas para serem interpretadas por meio de uma interface computacional, e a introdução desta nova tecnologia, propiciando novas formas de visualização tridimensional e melhor exploração dos sentidos, minimizou os problemas inerentes a estes casos.

Devido ao fato dessa interface poder ser usada nas mais diversas aplicações configura-se como interdisciplinar, e por estar atravessando um processo evolutivo e de amadurecimento, ainda não existe uma definição clara do conceito de RV.

Uma das definições mais aceitas seria: "a forma mais avançada e aprimorada de interface de usuário, além de possuir aplicação nas mais diversas áreas do conhecimento, disponibiliza elaboradas técnicas de visualização, manipulação e interação de dados ou informações" (Trindade, 1999). 
Uma outra forma muito utilizada para abordar a RV parte da elaboração de um espaço tridimensional cujas dimensões representam: interação, envolvimento e imersão. Essas três idéias podem ser encontradas individualmente em outras frentes da computação, mas na RV a sua coexistência é o fator determinante de sua definição (Kirner,1997).

\subsubsection{Manipulação dos Sentidos}

A idéia de visualização do mundo real por meios computacionais foi sendo aprimorada, e a necessidade de manipulação dos sentidos ganhou relevância para que esse mundo representado parecesse real. Desse momento em diante uma frase passou a acompanhar o conceito de RV: "Feeling of Being There".

Direcionando os esforços tecnológicos e intelectuais para o sucesso da sensação de "sentir-se como estando lá", a RV desenvolveu as premissas de interação, envolvimento e imersão (Morie, 1994).

No caso da interação é possível entre um único usuário (Interação Individual) ou entre vários usuários (Interação em Grupo) podendo desenvolver comunicação, colaboração e cooperação através de um ambiente compartilhado.

Em RV, aspectos ligados diretamente às funcionalidades que o sistema oferece ao usuário são abordadas pelo Envolvimento como Ativo ou Passivo. Um envolvimento ativo pode ser ilustrado por situações em que o usuário interaja e manipule o ambiente, de modo a afetar seu estado atual ou que sua repercussão interfira no estado de outros usuários. Já situações ausentes de perturbações ou grandes interferências no ambiente são caracterizadas como envolvimento passivo.

Mesmo não sendo a mais importante das três premissas, o conceito de Imersão é o que influencia diretamente no sentimento de estar situado no ambiente tão almejado pela RV. Contudo, é comum o desenvolvimento de aplicações que mesmo sendo Não-Imersivas são aceitas dentro do contexto de RV.

Todos os sentidos passaram a integrar a lista de potenciais mecanismos para propiciar a ilusão de presença dentro do ambiente virtual. Periféricos e dispositivos 
denominados de não-convencionais encarregam-se de realizar a entrada e a saída do sistema criado para implementar tal interface (Figura 10).

O desafio dos profissionais envolvidos nesta área tem sido desde então usar técnicas computacionais de simulação de som, movimento e outros a fim de que, apesar do mundo ser virtual, seu usuário possa senti-lo e usá-lo como se fosse real; desenvolvendo assim, a idéia do sentimento de presença que é tão pertinente à interface.

Como um dos principais dispositivos não-convencionais de RV, o sistema de múltiplas projeções em paredes, piso e teto de uma sala propicia aos seus usuários um pleno sentimento de imersão. Isso é alcançado graças às projeções estereoscópicas e ao fato do usuário se localizar dentro do sistema físico, que pode ainda comportar outros usuários simultaneamente (Zuffo, 2001).

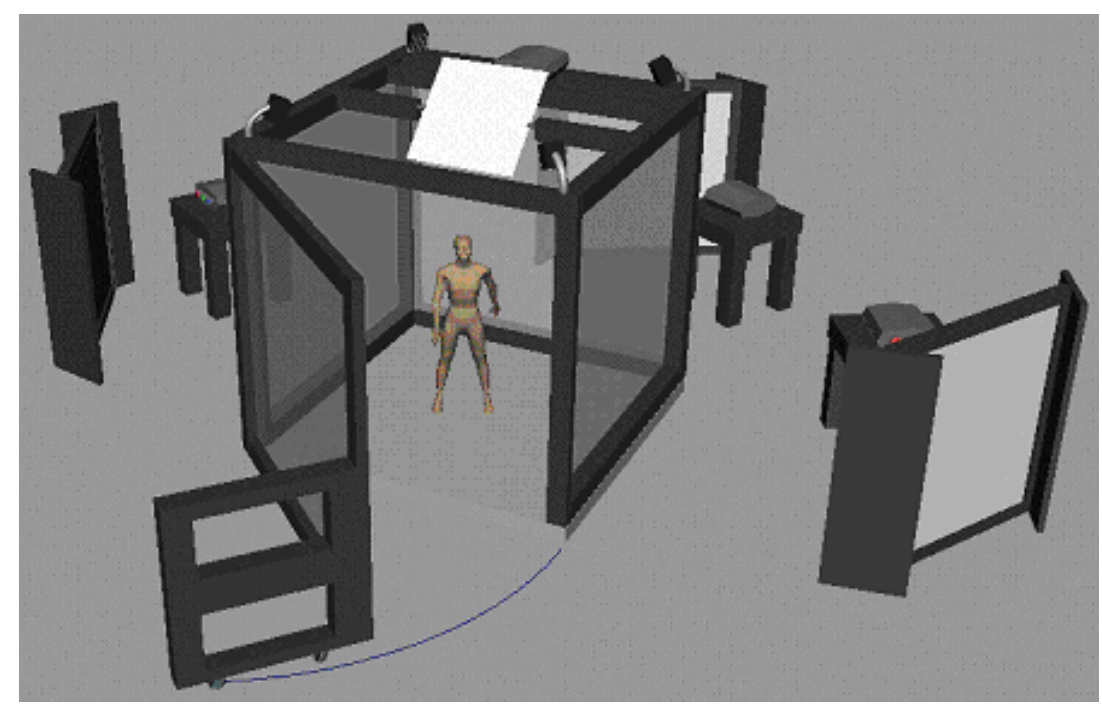

Figura 10: Disposição da Caverna Digital da USP.

A combinação do estímulo desses sentidos reunidos para manipulação, visualização e interação com os mais diversos tipos de dados e informações conceitua a RV sob suas características gerais. Tais características são particularmente interessantes em simulações ou experimentos cuja real presença do usuário no local seja inviável financeiramente (custo da expedição), ou fisicamente (observação de fenômenos quânticos ou astrofísicos), ou que represente algum tipo de risco (ações de resgate). Porém aplicações de outras naturezas, como estudos de comportamentos de grupos sociais podem também se valer desta tecnologia. Este é o 
caso da aplicação proposta nesta dissertação, na qual o uso da RV pode melhorar a compreensão de como se dão os relacionamentos entre as pessoas de um pequeno grupo social.

\subsubsection{Aplicações e Sistemas de RV}

Em meados da década de 90, sobretudo, a partir da segunda metade com a expansão da indústria dos jogos domésticos e em redes, a RV ingressou no processo de popularização como consequiência da redução dos custos de seus dispositivos e como meio alternativo para o entretenimento.

Além dos sistemas de RV, surgiram outros decorrentes como os sistemas de Realidade Aumentada $\left(\mathrm{RA}^{12}\right)$, Realidade Múltipla $\left(\mathrm{RM}^{13}\right)$ e Telepresença. Todos esses sistemas se caracterizam por incorporarem múltiplas tecnologias e possuírem aplicações multidisciplinares. Os mais diversos e complexos segmentos da Medicina e da Engenharia, entre outros, têm aderido ao uso dos recursos propiciados por estas novas interfaces.

No âmbito médico a RV revoluciona, pois permite a visualização de dados muito mais complexos e ainda agrega a interatividade para auxiliar na interpretação das informações tratadas. Pesquisas que recriam situações complexas de serem assistidas no meio real, como tratamento de fobias, são exemplos de casos de sucesso (Jacob, 2001).

Ainda no escopo de aplicações médicas, tais interfaces têm contribuído para a realização de simulações e principalmente em treinamentos. Existem situações onde há a necessidade de combinar informações visuais com a precisão de alguns sentidos, como é o caso da importância da quantidade de força muscular aplicada pelo médico durante a coleta de líquido da medula óssea de pacientes.

Indo de encontro à idéia básica de manipulação dos sentidos, sistemas de RV com mecanismos táteis de retorno de força, e ao mesmo tempo com visualização

\footnotetext{
12 A RA interpola dados reais e virtuais, através da combinação da visão do ambiente real com a síntese do ambiente virtual, utilizando-se a sobreposição da imagem real com a informação gerada pelo ambiente virtual.

${ }^{13}$ A RM é muito semelhante a RA, mas se caracteriza pela inserção de novas informações em imagens reais, amplificando assim, o conhecimento desejado.
} 
detalhada do processo invasivo de agulhas médicas, têm se tornado uma ferramenta auxiliar durante o treinamento desses médicos (Machado, 2001). Esse tipo de aplicação ganha ainda mais força pelo fato do risco de lesionar a coluna lombar de um paciente ser muito alto.

$\mathrm{Na}$ área de engenharia os trabalhos desenvolvidos utilizando a simulação e a reprodução de fenômenos reais possibilita a diminuição dos custos na criação de protótipos, permite avaliar a influência da iluminação em ambientes fechados, ou da atuação de forças físicas em corpos aerodinâmicos (aviões, automóveis, etc), além de possibilitar sofisticadas visualizações numéricas (Menezes, 2001).

Um outro segmento ao qual a RV tem servido é o cultural, onde ambientes inteiros são reproduzidos fielmente, tornando seu acesso possível a pessoas, que mesmo sem acesso físico, podem assim conhecer e explorá-los virtualmente (Meiguins, 2001) (Tavares, 2001). Desenvolvendo melhor esse segmento, pesquisas direcionadas a cooperação e colaboração não apenas para situações culturais, mas para todas as outras atividades, tem conciliado a presença de humanos reais com personagens virtuais cujo comportamento é controlado por computador (Aquino, 2001) (Brega, 2001) (Kwamoto, 2001) (Rosa, 2001)

Atualmente a inserção da TV Digital na sociedade tem fortalecido a recente área de mídias eletrônicas interativas, a qual engloba algumas aplicações de RV. Dentro deste novo segmento, com principal atenção para o entretenimento, pesquisas destinadas ao escopo de personagens virtuais controlados por computador e passíveis de interação tem contribuído significativamente para o desenvolvimento desse tipo de tecnologia autônoma e interativa.

\subsection{Humanos Virtuais Autônomos}

\subsubsection{Aplicações em Meios Digitais}

Atualmente não é muito difícil se lembrar de um personagem virtual, um daqueles "bichinhos" engraçados, bem caricatos e que ao mesmo tempo são capazes de despertar espanto e admiração pela semelhança com o real, seja pela movimentação, 
pela sua textura ou pela iluminação aplicada. A questão é que eles estão por toda parte, seja nas telas de cinema, nos jogos eletrônicos, nas propagandas e até mesmo em áreas que primam por uma seriedade como é o caso dos noticiários (Figura 11), (Monsters, 2006), (Lord, 2006), (Matrix, 2006).

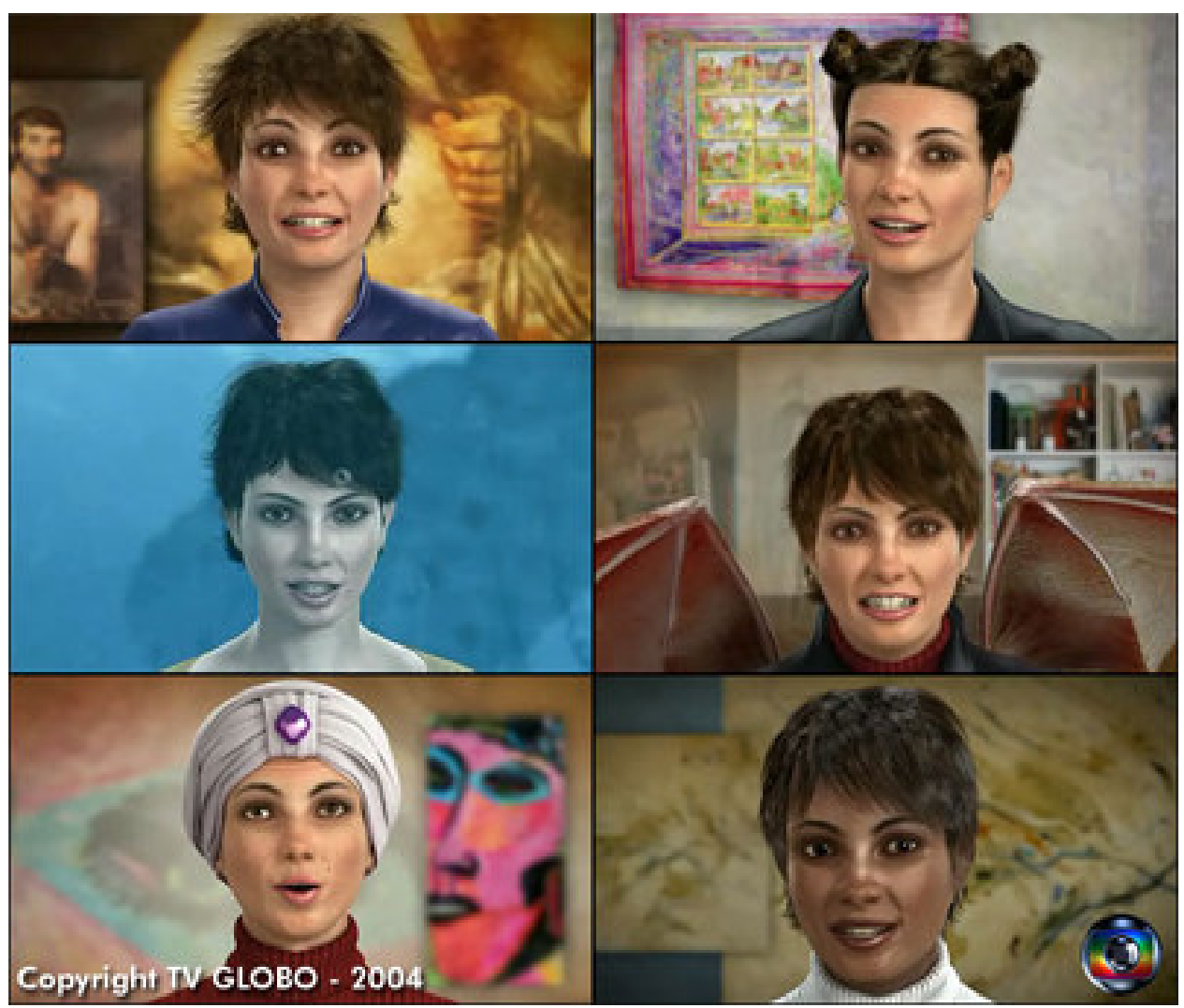

Figura 11: Eva Byte: Apresentadora Virtual (Amaral, 2004).

No caso específico dos humanos virtuais, existem diversas aplicações como trabalhos voltados para tratar simulações, entretenimento, ambientes virtuais compartilhados, comércio eletrônico e como método alternativo ou complementar a sistemas como o de Telepresença.

As simulações utilizando humanos virtuais normalmente tratam de questões como as de emergência, as ergonômicas, etc. Trabalhos englobados pelas situações de emergência podem ser ilustrados como evacuação de ambientes fechados, perigo de incêndio, tratamento de fobias, dentre outros. Já os ergonômicos normalmente possuem um comprometimento com os limites físicos mais elevados que o normal, onde tratam de articulações, liberdade de movimentos, disposição e facilidade de 
acesso a determinados recursos, como por exemplo, os automobilísticos (Musse, 2001b).

$\mathrm{Na}$ linha do entretenimento é comum encontrar protagonistas virtuais, ou mesmo um filme inteiro com efeitos de Computação Gráfica e animação de personagens virtuais, como é o caso do filme Final Fantasy. Este filme revoluciona a arte cinematográfica por apresentar todos os humanos de forma bastante convincente, demonstrando inclusive suaves nuances de sentimento, caráter e busca pela sobrevivência, que são aspectos muito íntimos do estereótipo humano.

Ainda no escopo do entretenimento, outro exemplo é a personagem que foi desenvolvida por Alceu Batistão (Figura 12). Esta personagem, denominada KAYA, tem sito muito divulgada em razão de sua qualidade.

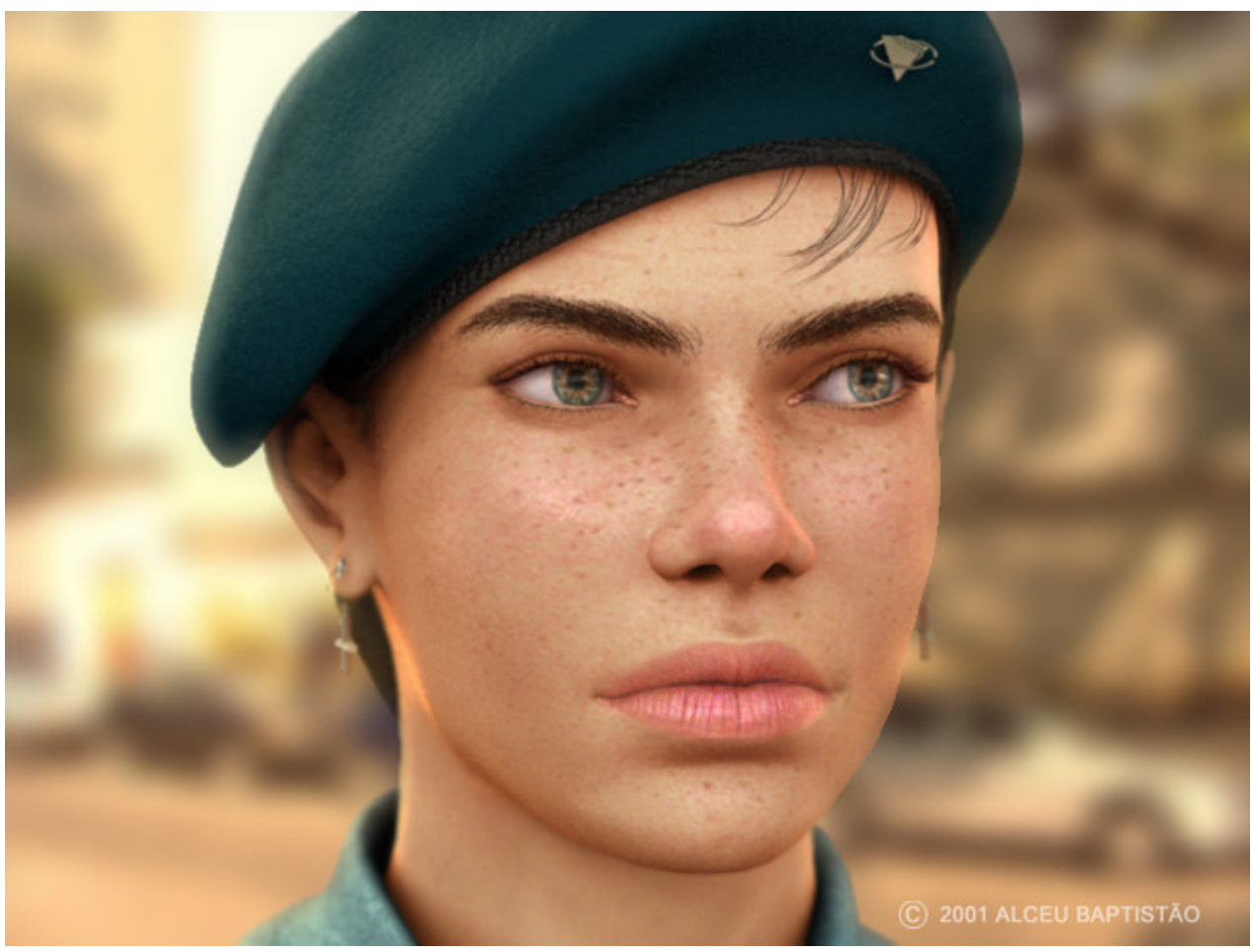

Figura 12: Personagem Kaya (Batistão, 2006).

Em razão do sucesso e do caráter tecnológico, esse tipo de aplicação se inseriu em noticiários; surgindo então, os apresentadores virtuais. A primeira apresentadora foi Ana Nova cujo nome foi inclusive atribuído ao telejornal da Internet no qual a apresentadora aparece. A partir de seu lançamento em 1999 surgiram significativas transações para a aquisição dos direitos autorais de Ana Nova 
e outras tantas que foram criadas. No Brasil, em 2004 surgiu a Eva Byte (Figura 11) que acabou desempenhando a função de costela de Adão para o comentarista virtual Eureka (Figura 13) (Aninformática, 2004).

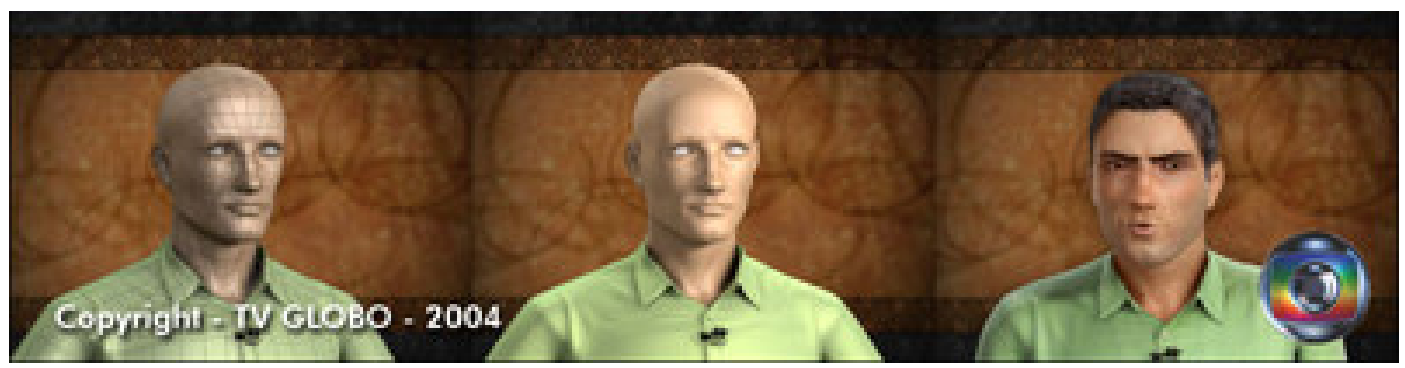

Figura 13: Eureka: Comentarista Virtual de Esportes (Vilela, 2006).

Os "chatterbot" são outro exemplo de humanos virtuais, só que neste caso existem algumas peculiaridades. Eles possuem uma aparência física menos trabalhada e possuem um sistema de interpretação de linguagem natural, além de possuírem um forte armazenamento de dados por trás da aplicação. Como exemplo podemos citar o chatterbot Cybelle no cenário nacional (Cybelle, 2006). Esse tipo de aplicação tem uma participação muito grande no cenário educativo para a confecção de professores virtuais aplicados a Educação a Distância (Leonhardt, 2006).

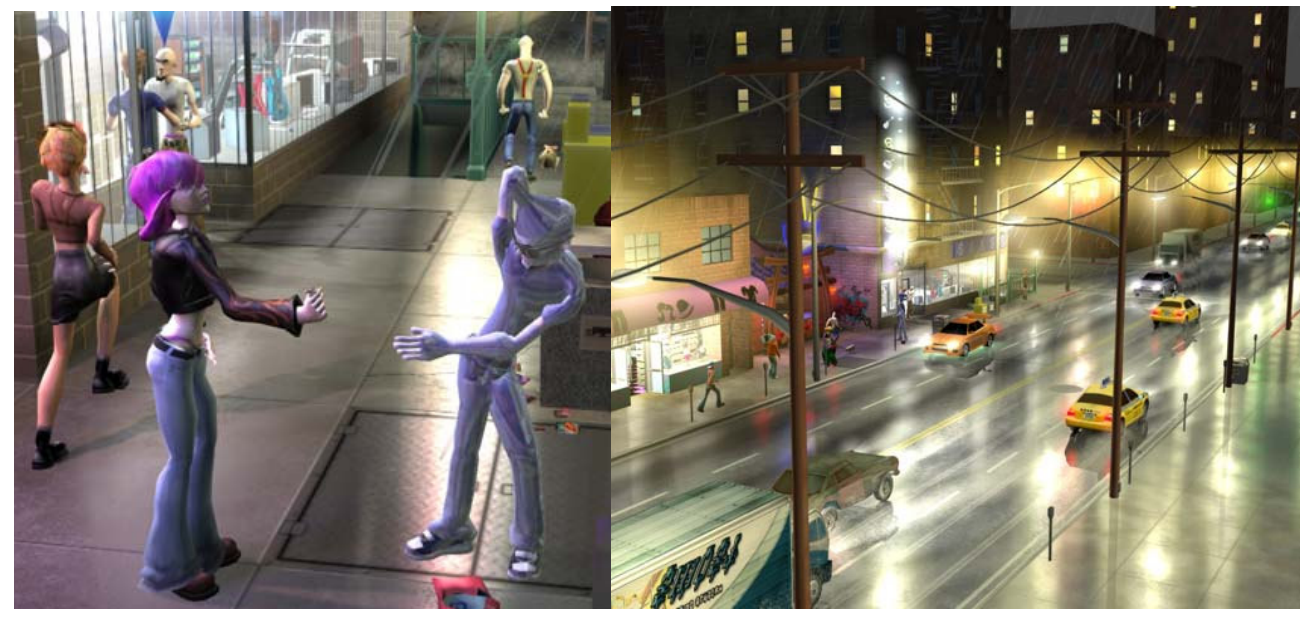

Figura 14: Jogo de Simulação da Vida Social Humana (TheSims, 2006).

Para finalizar a presença dos humanos virtuais aplicados ao entretenimento, cabe destacar sua participação nos jogos eletrônicos, onde exercem papéis tão distintos quanto simplesmente representar um usuário, ou interpretar um terrorista que deve ser procurado. Esse tipo de jogo de simulação de vida humana ganha 
destaque pela preocupação com o comportamento desses humanos virtuais. O comportamento pode decorrer da procura pela satisfação pessoal, da busca pelo conhecimento, da realização das necessidades fisiológicas, dentre outros parâmetros que condicionam a vida desses personagens (Figura 14) (TheSims, 2006).

Já no escopo de Ambientes Virtuais Compartilhados os humanos virtuais podem desempenhar o papel de entidade representativa do usuário ou ainda serem controlados pelo próprio sistema e servirem de figurantes no ambiente. Um exemplo de ambiente virtual compartilhado cujas representações humanas são realizadas por esse tipo de personagem é o Active Worlds, que pode ser definido como um ambiente 3D para troca de experiências por meio da Internet (Figura 15) (Active, 2006).

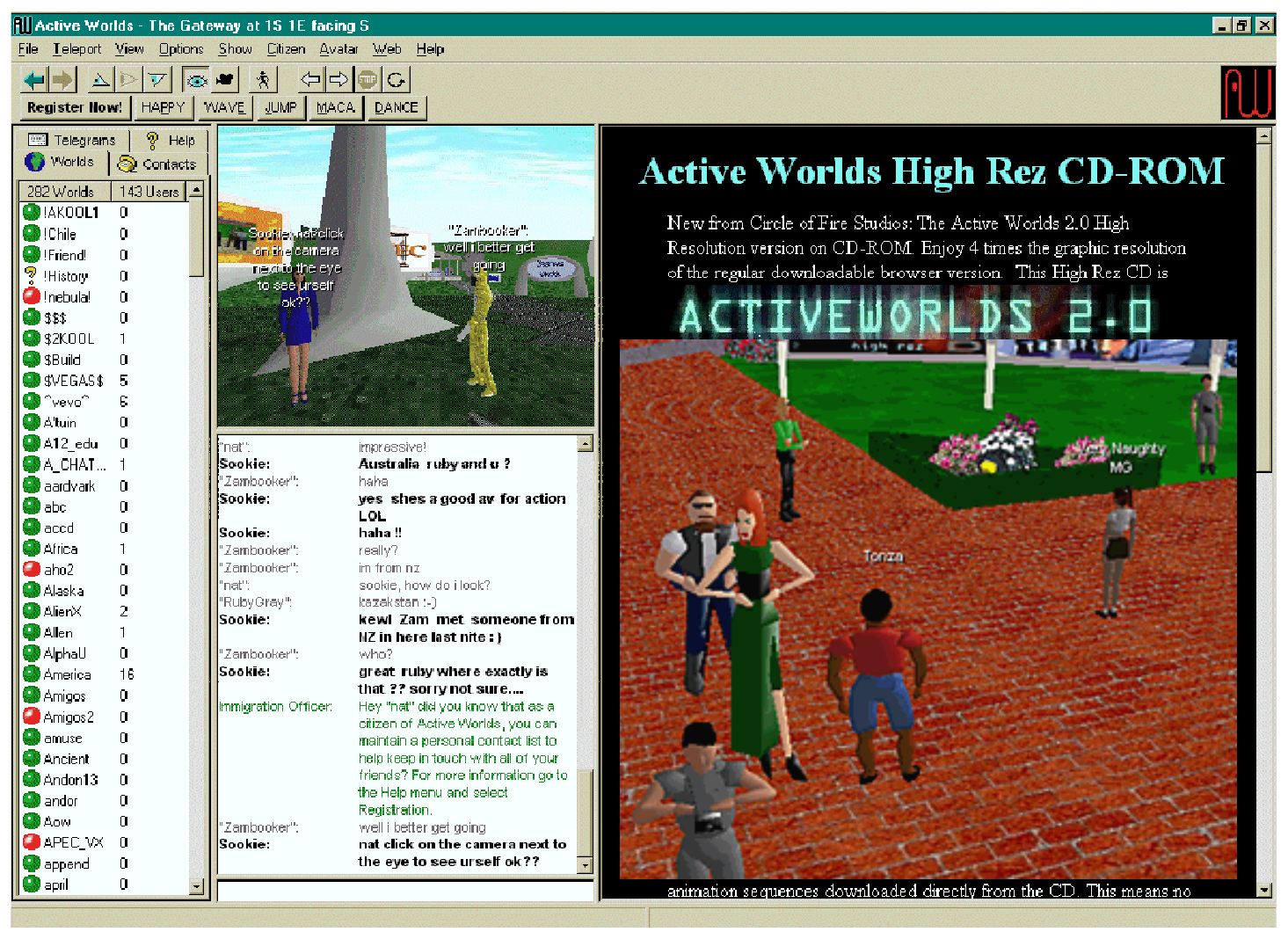

Figura 15: Tela Principal do Navegador do Active Worlds (Active, 2006).

\subsubsection{Aspectos Envolvidos na Representação e Controle}

Os humanos virtuais atendem a uma vasta gama de aplicações e como conseqüência englobam uma série de aspectos relacionados ao caráter visual (Computação Gráfica, Realidade Virtual, processamento de imagens, técnicas de animação e ergonomia), além dos associados com a presença de uma entidade gerenciadora (Inteligência 
Artificial, Vida Artificial, agentes autônomos e sistemas de comunicação). Assim, torna-se evidente o grande esforço atribuído ao desenvolvimento de humanos virtuais. Mas é interessante notar que se pode estabelecer uma divisão desse trabalho em duas frentes: uma para o caráter visual e outra para o de seu gerenciamento.

O caráter visual corresponde ao processo de modelagem de uma forma geométrica tridimensional e a programação de seus movimentos (animação). Esse molde, que também recebe o nome de entidade gráfica, em se tratando de um humano virtual, deve sempre apresentar um visual semelhante ao de um ser humano real. Justamente por existir esse comprometimento com a fidelidade, esses moldes se tornam pesados computacionalmente, o que demanda recursos de otimização, como ocorre no caso dos níveis de detalhamento ${ }^{14}$.

O processo de animação dessa entidade gráfica pode ser realizado de acordo com a tecnologia empregada ${ }^{15}$. Contudo essa tecnologia para animação normalmente está comprometida com a necessidade da sua realização ser efetuada em tempo real, o que limita muito o processo. Por fim, outro fator de influência na animação é o número de articulações presentes na entidade gráfica - quando esta for articulada.

Em acréscimo ao molde gráfico e ao seu conjunto de animações, algumas aplicações fazem uso de uma entidade gerenciadora, que se integra à parte visual. Essa integração promove a autonomia, que é considerada o principal parâmetro evolutivo para os diversos tipos de humanos virtuais (Donikian, 1999).

Na literatura a autonomia é destacada para classificar os humanos virtuais entre os três principais tipos existentes: o Avatar (representante virtual de uma pessoa que interaja com o sistema), os Autônomos e os que apresentam Comportamento Social (Thalmann, 1999). A ordem de apresentação desses tipos de humanos virtuais representa uma linha evolutiva ao tomar por base a autonomia já levantada.

\footnotetext{
${ }^{14}$ Esse processo de otimização consiste em degradar o molde sob o aspecto do número de vértices de acordo com a sua distância do observador.

${ }^{15}$ Dentre as mais utilizadas estão a Cinemática Direta, com resultados mais modestos, e a Inversa que consiste em sofisticados cálculos (Gleicher 2001).
} 


\subsubsection{Humanos Virtuais como Avatares}

O avatar desenvolve a ação de representar o usuário em um ambiente virtual e no caso, esta representação, por ser um humano virtual, deve procurar a maior semelhança possível com o humano real. Como o avatar está intimamente comprometido com o usuário, a animação normalmente é correlata ao seu corpo físico. Assim, para aqueles humanos virtuais que possuem articulações, o sistema requer sofisticados dispositivos de captura de movimento e um software capaz de reproduzir a animação em tempo real (Thalmann, 2000).

Também existem situações menos complexas onde os dispositivos de controle são mais simples como um joystick ou mesmo um mouse e um teclado. Contudo, em ambos os casos a entidade gráfica é plenamente controlada pelo usuário (Teichrieb, 2000).

\subsubsection{Humanos Virtuais Autônomos}

Ao contrário do avatar, os humanos virtuais autônomos não são controlados pelo usuário. A sua autonomia é decorrente da independência com o meio externo. Esses humanos virtuais são controlados internamente pelo próprio sistema, podendo ser esse controle ou entidade gerenciadora denominada de mente virtual, que viria a descrever um comportamento (Balkenius, 1995) (Cavazza, 1998).

Os humanos virtuais autônomos não sofrem intervenção externa (de humanos reais) e normalmente tem as suas ações pautadas por regras, metas e objetivos, sempre consideradas no contexto espaço-temporal (ambiente) em que se encontrem. O comportamento desse tipo de personagem normalmente decorre de um processo perceptivo (mecanismos de percepção), seguido por tomadas de decisão baseadas em símbolos que representam internamente o ambiente percebido, e da existência de memória. Dessa forma, é comum encontrar na literatura a descrição de frameworks que modularizam tarefas em: Percepção, Cognição e Atuação (Donikian, 1999) (Silva, 2000). 


\subsubsection{A Percepção}

O mecanismo de percepção tem um importante papel para o humano virtual, pois é ele que promove a interface entre o comportamento do personagem e o ambiente virtual. A percepção é encarregada de gerar as sensações, que são formas de representação interna para aquilo que existe no meio externo. Essas sensações podem representar um objeto ou um evento que tenham sido detectados pela percepção, através de sensores virtuais (Musse, 1997).

Os sensores virtuais são baseados nos sentidos humanos, sendo eles: o tato, o olfato, a visão, a audição e o paladar. Contudo, em realidade virtual, principalmente por serem os sentidos mais estimulados, o tato e a visão virtual são os mecanismos mais utilizados como sensores para a percepção de humanos virtuais autônomos.

No caso do tato virtual, a detecção de colisão seria o artifício empregado. O humano virtual deveria conter regras capazes não apenas de trabalhar dados referentes à eminência de colisão com um dado objeto, mas também de vir se preparando para esse acontecimento através do planejamento de ações prévias para as potenciais colisões. Além disto pode usar esta informação não apenas como uma ação e reação entre corpos físicos, mas para assessorar a tomada de decisão.

A visão virtual, que normalmente opera em conjunto com o tato virtual, é realizada com base em técnicas de reconhecimento de padrões, onde uma câmera virtual sintetiza imagens a uma determinada freqüência. Esse procedimento recebe também o nome de visão simulada.

\subsubsection{A Cognição}

A cognição é o processo responsável por interpretar as representações do ambiente externo, que são feitas pela percepção, e por emitir um comando, sempre que julgar necessário, para uma execução de uma ação, que será realizada por seus atuadores.

A interpretação dos dados provenientes da percepção e a conseqüente análise dos mesmos, levando o personagem a interagir ou não com o ambiente, é frequientemente suportada por recursos de inteligência artificial. Dentre estes pode-se destacar os mecanismos de inferência, as bases de regras, os sistemas de tomada de decisões, o aprendizado e as máquinas de estados, dentre outros. 
O funcionamento da cognição é guiado por um ou mais objetivos, interpretando as condições daquele momento de modo que, ao interagir com o ambiente, possa manipulá-lo a fim de alterá-lo progressivamente, para que o humano virtual cumpra o seu objetivo inicial. Tais decisões podem ainda ser ponderadas por atributos de personalidade (Badler, 1997). Para isso, o seu comportamento precisa ser capaz de não apenas gerar informações que o auxiliem nesse processo, como também de mantê-las sempre atualizadas de acordo com as condições do ambiente. A essa característica de comportamento dá-se o nome de racionalidade.

Além da criação e da atualização dessas informações é necessária uma estrutura para abrigá-la e que possibilite a recuperação dessas mesmas informações em eventos passados, de modo semelhante a uma memória.

Finalizando o escopo cognitivo, cabe apresentar o mecanismo de tomada de decisão. Esse mecanismo é uma estrutura de trato das informações, que conhece as suas próprias habilidades - do humano virtual - ou os recursos disponíveis para buscar cumprir os objetivos através de uma ação ou intervenção no ambiente.

O mecanismo de tomada de decisão é alimentado pelo processo descrito até então (Racionalização e Memória), o que pode vir a ser alterado com agregações ou exclusões com o intuito de promover uma melhor consistência da mente virtual. Sendo assim, a tomada de decisão, que é consideravelmente modulada pelos objetivos e pela personalidade, opta por interferir no ambiente por meio de seus atuadores, o que acaba se refletindo na concretização de uma ação.

\subsubsection{A Atuação}

A atuação em estruturas reais como robôs envolve todo um processo de Engenharia Mecatrônica para que os seus atuadores interajam com o ambiente, no caso real. Contudo, como o contexto se restringe aos humanos virtuais este módulo do comportamento se restringe a promover animações gráficas e alterações no escopo da simulação que controla o posicionamento dos personagens, e que é observado (fotografado) pelo processo gráfico que gera as sucessivas imagens da animação. 
A modelagem das animações consiste em trabalhar os moldes tridimensionais envolvidos levando-se em conta colisões, limitantes de movimento como é o caso dos graus de liberdade presentes nas articulações dos humanos virtuais, etc.

\subsubsection{Humanos Virtuais com Comportamento Social}

Os humanos virtuais com comportamento social possuem toda a autonomia e a adaptação comum aos humanos virtuais autônomos, porém necessitam de mecanismos de comunicação mais desenvolvidos, bem como ferramentas para lidar com situações que acarretem em conflitos sociais.

Outro aspecto importante que está associado diretamente com a idéia de comportamento social é o conceito de sociedade, onde todos os seus integrantes estão comprometidos com algo; ou seja, que exista um interesse comum a todos. Esse aspecto e alguns outros típicos da teoria de Sistemas Multi-Agentes exigem que esse tipo de humano virtual desenvolva habilidades sociais para conciliar os seus objetivos pessoais com os sociais.

Tais habilidades sociais demandam de informações e conhecimento, seja de caráter individual ou coletivo. Assim, os humanos virtuais necessitam manipular esses níveis de informações (Intenções, Crenças, Conhecimento), bem como, possuir uma estrutura ou hierarquia de agente compatível com seus propósitos e condizente com sua situação no ambiente e sociedade em que vivem (Musse, 2001a).

\subsection{Conclusões}

O capítulo contribuiu para a pesquisa de modo a propiciar conhecimento relacionado aos aspectos de interface de simulação. As premissas básicas da Realidade Virtual (interação, envolvimento e imersão) serão acrescidas ao projeto em trabalhos futuros.

Os humanos virtuais, sob o aspecto de representação gráfica também serão desenvolvidos e incorporados posteriormente ao projeto, dada a sua complexidade. Inicialmente, o projeto contará apenas com uma interface bidimensional com o intuito de validar o modelo aqui proposto. Finalizada esta etapa, pretende-se modelar um ambiente virtual e imersivo dotado de interação ativa para permitir aos usuários 
uma comunicação com os personagens virtuais da simulação. Dessa forma, poderão ser estudados e comparados os resultados da interferência ocasionada. 
"Je pense, donc je suis"

"Ego cogito, ergo sum sive existo"

"Penso, logo existo"

[René Descartes]. 
$\mathrm{O}$ projeto de pesquisa, denominado de $\mathrm{V} 1 \mathrm{~V} 0$, busca apresentar um modelo de comportamento para humanos virtuais. Esse modelo desenvolvido é especialmente voltado para os aspectos da incerteza, ou seja, informações insuficientes ou incompletas sobre o ambiente.

Através desse modelo espera-se que os humanos virtuais desenvolvam um comportamento adaptativo na sociedade. Inicialmente haveria pouca ou nenhuma certeza sobre o ambiente, entretanto, em decorrência de sua experiência de vida, esses personagens viriam a possuir um conhecimento mais maduro e certo.

\subsection{Especificação do Projeto}

A concepção do modelo de comportamento cognitivo envolveu algumas áreas que definiram a abordagem da pesquisa, como: Vida e Inteligência Artificial, além de Realidade Virtual, onde as duas primeiras áreas contribuíram significativamente para o desenvolvimento do modelo e a última, para a definição de aspectos da interface e interatividade da simulação.

\subsubsection{Análise Através do Contexto de Vida Artificial}

Em Vida Artificial pode-se enquadrar uma pesquisa através de conceitos primordiais, como: Filogenia e Filogênese, Ontogenia e Ontogênese e por fim, a Epistemologia. Desse modo, o contexto do trabalho apresentado na Figura 16 evidencia a relevância do conhecimento para a alimentação do modelo de comportamento.

O projeto parte de uma estrutura humana bem concebida, ou seja as informações dispostas no código genético e suas manifestações (Filo) não são manipuladas na pesquisa (Filo). Já alguns aspectos voltados ao indivíduo estarão sendo observados como por exemplo, a experiência de vida do personagem virtual (Onto). No entanto o período abrangido pela simulação não caracteriza situações típicas de aprendizado, no sentido mais amplo, mas sim de reconhecimento e tomada de decisão. Serão observados e analisados os fatores relacionados ao conhecimento (Episteme), a manutenção das informações do humano e como isso influencia o seu comportamento na sociedade. 


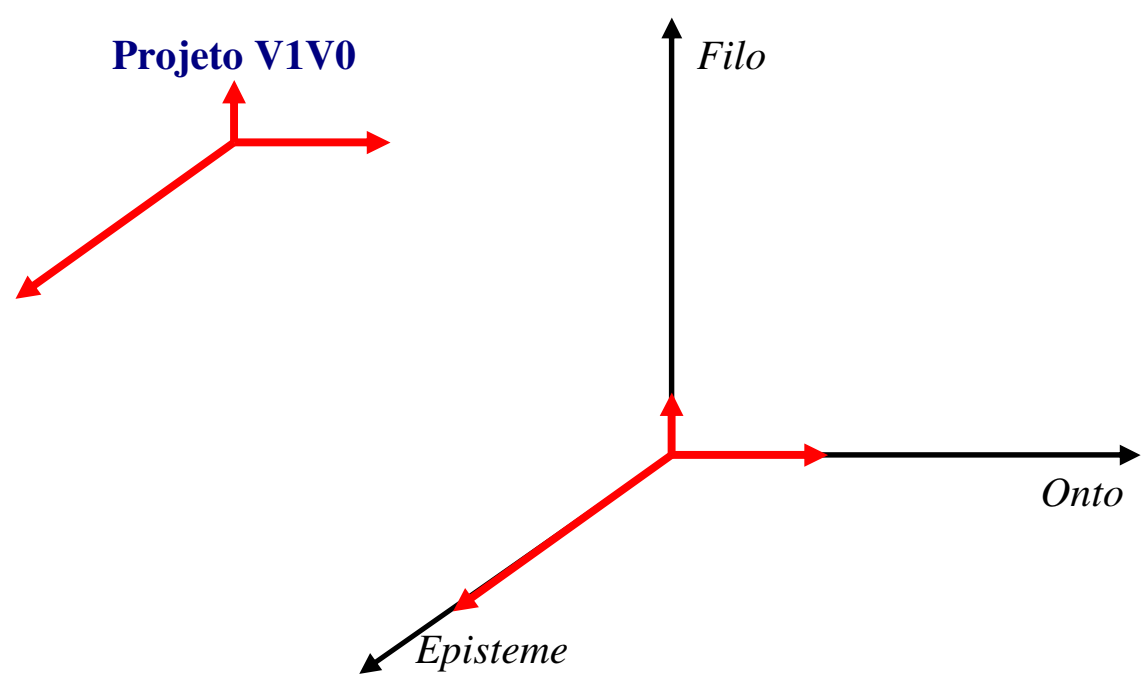

Figura 16: Espaço tridimensional contextualizando o projeto V1V0 em Vida Artificial.

\subsubsection{Modelo Fundamentado em Inteligência Artificial}

A Inteligência Artificial, em especial a que segue modelos distribuídos e que trata de agentes, oferece suporte para a pesquisa através das características do ambiente e da arquitetura utilizada para que o personagem desenvolva o seu comportamento na simulação. Além disto, os mecanismos de comunicação entre os humanos virtuais também são abordados por este paradigma.

\subsubsection{Características do Ambiente Desenvolvido}

$\mathrm{O}$ ambiente tem um papel fundamental nas simulações, pois todo o desenvolvimento está intimamente relacionado com a interação estabelecida entre o ambiente e os seus personagens, além das informações que decorrem desses processos. Sendo assim, o ambiente foi modelado para promover um comportamento autônomo (a cada personagem mantendo o seu próprio conhecimento), se caracterizando por ser:

Parcialmente Observável: os humanos virtuais não têm acesso a todas as informações relativas ao ambiente, exigindo que sua arquitetura (do agente) incorpore a habilidade de desenvolver um conhecimento interno;

Estocástico: os estados futuros do ambiente são incertos, pois dependem da atuação de múltiplos personagens, além da simulação decorrer de uma dinâmica integrada associada a vários parâmetros sobre os quais não se tem controle como 
temporização de diversos cálculos (podendo neste contexto ser considerados aleatórios);

Episódico: a atuação dos humanos possui uma repercussão imediata e instantânea, que acaba se diluindo ao longo do tempo, tornando desnecessária a aplicação do conceito de planejamento, já que o efeito das ações se restringe aquele determinado instante ou a momentos futuros bastante próximos (curto horizonte de tempo);

Dinâmico: a cada instante o estado do ambiente é alterado e exige dos humanos uma constante observação das alterações ocorridas, o que os obriga a estarem periodicamente re-avaliando o seu conhecimento interno;

Discreto: o aspecto temporal no ambiente é plenamente discretizado, ou seja, alterações no estado do ambiente e a atuação dos personagens ocorrem em unidades discretas de tempo;

Multi-agente: o ambiente é integrado por vários humanos que interagem entre si, desenvolvendo um comportamento social simples;

Competitivo: como os personagens possuem um objetivo na sociedade, sempre que este é alcançado ele é recompensado, entretanto, a modelagem dessa dinâmica prevê ganhos e perdas com o intuito de equilibrá-la, assemelhando-se a um sistema presa-predador.

\subsubsection{Arquitetura do Agente}

Partindo-se das características apresentadas do ambiente, a arquitetura utilizada para lidar com esse cenário foi a dos Agentes baseados em Objetivos. Esta arquitetura permite ao humano lidar com o Ambiente Parcialmente Observável (APO) e ainda se posicionar através das ações moduladas pelo seu objetivo maior.

A arquitetura pode ser descrita distintamente em três módulos: Percepção, Cognição e Atuação (Figura 17). Os estímulos detectados pela Percepção representam as informações que o humano consegue observar (ter acesso). Tais informações, denominadas de Fatos, estarão vinculadas a uma parte do meio externo. 
Já a outra parte das informações, as indisponíveis, seriam tratadas pela Cognição. Estas informações do ambiente cujo controle é desenvolvido pelo personagem correspondem ao seu Conhecimento Interno (CI). O conhecimento interno juntamente com o objetivo do humano estaria auxiliando na tomada de decisão. Por fim, atrelado a esse desenvolvimento cognitvo, a Atuação responde pela efetuação das ações do personagem no ambiente de acordo com as decisões tomadas no módulo anterior.

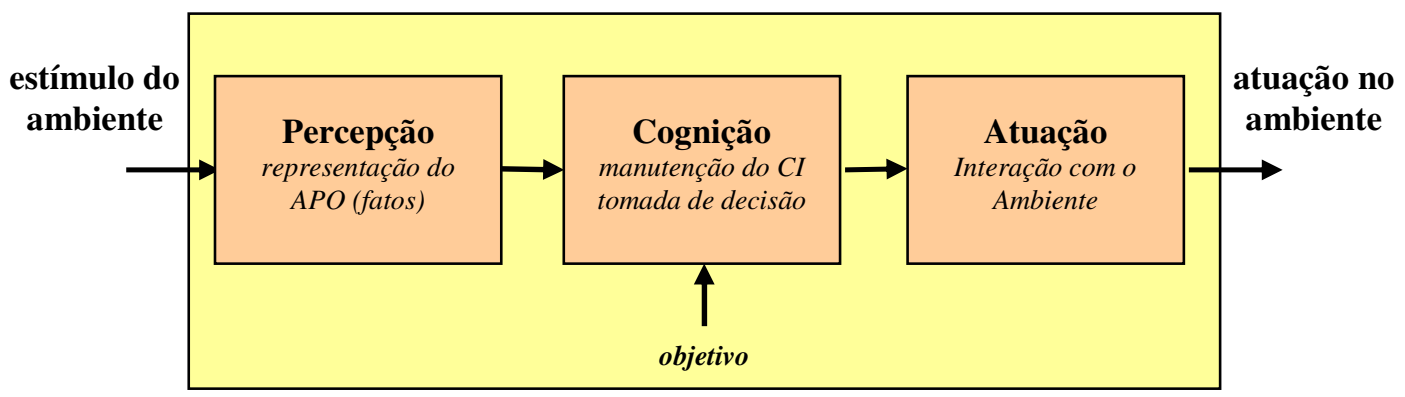

Figura 17: Framework utilizado como base para o desenvolvimento do modelo do projeto.

\subsubsection{Raciocínio Probabilístico como Processo Cognitivo}

Tomando-se como base a arquitetura descrita para os personagens, cabe destacar o processo cognitivo de manutenção do conhecimento interno. Essa manutenção, que é realizada com base em um modelo pré-definido de como os estados do ambiente parcialmente observável podem ser alterados ao longo do tempo, utiliza técnicas de raciocínio probabilístico, em particular, a Teoria de Bayes (Cavalhieri, 2005), (Rodrigues, 2006).

A teoria bayesiana aplicada ao processo consiste em observar os eventos ocorridos no ambiente (Fatos), e relacioná-los com o conhecimento interno. Este conhecimento é integrado pelas informações indisponíveis (num primeiro instante), resultando na geração de Crenças.

O relacionamento entre os fatos, as informações a serem desenvolvidas do mundo (Crenças) e a própria influência desse conhecimento interno na tomada de decisão do humano estão agregados ao processo cognitivo (Figura 18). A consequiência dessa estruturação repercute no processo de inferência bayesiano que é consolidado através do êxito ou fracasso no desenvolvimento da atuação. 


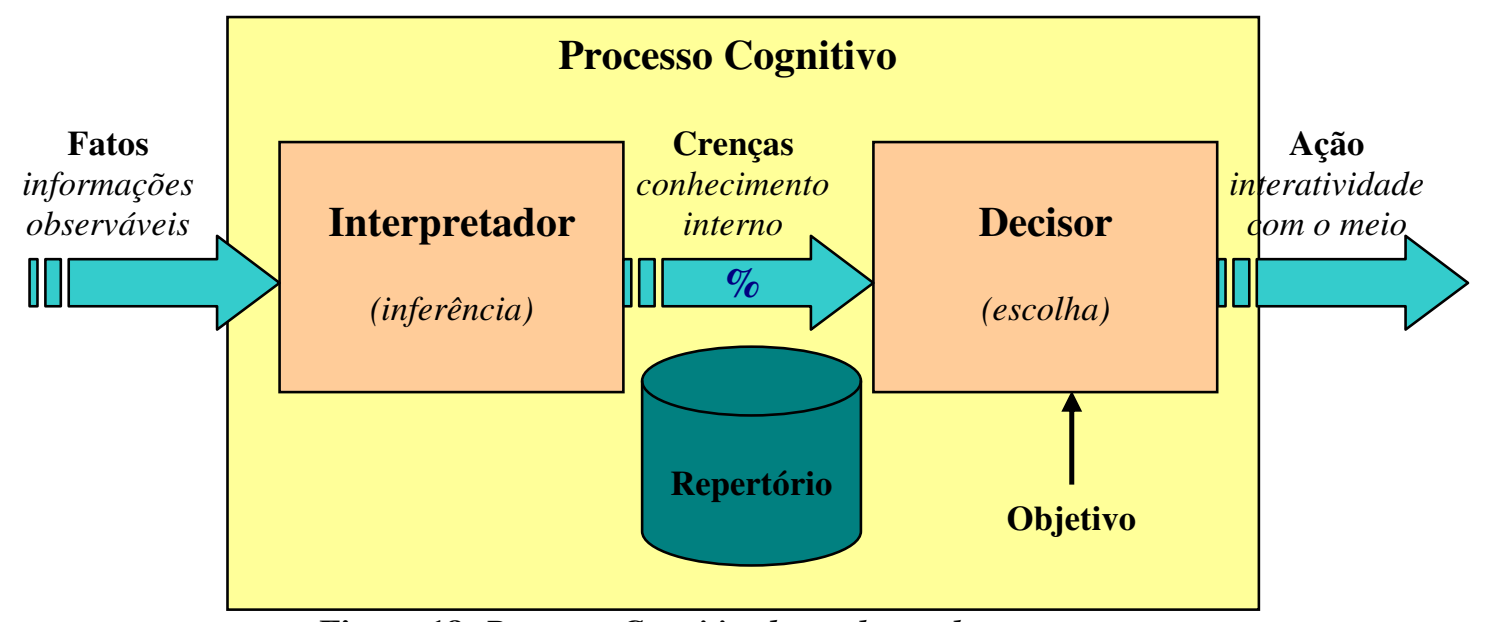

Figura 18: Processo Cognitivo baseado em duas etapas.

\subsection{Arquitetura do Agente}

A arquitetura é formada pelos segmentos de Percepção, Cognição e Atuação. Cada um desses segmentos possui um conjunto de atribuições que permitem o seu funcionamento, tendo em vista um determinado conjunto de entradas e saídas.

Algumas dessas atribuições decorrem dos aspectos de simulação que serão observados, como no caso da Cognição: o objetivo do humano virtual na sociedade e o relacionamento desse parâmetro com o seu conhecimento interno (Crenças). Desta forma, pode-se destacar que o comportamento do personagem estará intimamente atrelado ao seu objetivo, como valores dos níveis de certeza das crenças, por exemplo. A seguir são descritos os segmentos da arquitetura e as suas atribuições.

\subsubsection{Percepção}

A Percepção é o módulo responsável por fornecer informações externas ao personagem, desempenhando uma função de observação e aquisição de informações sobre o ambiente. Este processo permite à Cognição representar internamente informações complementares ao ambiente.

A operação deste módulo é auxiliada por uma entidade externa à arquitetura do agente do humano virtual. Essa entidade é única no ambiente, sendo responsável pelo fornecimento dos dados que servirão de parâmetros nos processos seguintes. Tal 
entidade cuja denominação que melhor a descreve é Oráculo ${ }^{\mathbf{1 6}}$; é consultada pela percepção. Como resposta a uma solicitação, o oráculo informa ao módulo os dados de natureza espacial, como por exemplo: objetos espaciais dispostos no ambiente, suas coordenadas, possível direção, etc.

\begin{tabular}{|c|c|c|c|c|}
\hline Nome & Cor & Direção & Distância & Timestamp \\
\hline
\end{tabular}

Tabela 5: Descrição dos parâmetros que compõem um Fato.

O módulo da percepção recebe esses dados e realiza um tratamento para depois organizá-los sob um formato criado para o sistema, sendo essa organização denominada de Fato (Tabela 5). O tratamento realizado pela percepção consiste em transformar os dados “crisps", ou seja, números, em dados naturais, que são constituídos por rótulos lingüísticos (símbolos) associados a faixas de valores ou espectros.

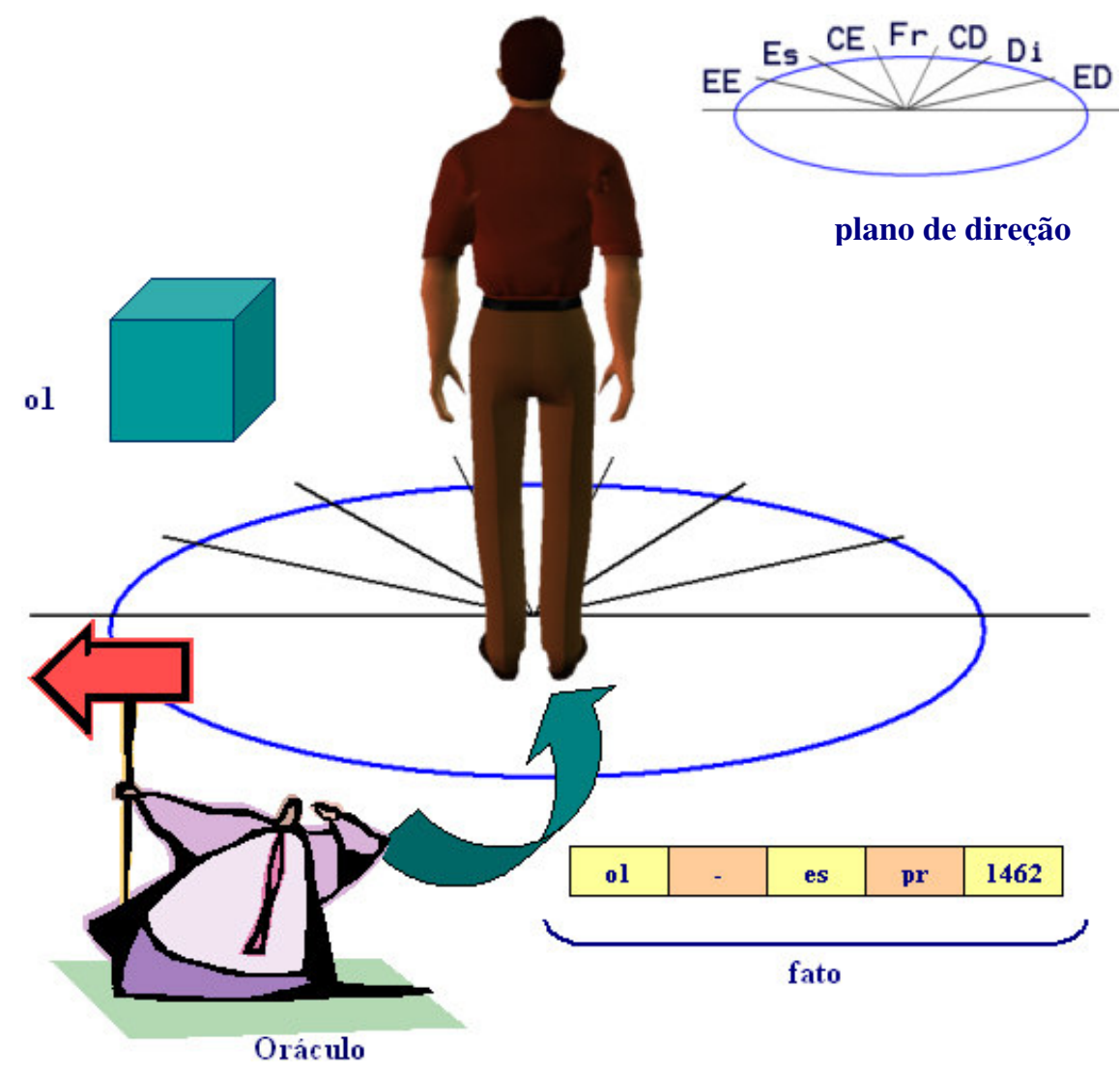

Figura 19: Comunicação entre o humano e o oráculo.

\footnotetext{
${ }^{16}$ Oráculo: entidade de amplo acesso às informações referentes ao ambiente tridimensional. Talvez, uma consideração interessante de se fazer seria a de que o oráculo apresenta as características de onisciência e onipresença no sistema.
} 
Após esse tratamento, os dados são estruturados sob a forma de Fatos que servirão como informações relativas à representação do mundo parcialmente observável. Com base nessas informações é que o módulo seguinte (cognitivo) irá manipular uma representação interna das informações que o personagem não consegue observar num primeiro instante.

A estrutura denominada de Fato é composta por cinco parâmetros relacionados ao meio externo. O primeiro parâmetro é o nome do objeto ou humano detectado, que será generalizado como ator da cena gráfica. O segundo está relacionado à cor da roupa utilizada pelo personagem. O terceiro é a direção em que tal ator se encontra quando considerado do ponto de vista de quem o observa (Figura 19). O quarto é a distância entre o ator e o observador e finalmente o quinto é um marcador de tempo ("timestamp"), ou seja, um parâmetro que marca o tempo em que o fato foi detectado para análise da Cognição.

\subsubsection{Cognição}

A Cognição, que é auxiliada pela Percepção através do sensoriamento do ambiente virtual e pela atuação que age neste ambiente conforme solicitações do presente módulo. Para isso, o módulo cognitivo opera de acordo com o modelo descrito na Figura 18.

O modelo cognitivo implementado é baseado em uma modelagem que representa internamente como o mundo externo opera e possui ainda, parâmetros (objetivos) que direcionam as suas ações. Assim, o funcionamento cognitivo pode ser descrito em duas etapas: a primeira é responsável pela estimação do provável papel desempenhado pelo personagem identificado, e a segunda é a própria tomada de decisão com base nas informações geradas pela primeira etapa.

A seguir serão apresentados os principais conceitos e componentes envolvidos pela estrutura cognitiva, contudo trata-se de uma visão "top-down"; ou seja, inicialmente exibida uma abordagem geral que será melhor detalhada na seqüência. 


\subsubsection{Interpretação do Ambiente}

O processo cognitivo é iniciado com a interpretação dos fatos e é essa a tarefa que compreende a primeira etapa do módulo cognitivo. O componente Interpretador recebe o fato da Percepção e identifica cada segmento que compõe essa estrutura informacional. Uma vez separadas estas são analisadas para que o Interpretador busque no Repertório ${ }^{17}$ os dados relacionados ao fato tratado. Assim, o componente Interpretador atualiza todas as Crenças com base nas informações trazidas pela ocorrência do fato.

O processo de atualização das crenças armazenadas no repertório compreende algumas técnicas e cálculos (raciocínio probabilístico) de modo a representar e manipular não apenas as informações geradas, mas principalmente a incerteza a elas vinculadas.

Na simulação esse processo de interpretação está atrelado à forma com que o ambiente é constantemente alterado. Para isso, a cognição do personagem precisa ter um modelo interno que associe os fatos às crenças e posteriormente a uma ação desejada (objetivo).

\subsubsection{Processo de Tomada de Decisão}

Uma vez que o repertório tenha sido atualizado, a segunda etapa está apta a iniciar o seu funcionamento e assim, concluir o processo cognitivo. O Interpretador propaga para o Decisor o nível de certeza da crença mais relevante ao fato detectado e este componente de decisão utiliza o respectivo nível de certeza para ponderar as suas possíveis ações.

Através da modelagem do objetivo do personagem na sociedade, o seu Decisor tem conhecimento da relação direta entre papel desempenhado pelos demais personagens e a ação preferível a ser tomada. A partir desse conhecimento o Decisor calcula as probabilidades das ações a serem efetivadas mediante o processamento cognitivo até então realizado.

\footnotetext{
${ }^{17}$ Repertório: no contexto do presente trabalho entende-se como o conjunto de dados referentes ao cálculo das crenças (processo de Bayes), incluindo os insumos e os produtos deste processo.
} 
A distribuição de porcentagens, inicialmente seria equiprovável, contudo, ela sofrerá influencias vindas do nível de certeza da crença daquele instante. A ação relacionada diretamente a crença em questão, seria redistribuída ou acrescida com base em seu nível de certeza (ponderação). Detalhes sobre este procedimento serão apresentados à frente.

Uma vez definidas tais porcentagens, o Decisor efetuaria um sorteio das possíveis ações, ponderado pelas suas respectivas distribuições de probabilidade. Após esse sorteio baseado na Roleta de Monte Carlo, a ação é designada ao módulo de Atuação. Entretanto, o processo de decisão só é concluído com o repasse de uma informação que notifique se a ação foi ou não realizada com sucesso pela Atuação. $O$ repasse dessa informação garante ao processo cognitivo uma análise de correção dos valores dos parâmetros que integram a arquitetura do agente.

\subsubsection{Atuação}

Com o Repertório sendo atualizado pelo Interpretador, que acaba constituindo a primeira etapa, o módulo da Cognição, através do Decisor (segundo plano de funcionamento), emite uma ação (escolhe uma ação de acordo com o estado do ambiente) a ser efetivamente realizada pela Atuação.

O módulo de Atuação é responsável pela manipulação dos chamados atuadores conforme a ação definida pelo estágio anterior da arquitetura do agente, permitindo ao personagem interagir com o ambiente e promover modificações no cenário local conforme seus interesses pessoais.

Para fazer isso, a Atuação possui uma biblioteca de animações que a permite efetuar as ações encaminhadas. Essa biblioteca de animações que o módulo utiliza é compreendida por informações organizadas que determinam como manipular os atuadores. Este módulo apresenta características fortemente relacionadas ao contexto gráfico, uma vez que a interação dos personagens como ambiente se restringe ao escopo visual, enquanto que os módulos anteriores se encarregam de aspectos direcionados ao efetivo controle destes recursos. 


\subsection{Representação e Manipulação da Incerteza}

Após o entendimento da Cognição como um todo, e tendo-se em mente os dois planos de funcionamento (Interpretação do Ambiente e Tomada de Decisão), é relevante destacar o desenvolvimento da proposta da pesquisa para atacar os objetivos descritos inicialmente. Assim, buscou-se propiciar ao humano virtual a habilidade em lidar com informações imprecisas ou ruídos, através da exploração da Teoria de Bayes.

O papel da teoria bayesiana no modelo da arquitetura do agente consiste em mensurar a incerteza agregada às informações geradas com base na percepção, e que servirão de parâmetro para que o humano venha a interagir com o ambiente. A medida da incerteza, que está vinculada a uma determinada informação, é abordada no projeto como Crença (Cavalhieri, 2005), (Netto, 2005a).

No contexto desta pesquisa, a crença pode ser descrita como uma informação que descreva o quanto seu portador acredita no fato a ela associado, e cujo valor possa ser determinado pelo cálculo bayesiano. O cálculo desse nível de certeza da crença baseia-se no teorema de Bayes apresentado na Figura 20.

$$
P(H / e)=\frac{P(e / H) * P(H)}{P(e)}
$$

Figura 20: Teorema de Bayes.

Onde $H$ é a hipótese $e$ é a evidência. No contexto desta pesquisa a evidência é dada pelo fato e a hipótese seria a crença. Assim, tem-se a adequação das variáveis para a fórmula da Figura 21.

$$
P(c / f)=\frac{P(f / c) * P(c)}{P(f)}
$$

Figura 21: Expressão de Bayes adaptada. 
Como a probabilidade $\mathrm{P}$ da crença $c$, dada a ocorrência do fato $f$, está vinculada ao nível de certeza da crença, talvez este nível seja melhor descrito através da expressão (Figura 22):

$$
N C(c / f)=\frac{I(f / c) * V c}{V f}
$$

Figura 22: Expressão proposta para cálculo da certeza através da teoria de Bayes.

O parâmetro $\mathbf{I}(\mathbf{f} / \mathbf{c})$ pode ter seu significado descrito como a influência exercida no fato $f$ pela crença $c$, ou seja, o quanto de informação a ocorrência do fato é condicionada pela crença.

A avaliação do I(f/c) racionaliza-se de modo inverso, partindo-se da certeza absoluta da crença, qual seria o tamanho da influência condicionada pelo fato. Esse parâmetro é fundamental na expressão probabilística, pois é nele que reside a inserção do ruído no cálculo. Uma outra consideração é que o índice seria o parâmetro que verdadeiramente relaciona os demais parâmetros independentes no teorema bayesiano.

A contribuição com o ruído ou incerteza, atrelada à expressão bayesiana, é obtida pelo modo como esse parâmetro está articulado com os demais. A influência I(f/c) apresenta um caráter redutor para a probabilidade a priori da crença (parâmetro independente e incondicional). Essa redução decorre da relação obtida pela influência entre fato e crença e vice-versa - o chamado likelihood ${ }^{18}$.

Conforme essa influência varie ${ }^{19}, \Delta \mathrm{I}(\mathrm{f} / \mathrm{c})$, de modo a percorrer uma curva descendente, a probabilidade a priori da crença é reduzida na mesma proporção. Já no caso de um comportamento dessa influência próximo dos $100 \%$ (plena

\footnotetext{
${ }^{18}$ A título de caso prático, pode-se explicitar o seu funcionamento pela idéia: "na certeza da crença c, para o caso do nível situar-se de antemão em 100\%, qual seria o tamanho da contribuição dada pela informação (fato) f?".

${ }^{19}$ Assim como todas as demais variações dos parâmetros da expressão bayesiana do projeto V1V0, a variação da influência exercida pelo fato na crença é compreendida pelo intervalo [0, 1]; sendo que os valores próximos a 0 representariam quase ou nenhuma convicção por parte do humano virtual com relação àquela determinada crença, ao passo que, os valores próximos a outra vertente (1) representariam uma elevada convicção.
} 
convicção), o valor do nível de certeza da crença passaria a ser praticamente definido pela probabilidade clássica ${ }^{20}$.

Para uma melhor análise promovida pelo humano virtual, os parâmetros incondicionais ou independentes são determinados a partir das funções que os calcula. Tais funções, no projeto, recebem a denominação de viés (viés de crença e de fato).

$$
V_{C}(t)=\frac{C_{A \text { Priori }}+V_{C}(t-1)+a}{3}
$$

Figura 23: Expressão proposta para o cálculo do viés de crença.

Em termos práticos o viés, seja ele de crença ou fato, permite levar em consideração alguns aspectos com o intuito de possibilitar uma infraestrutura de base para o processo de determinação do quanto o humano acredita em algo tendo em vista um cenário representado pela Percepção através da lista de fatos.

No caso, o viés de crença (Vc) seria o resultado da consideração dos valores: a priori do nível de certeza da crença, mais o valor desse viés (Vc) no instante anterior (t-1) em acréscimo a um alfa; sendo ainda, esse resultado normalizado pela média dos três parâmetros descritos (Figura 23).

Com esse cálculo é determinado um viés de comportamento bem localizado numa faixa pré-determinada inicialmente em decorrência do nível de certeza a priori, $\mathbf{C}_{\text {apriori }}$ (Figura 24). Esse parâmetro que exibe o conhecimento a priori, talvez, possa ser apontado como uma pseudo personalidade no processo cognitivo desencadeado pela arquitetura do agente e contundentemente seria a sua participação explícita na determinação do quanto o personagem acredita em uma determinada informação. Esse nível a priori é manipulado pela expressão como se fosse uma constante agregada, pois seu valor mantém-se invariável do início ao final da simulação, demonstrando assim, a relevância da personalidade com o modelo cognitivo apresentado.

\footnotetext{
20 A probabilidade clássica é determinada pela relação entre os valores dos parâmetros definidos pela probabilidade da hipótese e a da evidência. Contudo, não existe uma interferência da influência exercida pela ocorrência da evidência.
} 

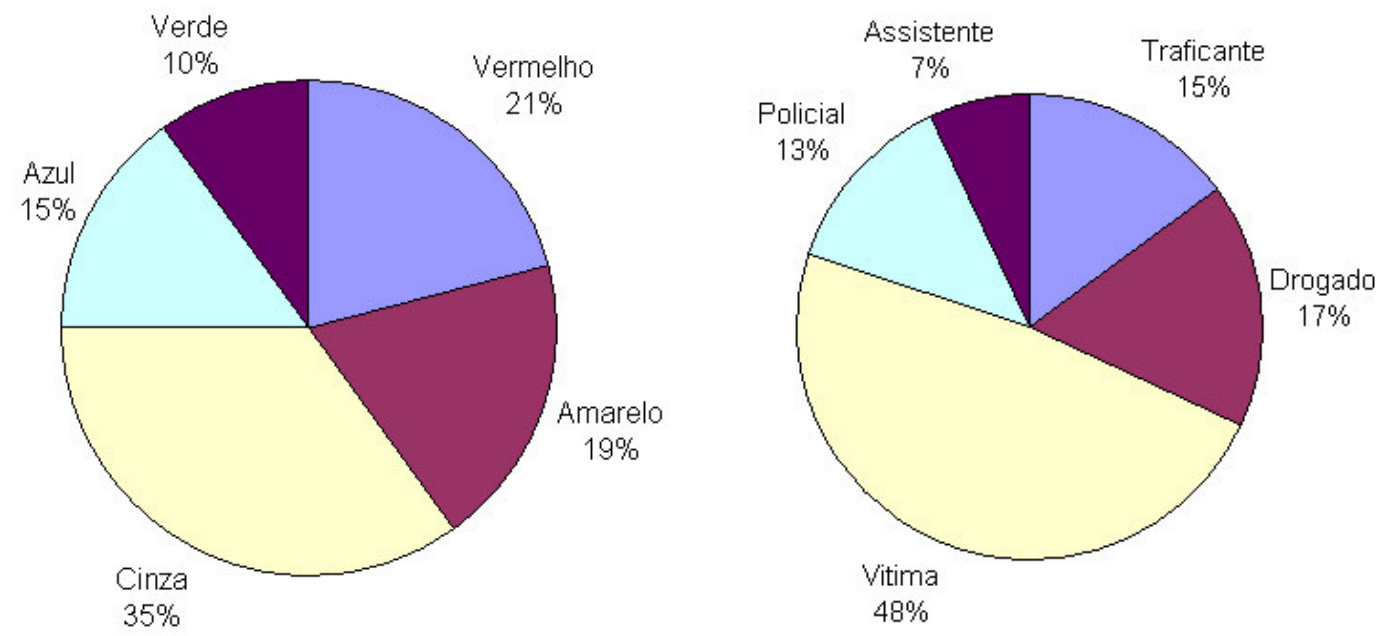

Figura 24: Parâmetros a priori do cálculo bayesiano, Fatos e Crenças respectivamente.

Uma outra característica importante de ser levantada seria a memória, uma vez que o viés sempre levará em consideração o seu valor anterior, Vc (t-1). Essa análise temporal evita oscilações dos níveis de certeza, mantendo uma determinada graduação de seu comportamento.

O último atributo, decorrente da consideração realizada pelo cálculo do viés de crença - o alfa (a), transmite a informação do quão significativa tem sido essa informação (crença) para o seu repertório. Esse atributo é determinado pela relação entre o número de vezes que o nível de certeza (a posteriori) foi maior que as das demais crenças equivalentes (ntop1) e o número de interações ou tempo decorrido até então (t).

Já o processo do outro viés, o Vf, é compreendido similarmente ao Vc. No entanto, seus parâmetros se relacionam diretamente com o fato abordado. $\mathrm{O}$ viés do fato é obtido pela média da soma dos parâmetros do nível de certeza do fato (a priori), pelo valor desse viés (Vf) no instante passado (t-1) e por um beta (b) (Figura 25).

$$
V f(t)=\frac{F_{\text {A Prior1 }}+\operatorname{Vf}(t-1)+b}{3}
$$

Figura 25: Expressão proposta para o cálculo do viés de fato. 
O nível de certeza do fato, $\mathbf{F}_{\mathbf{a}}$ priori, (Figura 24) seria o quanto o humano acredita que possa vir a ocorrer esse dado fato no ambiente. Seria a presença da pseudo personalidade, já que esse parâmetro estaria pré-definido e seu valor seria individual.

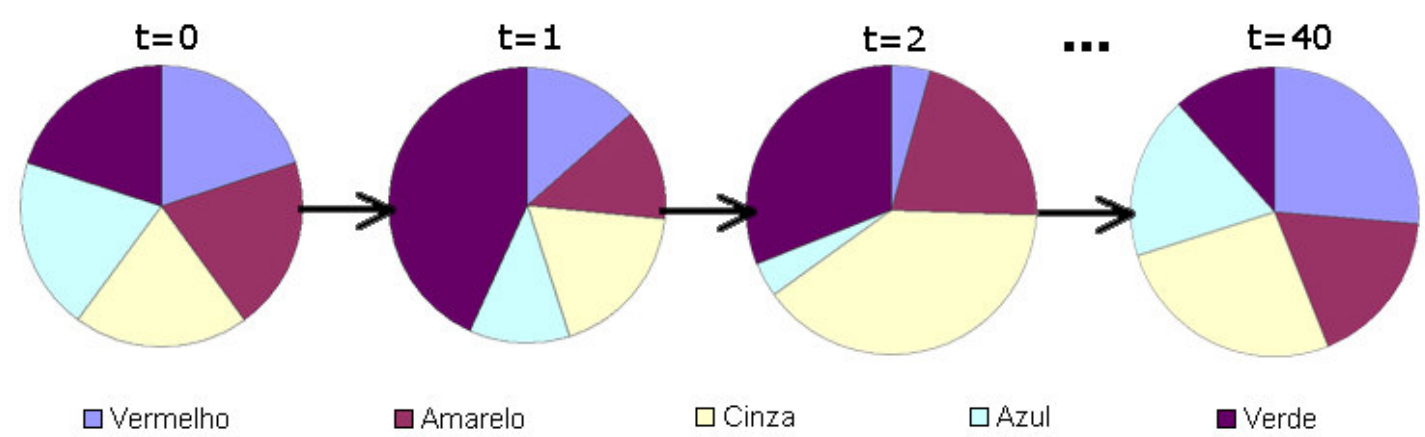

Figura 26: Evolução dos valores do Vf (t) para todos os fatos (cores).

Assim como para o cálculo do viés de crença, o Vf promove uma análise de seu estado anterior (Figura 26), demonstrando que seu estado futuro será sempre determinado, também, pelo seu estado anterior - Vf (t-1).

Fechando o processo de cálculo do nível de certeza da crença, o beta (b) fornece a idéia de frequiência do fato abordado. Essa freqüência acaba então, influenciando o cálculo do viés do fato de modo que os eventos cuja frequiência sejam relativamente superiores aos demais sejam fortalecidos. Esse reforço promovido para os fatos mais freqüentes parte do intento de que seria interessante evidenciar o aumento da certeza por parte do humano virtual da relação existente entre o fato $f$ e a crença $c$.

O processo apresentado para o cálculo da certeza da crença (a posteriori), NC(c/f) é exaustivo, ou seja, se trata de um processo a ser disparado para calcular os níveis de certeza de todas as crenças de porte do repertório do humano com base no fato detectado. Essa atualização dos níveis de certeza garante ao personagem estar com suas informações internas devidamente adequadas ao cenário local, considerando-se ainda a racionalização da participação e da influência de ruídos e incertezas. 


\subsection{Modelo de Funcionamento do Ambiente}

$\mathrm{O}$ modelo de funcionamento do ambiente é fortemente vinculado à dinâmica de simulação, ou seja, às regras de como os estados de um determinado ambiente se alteram e como os personagens podem manipulá-los. Assim sendo, o modelo apresentado acaba descrevendo a simulação elaborada para determinar o ambiente a ser observado.

\subsubsection{Ambiente de Simulação}

A simulação busca recriar um ambiente social e para isso, foi modelada uma dinâmica semelhante ao sistema presa/predador. A dinâmica tem por objetivo evidenciar a habilidade dos personagens em identificar e reconhecer algo e ao mesmo tempo serem capazes de determinar o quão certos estariam.

Os personagens são recompensados ou punidos conforme o seu êxito no alcance de seus objetivos ou delegações. Tais objetivos são determinados a partir do papel que cada humano desempenha na sociedade. Foi proposto como ambiente social uma simulação de narcotráfico simplificada, com papéis específicos atribuídos aos seus personagens. De acordo com esta proposta o traficante tem a delegação de vender entorpecentes, o policial de reprimir o tráfico, o dependente químico de consumir tais entorpecentes, enquanto que o assistente tentaria convencer o dependente a abandonar essa dependência química, e por fim, a vítima que seria por exclusão a ausência das demais delegações (Cavalhieri, 2005), (Netto, 2005a).

Com base nos papéis e nos objetivos da simulação, o modelo de funcionamento do meio externo é determinado a partir do conhecimento relacional, que são apresentados a seguir.

\subsubsection{Conhecimento Relacional}

Um conhecimento fundamental que está presente no modelo é a relação entre fato e crença (Figura 27). Este relacionamento faz um mapeamento entre as informações observáveis e as não-observáveis, o que permite ao humano desenvolver 
expectativas; algo que decorre das suas observações e ao mesmo tempo elaborar as suas concepções individuais do meio externo.

Na simulação um dos parâmetros do fato é relacionado diretamente com a crença, caracterizando-se como um indício (evidência) que permite desenvolver um raciocínio lógico (bayesiano). Este conhecimento decorre do relacionamento, ou seja, dizer a um personagem qual a cor da roupa de outro personagem serve como indício para o primeiro estimar qual o provável papel desempenhado pelo segundo (objetivo).

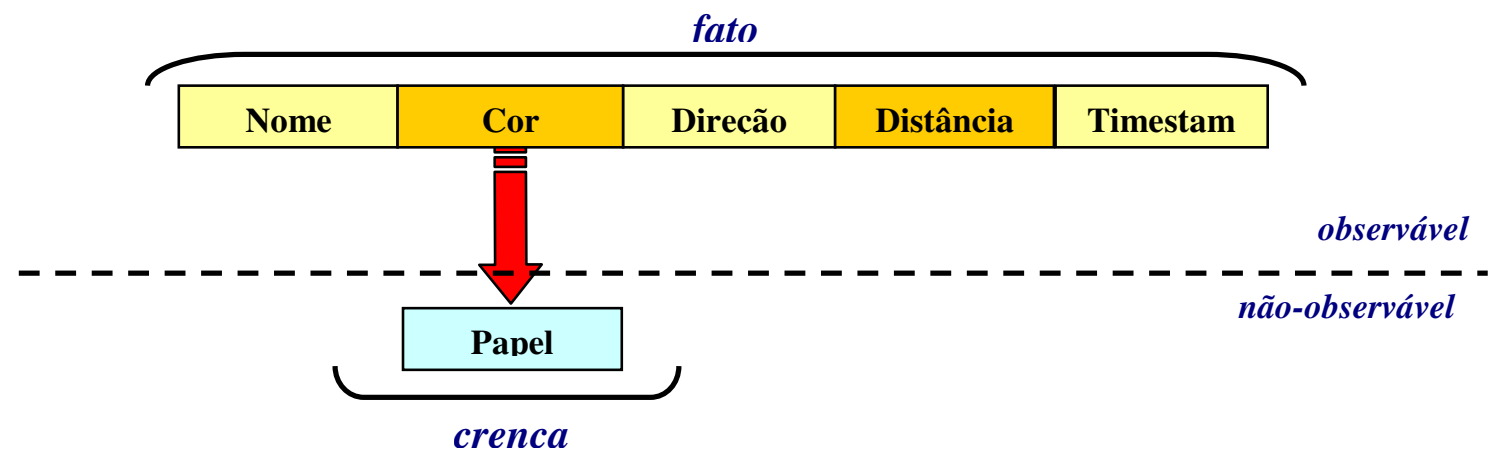

Figura 27: Relacionamento entre fato e crença para desenvolvimento de conhecimento interno.

Esse tipo de relacionamento pode ser interpretado como a ocorrência de uniformes na sociedade. Contudo, mesmo o humano tendo conhecimento desse relacionamento, ele precisa aprender quais valores apresentam um relacionamento mais direto, o que evidencia a chamada Crença Dominante.

A Crença Dominante é a crença com o maior nível de certeza comparativamente as demais crenças. Por exemplo: para o Fato de se observar um personagem com camiseta Vermelha o Interpretador, em decorrência de uma má experiência, poderia ser induzido a destacar a Crença de Drogado como a mais significativa. Logo, ela seria a crença dominante de seu chamado "subset", o que seria um erro mediante a modelagem do sistema.

\begin{tabular}{|c|c|}
\hline Fato & Crença Dominante \\
\hline Vermelho & Traficante \\
\hline Amarelo & Drogado \\
\hline Cinza & Vítima \\
\hline Azul & Policial \\
\hline Verde & Assistente \\
\hline
\end{tabular}

Tabela 6: Relacionamento desejado entre os valores de fato e crença (Dominante). 
Para as situações de erro ocorrerão medidas de com o intuito de corrigi-las, já as situações de acerto, resultarão em incrementos o que acentuaria ainda mais o domínio desta determinada crença frente às outras, configurando assim um incentivo ou gratificação. De acordo com a modelagem, o relacionamento desejado após a convergência da simulação é apresentado na Tabela 6.

\begin{tabular}{|c|c|c|c|c|c|}
\hline Papel/Crença & Traficante & Drogado & Vítima & Policial & Assistente \\
\hline Traficante & Nada & Vender & Flertar & Fugir & Retalhar \\
\hline Drogado & Comprar & Nada & Roubar & Fugir & Fugir \\
\hline Vítima & Fugir & Fugir & Nada & Se proteger & Se aconselhar \\
\hline Policial & Prender & Retalhar & Proteger & Nada & Proteger \\
\hline Assistente & Fugir & Tratar & Aconselhar & Se proteger & Nada \\
\hline
\end{tabular}

Tabela 7: Relacionamento da Ação entre papel (objetivo pessoal) e a crença sobre o observado.

Um outro conhecimento relacional é determinado entre papel e crença dominante, decorrendo na ação a ser tomada. O humano através do modelo de funcionamento sabe como agir com um personagem através da crença naquele humano na sociedade. Assim, um relacionamento direto ("um para um") entre papel e crença dominante pode ser apresentado na Tabela 7.

\subsubsection{Funcionamento do Modelo}

Através do fato gerado na Percepção, o Interpretador cria uma distribuição dos possíveis papeis (nível de certeza das crenças). Após essa criação, é destacado o maior intervalo, ou seja, a crença mais significativa ou de maior nível. De acordo com a Figura 28 corresponderia aos itens 1, 2 e 3.

O Interpretador repassa essa crença e o seu respectivo nível de certeza, que foram alcançados por um processo de caráter Determinístico, ao Decisor. Ele então faz uma redistribuição das probabilidades das ações possíveis. Novamente com base na Figura 28, os itens correspondentes seriam 4 e 5.

O conjunto de ações possíveis é sempre determinado a partir de relações com uma crença. Assim, a ação relacionada à crença de maior nível será privilegiada, pois terá a sua probabilidade aumentada de acordo com o nível de certeza (ponderação).

Uma vez redistribuídas as probabilidades entre as ações, o Decisor realiza um sorteio similar ao processo da Roleta de Monte Carlo, caracterizando esse processo 
de tomada de decisão como Probabilístico (Item 6 da Figura 28). Depois de selecionada a decisão, esta é encaminhada ao módulo de Atuação.

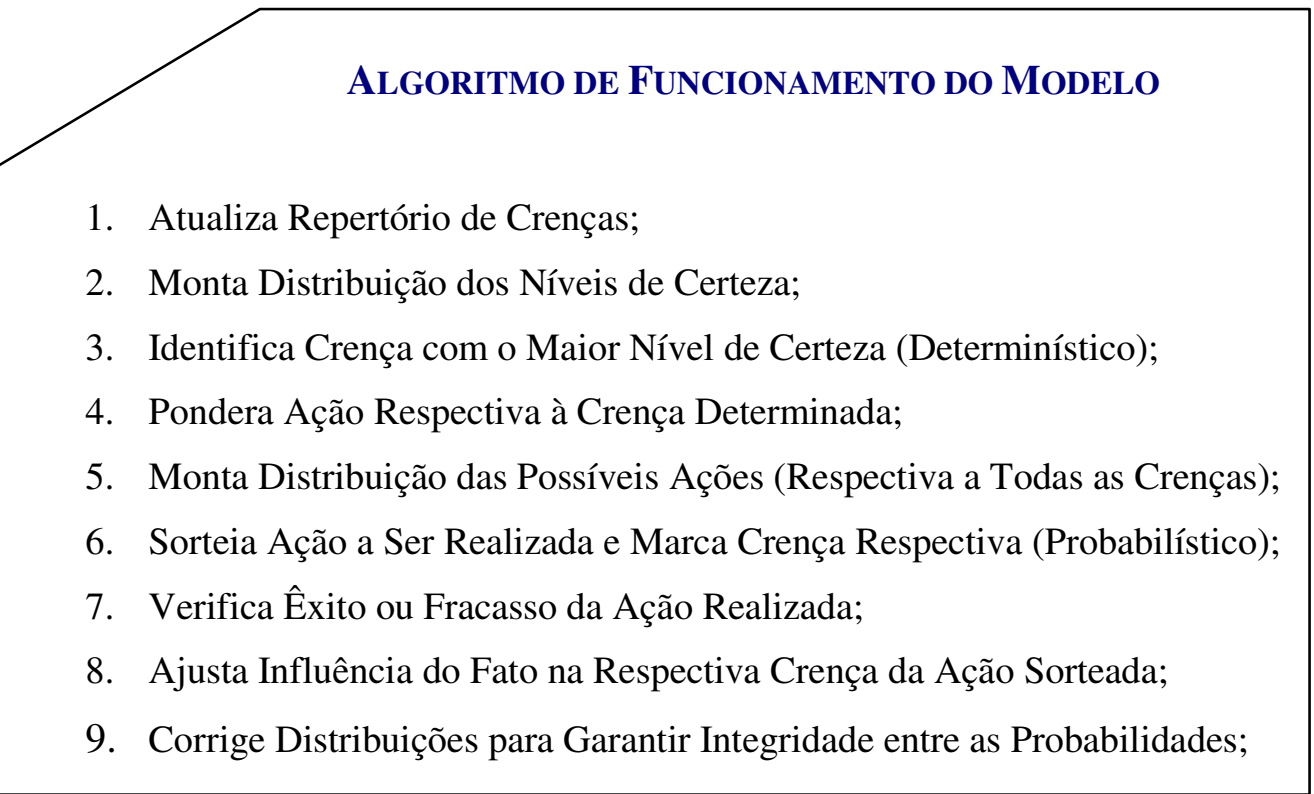

Figura 28: Algoritmo de funcionamento do modelo.

Para finalizar o ciclo cognitivo, o Decisor é informado do êxito ou não no desenvolvimento da ação. Tal medição é alcançada quando a ação é deliberada normalmente, pois caso haja alguma inconsistência a ação não será realizada com sucesso. Para melhor ilustrar a obtenção dessa medida pode-se admitir o seguinte cenário: um traficante identificaria (erroneamente) um policial como drogado e tentaria vender drogas a ele, o que não seria realizado com sucesso.

O resultado é um valor binário semelhante ao verdadeiro ou falso para representar o sucesso ou o insucesso da ação, cabe ressaltar também que este sucesso está apenas condicionado ao fato de se identificar corretamente o papel que o personagem exerce na sociedade.

A informação de êxito ou não permite ao Decisor notificar o Interpretador sobre a relação, $\mathbf{I}(\mathbf{f} / \mathbf{c})$, existente entre o fato detectado e a crença realmente utilizada no processo de tomada de decisão. $\mathrm{O}$ resultado dessa retropropagação permite ao Interpretador corrigir a tabela de influências (Figura 29). Essa correção consiste no decremento ou incremento conforme o fracasso ou o êxito, respectivamente. Tais processos correspondem aos itens 7, 8 e 9 da Figura 28. 
Estes decrementos ou incrementos ocorrem com base em uma constante previamente definida, que serve ainda como um coeficiente da simulação. A constante utilizada ou coeficiente acaba determinando a velocidade de convergência da simulação.

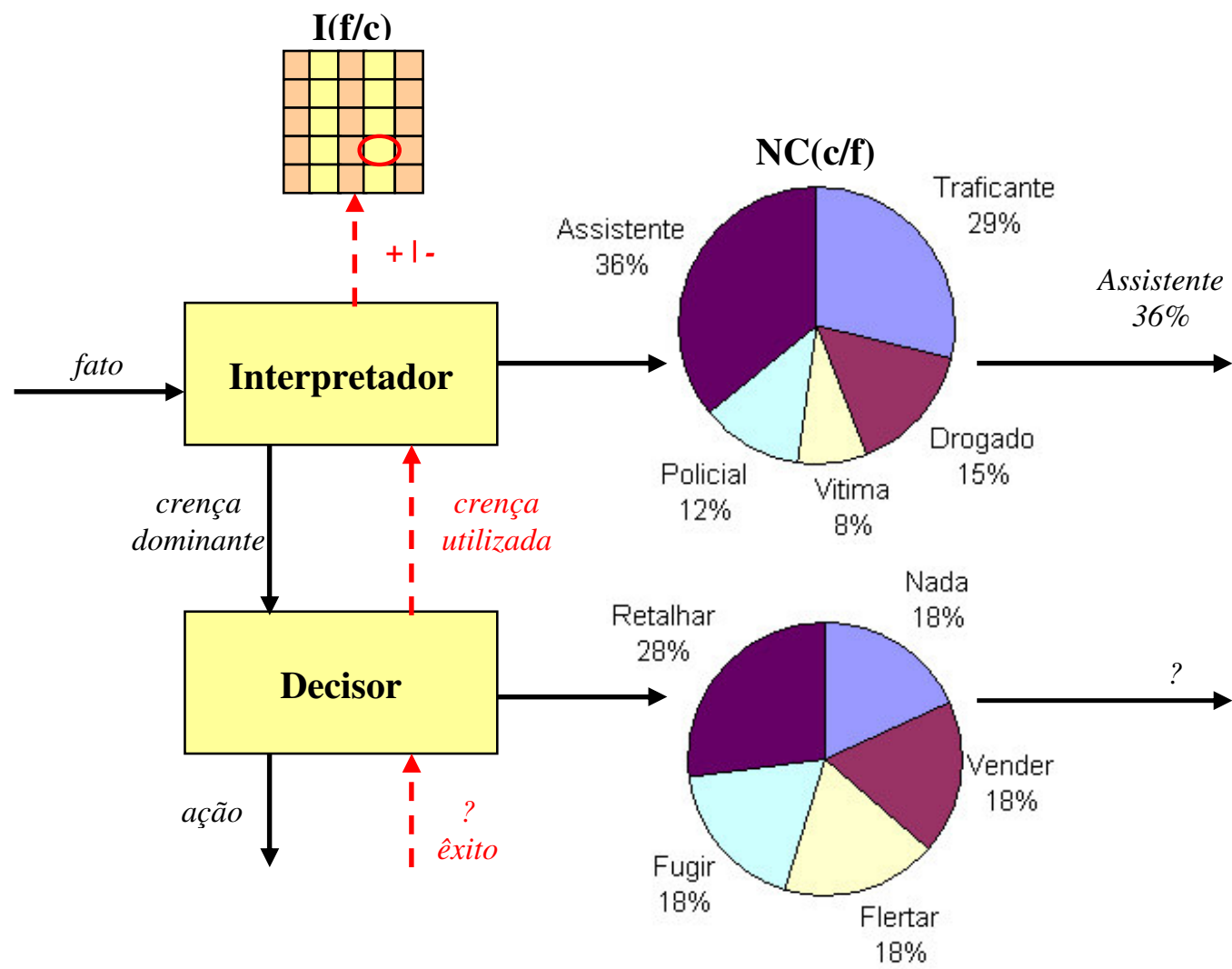

Figura 29: Modelo da Cognição e do funcionamento do Ambiente.

Também é interessante ressaltar que após essas correções nos valores da influência fato/crença, o Interpretador precisa balancear esses incrementos ou decrementos para manter a integridade probabilística. Para isso, o valor da constante usada para incrementar ou decrementar o parâmetro é diluído entre os demais parâmetros de modo que a soma desses valores mantenha-se no exato patamar de $100 \%$ ou 1.0 . 


\subsubsection{Relação entre Papel, Fato, Crença e Ação}

O modelo cognitivo implementado, que se baseia em fatos, crenças e papéis para atuar, pode ser observado sob o aspecto das relações entre estas informações. Assim, de um modo simplificado pode-se adotar uma arquitetura similar ao da "Caixa Preta", sendo um fato $\left(\mathrm{F}_{1}\right)$ o dado de entrada e uma ação $\left(\mathrm{A}_{2}\right)$ a informação de saída (Figura 30).

Ao se abrir esta caixa preta, que representaria o modelo cognitivo, tornaria possível observar o relacionamento exaustivo ( "um para todos”) entre fato e crença e o relacionamento direto ("um para um”) entre crença e ação. Com isso, têm-se atrelado ao fato dois gráficos em forma de pizza: as crenças e as ações respectivamente.

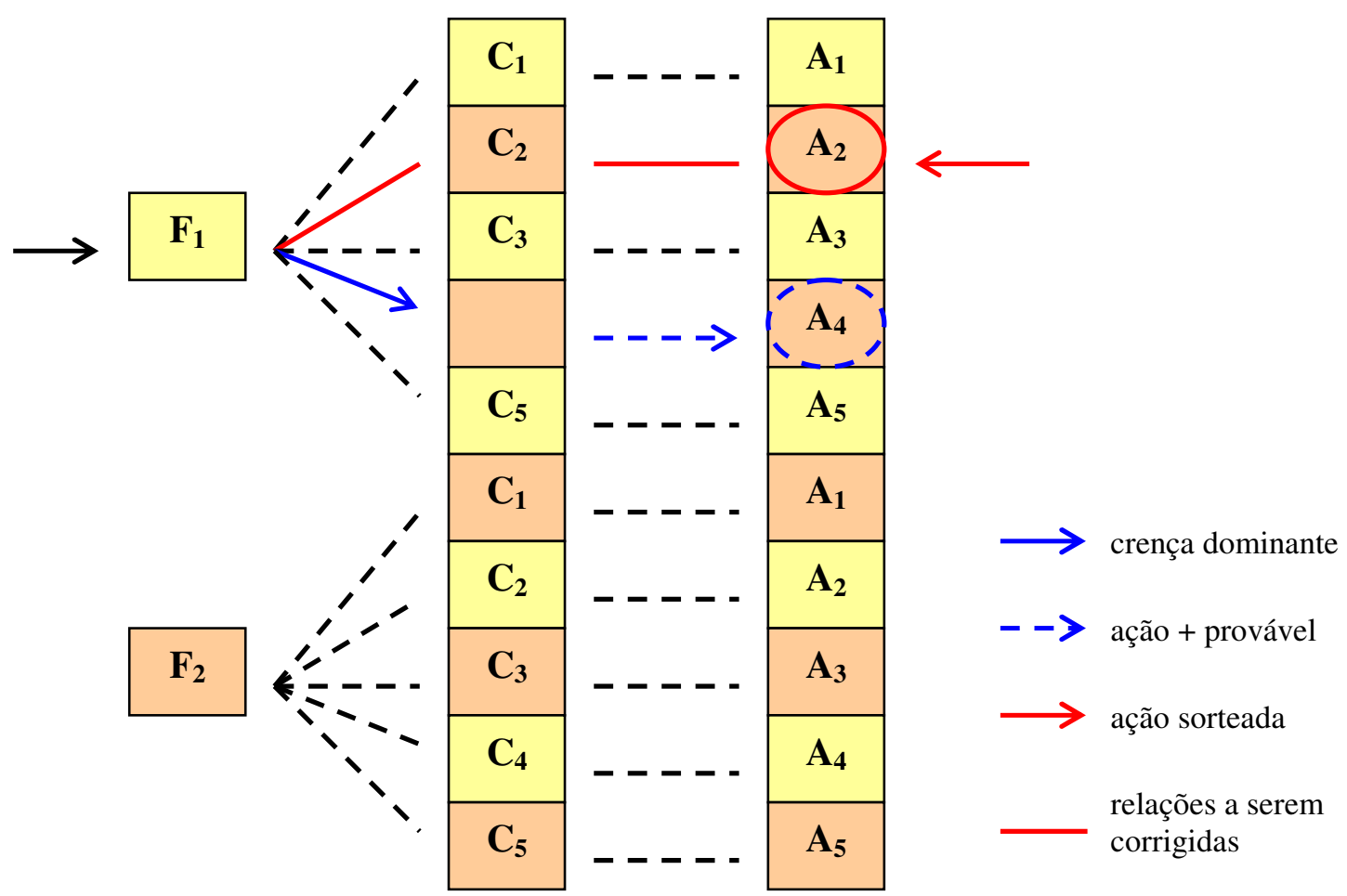

Figura 30: Modelo do relacionamento entre as informações fato, crença e ação.

Como as crenças e as ações possuem um relacionamento direto e exclusivo, ou seja, desde que o personagem identifique corretamente o papel desempenhado por outro humano virtual, este saberá então que ação escolher. Tal afirmação é possível já que para cada crença existe apenas uma ação equivalente, excluindo ai qualquer incerteza de modo direto. Entretanto, o processo de tomada de decisão é probabilístico e decorre de um sorteio, o inserindo em um contexto vago. 
Este sorteio é baseado em porcentagens que refletem a chance das ações serem selecionadas. Sendo, através da ação escolhida, possível reavaliar a relação fato/crença, que é determinada pelo I(f/c).

\subsection{Conclusões}

A integração promovida entre a arquitetura do agente (modelo baseado em objetivos para um ambiente parcialmente observável) e a técnica do cálculo das incertezas (Teoria de Bayes) permitiu a criação de um cenário, no qual foi possível se observar alguns fenômenos sob o escopo de Vida Artificial.

Um desses fenômenos é o desenvolvimento cognitivo realizado pelo Interpretador. O humano virtual ao detectar um outro personagem irá prestar atenção na cor de sua roupa (uniforme) para averiguar como deverá proceder. Como essa averiguação baseia-se numa suposição, a mesma deve ser comprovada, e para isso ele passa por um processo de experimentação ou até aprendizado.

Essa etapa de experimentação e aprendizado consiste em distinguir e relacionar o fato correto com a sua respectiva crença (cor da roupa - papel desempenhado). Tal etapa é efetivada através da aplicação dos métodos de raciocínio probabilístico e determinístico, no caso, a teoria bayesiana.

Um outro fenômeno seria a capacidade de experimentação, o ato do personagem se permitir errar de modo racional e calculado. Essa capacidade de estar aberto a novas experiências é alcançada pelo Decisor que avalia o quanto se tem certeza do papel desempenhado pelo humano observado.

A avaliação decorre da ponderação baseada no nível de certeza da crença mais significativa, ou seja, quanto maior a certeza, maior será a chance dele realizar a ação correta. Entretanto, essa margem de incerteza lhe propicia a ambição por novas constatações do tipo: "e se eu estiver errado, talvez seja melhor experimentar...".

Tal raciocínio pode onerar um pouco o desempenho do personagem, mas a médio e a longo prazo, talvez lhe proporcione uma maturidade capaz de se adaptar frente a alterações e evitando que ele se limite aos seus conhecimentos prévios. Ainda nesse âmbito do conhecimento é interessante ressaltar a habilidade do modelo 
em lidar com um ambiente parcialmente observável, o que é muito comum em aplicações práticas. 


\title{
5 ANÁliSE dOS RESULTADOS DA SiMULAÇÃo
}

\begin{abstract}
"Simbolismo dos Números Pitagóricos: um é a razão, dois a opinião, quatro a justiça, cinco o casamento, dez a perfeição, etc. Um é o ponto, dois é a Iinha, três é a superfície, quatro é o volume. Cosmogonia. O Universo e os Planetas Esféricos. A Harmonia das Esferas"
\end{abstract}

[Pitágoras]. 


\subsection{O Ambiente de Simulação}

O ambiente de simulação da dinâmica de um cenário envolvendo Tráfico de Drogas foi estruturado a fim de agrupar parâmetros e informações a respeito da visualização gráfica, configurações da simulação, arquitetura do agente (Framework), estatísticas e uma área destinada a mensagens do sistema (Figura 31).

\begin{tabular}{|c|c|c|c|c|c|c|c|}
\hline \multicolumn{8}{|c|}{ Applet Viewer: vivo.MainApplet.class } \\
\hline \multicolumn{8}{|c|}{ Applet } \\
\hline Simulacao & \multicolumn{2}{|c|}{ Configurações } & Frai & amework & Estatisticas & Log & Sobre \\
\hline \multicolumn{2}{|c|}{ População: 50} & \multicolumn{3}{|c|}{ Flutuação: 0.15} & \multicolumn{2}{|c|}{ Correção: 0.03} & Inicial: 0.2 \\
\hline \multicolumn{8}{|l|}{ Papéis } \\
\hline \multicolumn{2}{|c|}{ Traficante } & \multicolumn{2}{|c|}{ Drogado } & Vitima & \multicolumn{2}{|c|}{ Policial } & Assistente \\
\hline \multicolumn{2}{|c|}{0.15} & \multicolumn{2}{|c|}{0.22} & 0.3 & \multicolumn{2}{|c|}{0.14} & 0.19 \\
\hline \multicolumn{8}{|c|}{ Fatos a priori } \\
\hline \multicolumn{2}{|c|}{ Vermelho } & \multicolumn{2}{|l|}{ Amarelo } & Cinza & \multicolumn{2}{|c|}{ Azul } & Verde \\
\hline \multicolumn{2}{|c|}{0.21} & \multicolumn{2}{|c|}{0.19} & 0.35 & \multicolumn{2}{|c|}{0.15} & 0.10 \\
\hline \multicolumn{8}{|c|}{ Crenças a priori } \\
\hline \multicolumn{2}{|c|}{\begin{tabular}{|l|} 
Traficante \\
\end{tabular}} & \multicolumn{2}{|c|}{ Drogado } & Vitima & \multicolumn{2}{|c|}{ Policial } & Assistente \\
\hline \multicolumn{2}{|c|}{0.15} & \multicolumn{2}{|c|}{0.17} & 0.48 & \multicolumn{2}{|c|}{0.13} & 0.07 \\
\hline
\end{tabular}

Figura 31: Ambiente de Simulação.

As configurações da simulação, que no ambiente encontram-se no tópico Configurações, apresentam os seguintes parâmetros a serem estipulados:

- o tamanho da população (quantidade de humanos virtuais);

- porcentagem de flutuação em caso de liberdade e individualização desses parâmetros (as probabilidades a priori), onde cada personagem possuiria seus próprios valores destas probabilidades a priori $\left(\mathrm{C}_{\text {apriori }}\right.$, $\left.\mathrm{F}_{\text {apriori }}\right)$;

- regulagem da taxa de correção tanto do relacionamento entre fato e crença, I(f/c), quanto do próprio ajuste do nível de certeza de uma dada crença, $\mathrm{NC}(\mathrm{c} / \mathrm{f})$. Esta regulagem atua em termos práticos na simulação como uma espécie de parâmetro para definir a temperatura e a velocidade do sistema; 
- possibilidade de configurar o instante inicial ( $\mathrm{t}=0$ ), ou seja, estipular se o Vc e o Vf iniciaram em 0, se serão equiprováveis (todos em 20\%) ou ainda, se serão determinados aleatoriamente (-1);

- distribuição dos papéis (quantidade de traficantes, dependentes químicos, vítimas, etc);

- definição das faixas de probabilidades a priori tanto para as crenças quanto para os fatos $\left(\mathrm{C}_{\text {apriori }}, \mathrm{F}_{\text {apriori }}\right)$.

A Visualização Gráfica (Simulação) consiste em uma tela de renderização bidimensional, sendo os humanos virtuais representados inicialmente por círculos coloridos. A cor desses círculos decorre da sua respectiva cor de roupa, determinando assim o seu papel na sociedade (Figura 32).

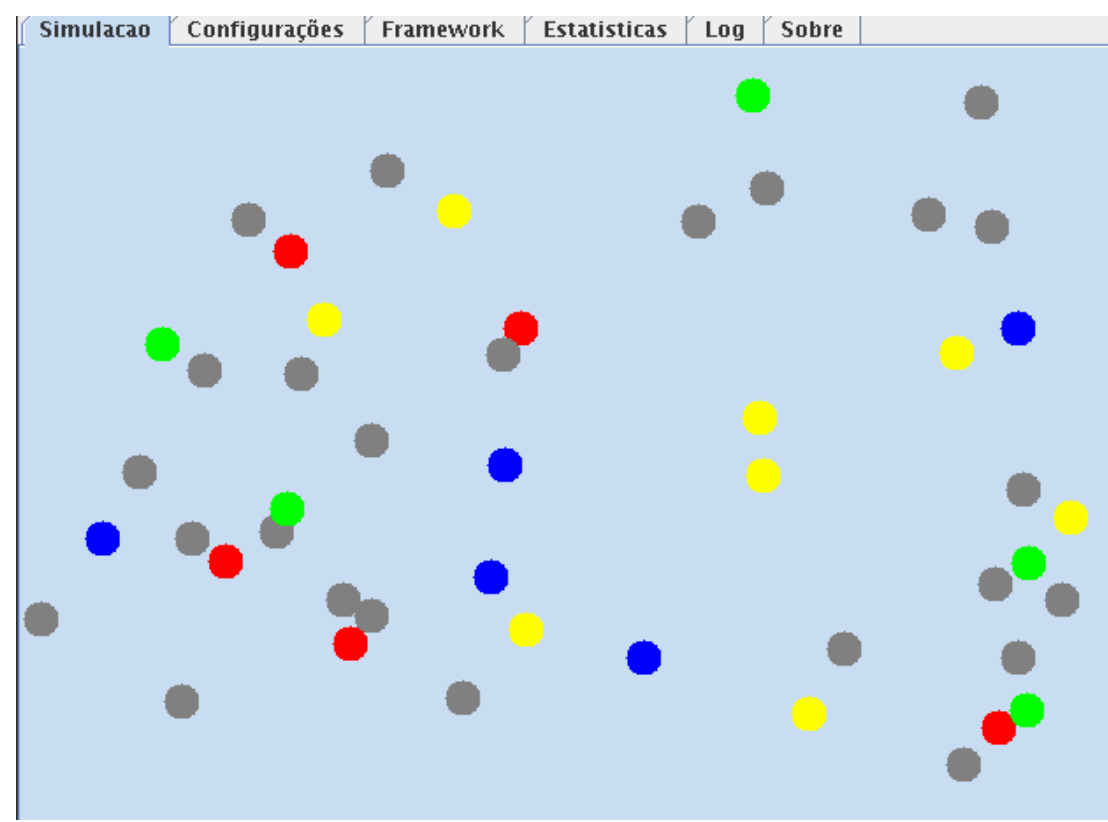

Figura 32: Tópico de Simulação Gráfica da dinâmica de tráfico.

O framework ou Arquitetura do Agente apresenta os parâmetros relacionados à Percepção, Cognição e Atuação. A visualização dos valores dos parâmetros pertencentes aos módulos é permitida após a seleção de um dos personagens na sociedade. Com isso tem-se o acesso as informações internas do humano, como por exemplo, o que ele estaria percebendo naquele dado instante. Além disso, dados relacionados ao processo de inferência bayesiana (I(f/c), Vc, Vf, $\alpha, \beta$, etc), à tomada 
de decisão (Roleta de Monte Carlo), ao sucesso ou não da ação sorteada entre outros, também são exibidos nessa área (Figura 33).

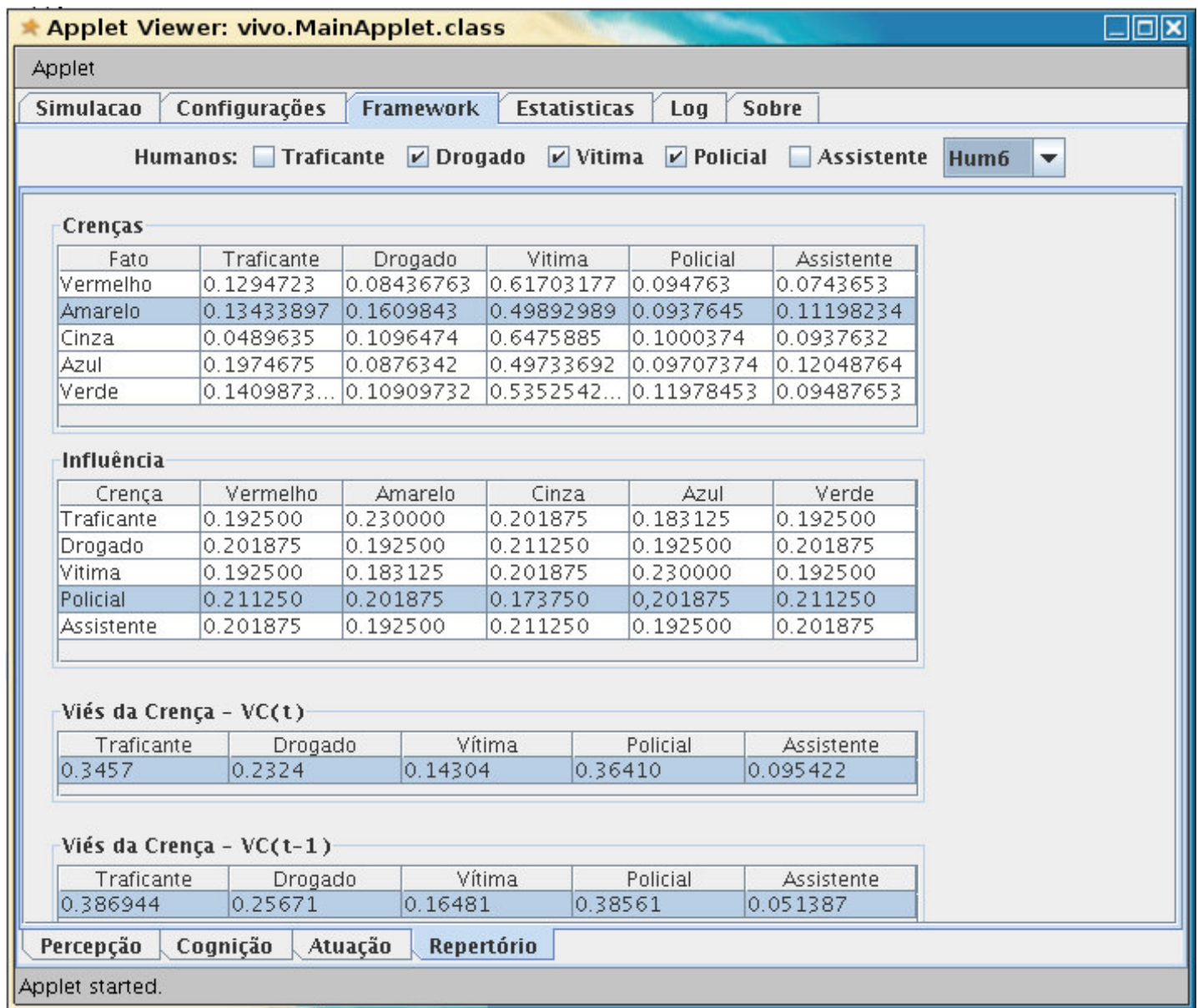

Figura 33: Tópico da arquitetura do agente contendo informações sobre o repertório de um determinado humano da sociedade.

\subsection{Metodologia Empregada}

As simulações possuem o caráter prático de validar o modelo proposto, sendo assim, o objetivo aqui é apresentar a adaptação e o ajuste dos níveis de certeza dos personagens através da interação social. Para isso pretende-se avaliar se os humanos conseguem aprender a identificar os papéis dos demais humanos observados.

Com esse intuito, atenta-se a observar a distribuição do $\mathrm{I}(\mathrm{f} / \mathrm{c})$ e dos respectivos níveis de certeza. Para realizar tais simulações foi estipulado um cenário padrão, um conjunto de valores comuns que se repetiu ao longo do processo de 
coleta de resultados. A descrição desse cenário utilizado é apresentada nas tabelas a seguir (Tabela 8, Tabela 9, Tabela 10, Tabela 11, Tabela 13, Tabela 13):

\begin{tabular}{|l|l|l|l|}
\hline Dimensão Espacial: & $150 \mathrm{~m}^{2}$ & Sociedade: & 40 humanos \\
\hline Densidade Demográfica: & $0,2667 \mathrm{hum} / \mathrm{m}^{2}$ & Interações & 70 \\
\hline Espaço Privado: & $3,75 \mathrm{~m}^{2} / \mathrm{hum}$ & Simulações & 5 \\
\hline
\end{tabular}

Tabela 8: Configuração do ambiente.

\begin{tabular}{|c|c|c|c|c|}
\hline Traficantes & Drogados & Vítimas & Policiais & Assistentes \\
\hline 05 & 12 & 18 & 03 & 02 \\
\hline
\end{tabular}

Tabela 9: Distribuição dos humanos entre os papéis.

\begin{tabular}{|c|c|c|c|c|}
\hline Vc(0) & $\mathbf{V f}(\mathbf{0})$ & I(f/c) & Tx. de Correção & Tx. de Flutuação \\
\hline 0,2 & 0,2 & 0,2 & 0,03 & 0,15 \\
\hline
\end{tabular}

Tabela 10: Configuração das Probabilidades Iniciais $(t=0)$.

\begin{tabular}{|c|c|c|c|}
\hline Fato & Fapriori $_{\text {ationça }}$ & Crencio & C $_{\text {apriori }}$ \\
\hline Vermelho & 0,21 & Traficante & 0,15 \\
\hline Amarelo & 0,19 & Drogado & 0,17 \\
\hline Cinza & 0,35 & Vitima & 0,48 \\
\hline Azul & 0,15 & Policial & 0,13 \\
\hline Verde & 0,10 & Assistente & 0,07 \\
\hline
\end{tabular}

Tabela 11: Configuração das Probabilidades a priori (F e C).

\begin{tabular}{|c|c|c|c|c|c|}
\hline Crença/Fato & Vermelho & Amarelo & Cinza & Azul & Verde \\
\hline Traficante & 0,2 & 0,2 & 0,2 & 0,2 & 0,2 \\
\hline Drogado & 0,2 & 0,2 & 0,2 & 0,2 & 0,2 \\
\hline Vítima & 0,2 & 0,2 & 0,2 & 0,2 & 0,2 \\
\hline Policial & 0,2 & 0,2 & 0,2 & 0,2 & 0,2 \\
\hline Assistente & 0,2 & 0,2 & 0,2 & 0,2 & 0,2 \\
\hline
\end{tabular}

Tabela 12: Valores iniciais da tabela $I(f / c)$ que serão corrigidos.

\begin{tabular}{|c|c|c|c|c|c|}
\hline Fato/Crença & Traficante & Drogado & Vítima & Policial & Assistente \\
\hline Vermelho & $?$ & $?$ & $?$ & $?$ & $?$ \\
\hline Amarelo & $?$ & $?$ & $?$ & $?$ & $?$ \\
\hline Cinza & $?$ & $?$ & $?$ & $?$ & $?$ \\
\hline Azul & $?$ & $?$ & $?$ & $?$ & $?$ \\
\hline Verde & $?$ & $?$ & $?$ & $?$ & $?$ \\
\hline
\end{tabular}

Tabela 13: Tabela de crenças NC(c/f) que serão calculados (a posteriori).

$\mathrm{Na}$ simulação as tabelas contendo as probabilidades a priori dos fatos e das crenças variam entre os personagens conforme uma taxa de flutuação definida antes 
do inicio da execução (Tabela 11). No caso, o valor utilizado da a taxa na simulação foi de $15 \%$ e todos os viés iniciam com valores equiprováveis (Tabela 10) e para coleta de resultados foram feitas 5 simulações com o mesmo cenário e com um total de 70 interações. Essas simulações foram realizadas com uma distribuição dos papéis entre a população de acordo com a Tabela 9.

\subsection{Resultados Obtidos}

O objetivo aqui é mostrar que o modelo proposto permite aos humanos virtuais ajustar suas crenças e em decorrência da calibração desses níveis de certeza, aprender a atuar em conformidade com seu conhecimento interno. Através deste objetivo foram levantados alguns parâmetros para serem observados.

\section{Nível de Certeza (C I Azul)}

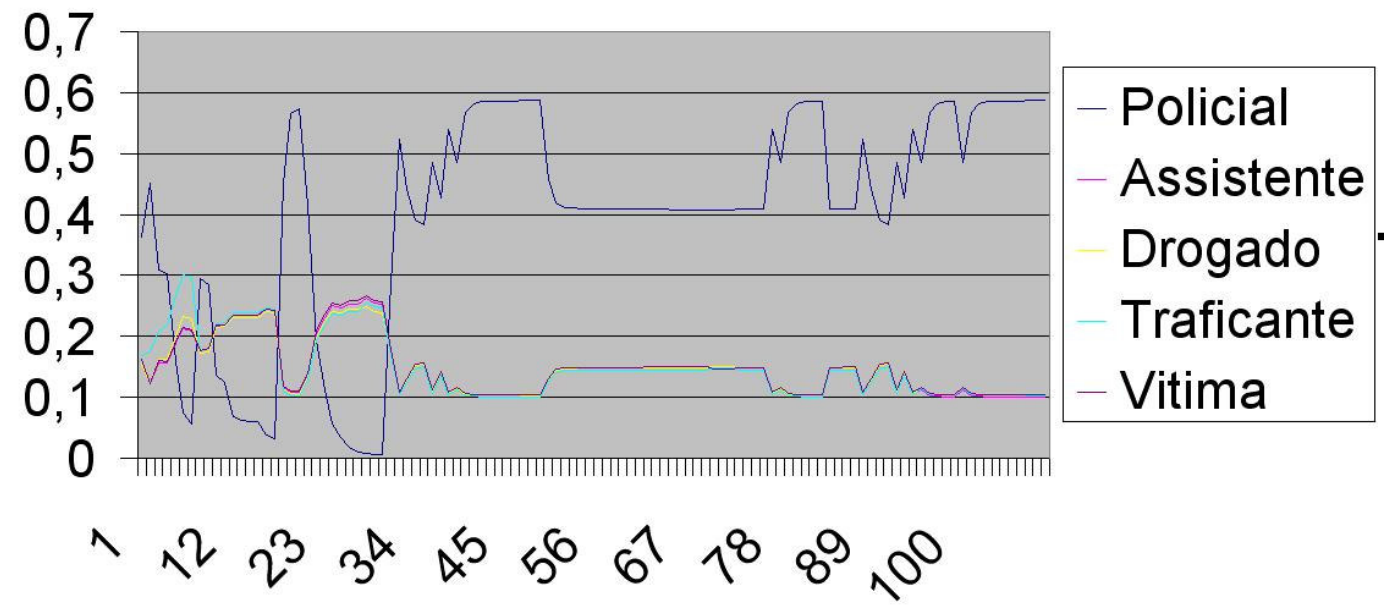

Figura 34: Curvas de convergência dos níveis de certeza.

Alguns dos parâmetros observados durante as simulações foram os próprios níveis de certeza das crenças a posteriori NC(c/f). Foram selecionados aleatoriamente alguns personagens e observados os comportamentos apresentados pelos níveis. Na Figura 34 pode-se observar que os valores partem de um mesmo nível e inicialmente nota-se um comportamento bem aleatório. No entanto, decorrido um certo número de iterações as curvas sinalizam patamares de convergência com singela flutuação. Sendo assim, pode-se avaliar que a partir das vinte iterações finais 
surge um padrão de recuperação, de recalibração, da verdadeira crença associada ao fato, onde esta se consolida como a crença determinante.

Um segundo parâmetro levantado foi a convergência do índice de Influência I(f/c), porém, este parâmetro foi avaliado sob seu caráter coletivo (Figura 35). Como o índice parte de valores equiprováveis e posteriormente esperava-se que eles dispersassem para definir as relações, optou-se por analisar o desvio padrão dessa amostragem.

As amostras utilizadas para o cálculo são os índices de influência de todos os humanos envolvidos. Devido aos ajustes sofridos os conjuntos de índices tendem a convergir para valores próximos aos tidos inicialmente como coerentes à modelagem da dinâmica. Essa convergência, que resulta em dados extremos, é evidenciada através da ascendência das curvas de desvio padrão.

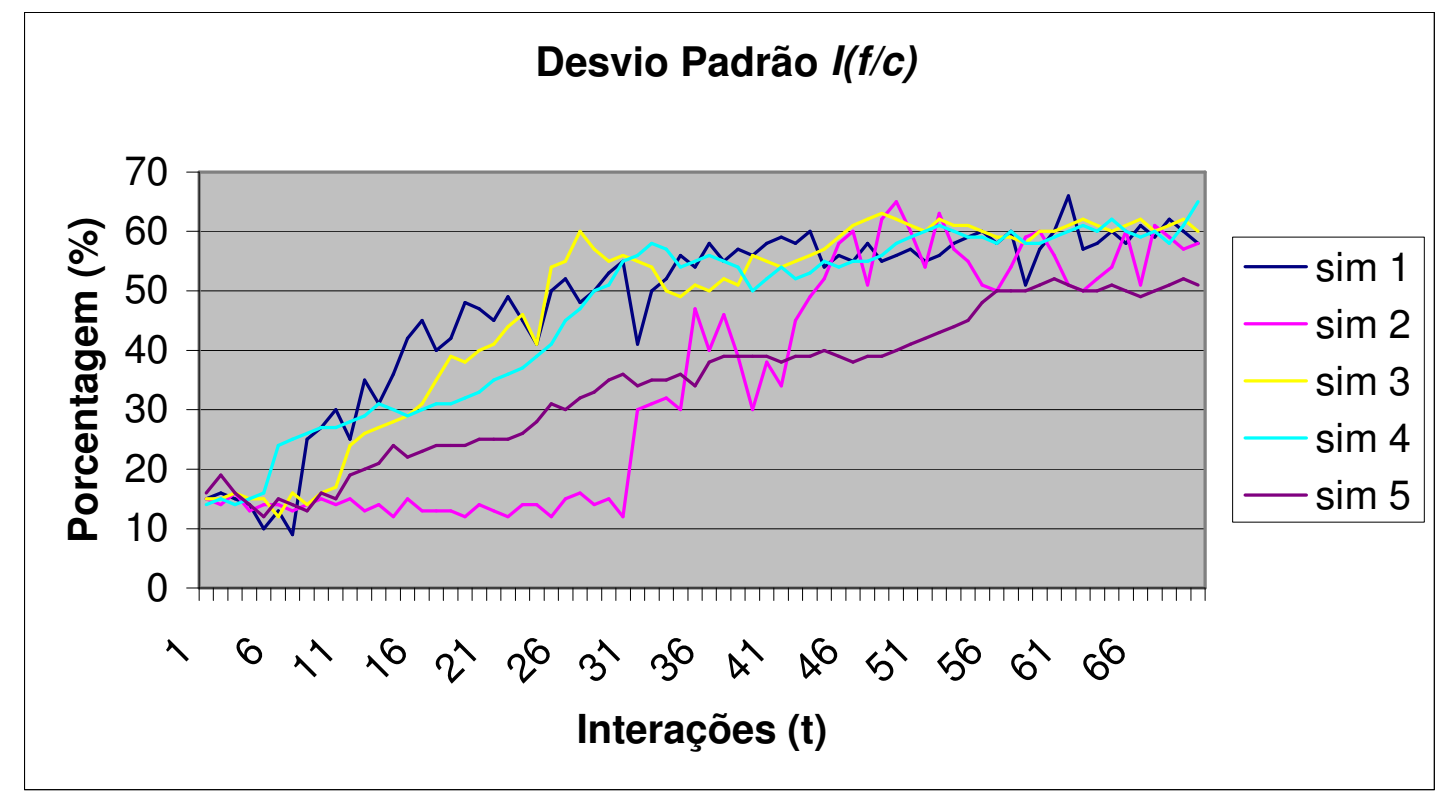

Figura 35: Gráfico de ascendência da dispersão (desvio padrão) dos índices de influência.

O mecanismo probabilístico usado aqui, o desvio padrão, foi considerado um bom aspecto a ser observado, pois refletiria a disposição dos valores dos índices de influência não apenas de um personagem, mas, no caso, de toda a sociedade. Assim, pode-se observar que existe uma convergência da sociedade como um todo.

A Figura 36 exibe as curvas de experimentação, o que vem a confirmar as expectativas. Devido ao comportamento das curvas é possível constatar e evidenciar 
as conseqüências da elevação dos níveis de certeza. A medida em que o humano se torna mais experiente e convicto do conhecimento, o personagem tende a desenvolver um comportamento que privilegie cada vez menos a experimentação de ações inicialmente incompatíveis com os seus níveis de certeza. Isto está de acordo com o modelo proposto e com a arquitetura implementada para os personagens.

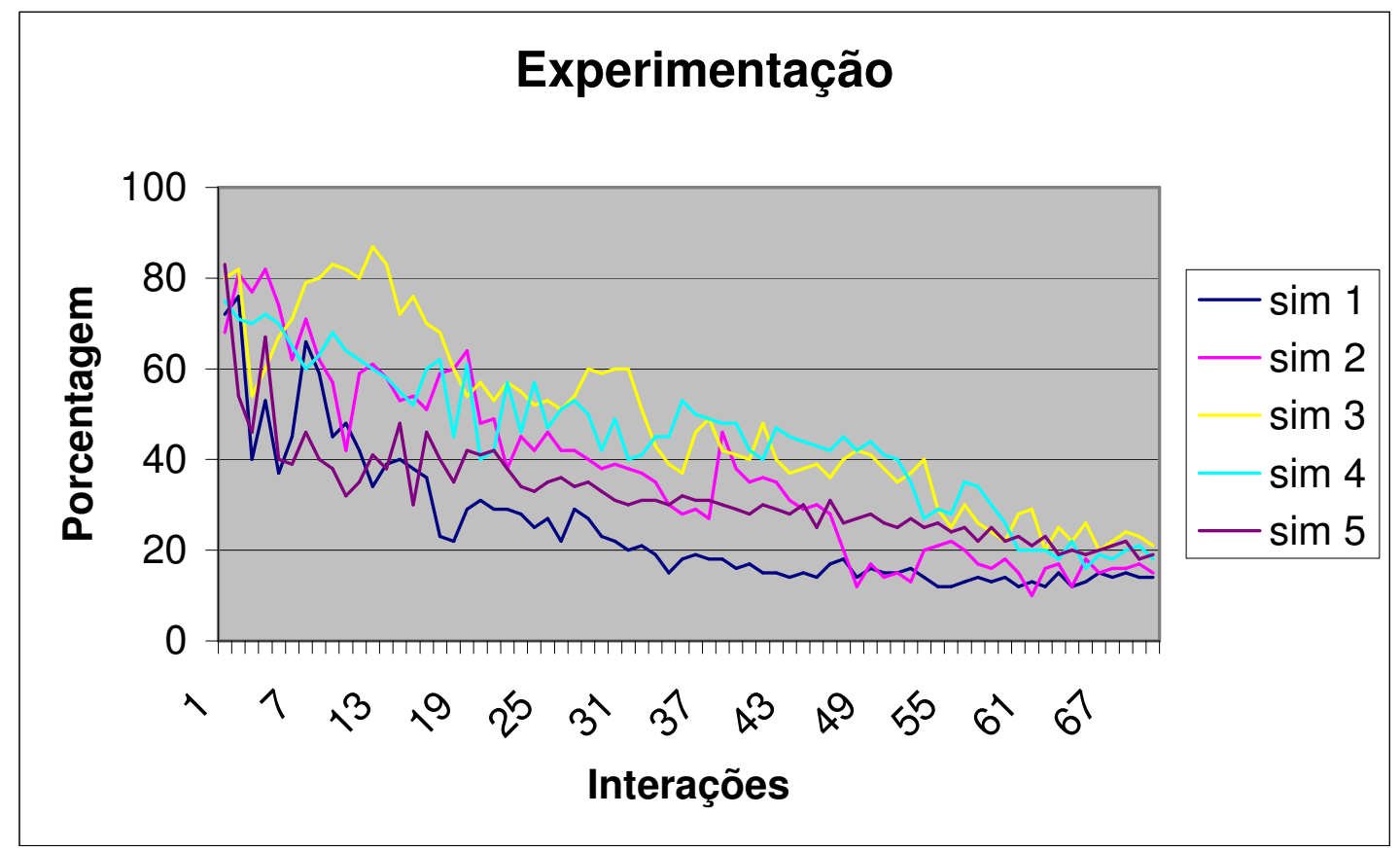

Figura 36: Curvas de experimentação da sociedade.

Esse comportamento desenvolvido pelos personagens pode ser explicado através da redistribuição das fatias associadas à Roleta de Monte Carlo. A medida em que o nível de certeza se eleva, as fatias das ações são corrigidas, diminuindo as experimentações como decorrência de fatias com baixas ponderações.

\subsection{Conclusões}

Para o processo de validação da pesquisa optou-se por efetuar dois tipos de análise: uma individual e outra coletiva. A primeira delas consistiu em efetivamente validar a arquitetura do agente para humanos virtuais através da avaliação individual dos níveis de certeza. 
A convergência desses níveis de certeza foi observada com base especificamente em um fato previamente selecionado e sempre analisado daquele mesmo personagem. Sendo assim, as curvas do comportamento desse parâmetro consolidaram o seu propósito de validar o modelo proposto, já que os resultados confirmam as expectativas geradas inicialmente.

Além do aspecto individual, o projeto necessitava ser testado ou ao menos realizar uma análise de como seriam os resultados sociais. Com esse objetivo de analisar a sociedade como um todo que se optou por observar alguns parâmetros coletados de todos os humanos. Esses parâmetros formaram um amplo conjunto de amostragem o que permitiu análises estatísticas.

As análises empregadas na validação sob o aspecto coletivo, sobretudo, o desvio padrão do parâmetro de influência, I(f/c), confirmam a convergência do sistema. Assim, os humanos são capazes de perpetuarem um quadro de adaptação, onde eles por deduções e observações aprendem a identificar os papéis de atuação e por consequiência atuar de modo mais eficiente na sociedade. Essas curvas, em particular, de desvio padrão mostram como os dados avaliados com essa métrica partem de relativa homogeneidade com poucas distorções e tendem a dispersar (a aumentar os valores do desvio). Essa constatação serve para ratificar a acomodação desses valores já que eles inicialmente haviam partido de uma distribuição equiprovável. 


\section{CONSIDERAÇÕES FINAIS}

"Todo o meu saber consiste em saber que nada sei"

[Sócrates]. 


\subsection{Contribuições Científicas}

A pesquisa aqui apresentada seguiu uma abordagem delimitada entre os escopos do conhecimento nas áreas de Vida e Inteligência Artificial. Para este fim, o objeto do trabalho foi o humano virtual, e de modo mais específico à simulação reduzida de sua mente - uma mente virtual.

A simulação serviu para avaliar a capacidade do personagem ir progressivamente se certificando dos papéis assumidos por outros personagens no seu ambiente, tomando como base àquilo que parecem ser (a partir da roupa que vestem) para estimar aquilo que realmente são (a partir do comportamento que desempenham na relação interpessoal). Por exemplo, um traficante encontrando um dependente tem sucesso se o identificar corretamente, o que é confirmado pela efetivação da venda da droga. Mas se falhar pode ser preso, ao tentar fazê-lo (vender droga) para um policial.

\subsubsection{Em Vida Artificial}

Em Vida Artificial, como já apresentado anteriormente ${ }^{21}$, existem trabalhos que se concentram em dois extremos: a visão "bottom-up" e a "top-down”. Esta pesquisa por sua vez, embora se destaque fortemente pelo seu contexto "top-down", pode ser apontada como uma espécie intermediária entre esses extremos.

A pesquisa se desenvolve através da proposta de um modelo de comportamento para humanos virtuais ("top-down”). Entretanto, o ajuste dos parâmetros que condicionam o funcionamento desse modelo é feito ao longo do tempo, tornando-se algo decorrente do processo empírico. Essa decorrência, ou construção que emerge do processo iterativo é similar ao funcionamento dos projetos contextualizados como “bottom-up”.

Essa abordagem promove contribuições em Vida Artificial por trabalhar com personagens providos de uma estrutura inteligente (arquitetura de agente) mais

\footnotetext{
${ }^{21}$ Vide capítulos 1 e 2 nas respectivas páginas 1 e 9.
} 
complexa que a maioria dos trabalhos na área ${ }^{22}$. Esse novo escopo de pesquisas promovido pela integração do comportamento inteligente ao desenvolvimento social reforça o conceito de apresentação de pesquisas em Vida Artificial $^{23}$.

$\mathrm{Na}$ literatura é comum encontrarmos trabalhos fortemente vinculados a um desenvolvimento de aspectos de filo e ontogênese ${ }^{24}$, mas a integração entre inteligência e comportamento social ainda é um tópico pouco explorado. Mesmo com os recentes trabalhos desenvolvidos sobre Humanos Virtuais ${ }^{25}$, estes tratavam a configuração dos parâmetros que condicionariam o comportamento de modo previamente estipulado e formatado.

Tendo em vista os esforços de pesquisa, o trabalho apresentado se destaca pela sua contribuição ao permitir que a sua arquitetura se adapte, principalmente por meio de iterações sociais compartilhadas entre os próprios personagens, esboçando assim, uma espécie de aprendizado. A adaptação da arquitetura do agente não apenas se valida sob o caráter individual, mas também pelo coletivo, onde os resultados confirmam uma evolução social.

\subsubsection{Em Inteligência Artificial}

No âmbito da Inteligência Artificial, o trabalho agregou conhecimento envolvendo processo de inferência, sistemas determinísticos e probabilísticos e arquitetura de agentes. Como contribuição fica a aplicação dessas tecnologias em Vida Artificial, onde foram combinados de modo a tornar mais eficiente e sofisticado o comportamento desempenhado por esses humanos virtuais.

O processo de Inferência Bayesiano se mostrou eficiente às necessidades do projeto e a forma com que este foi concebido. Basicamente precisava-se atribuir aos personagens a capacidade de deliberarem em um ambiente parcialmente observável e que por observação ele construísse um conhecimento interno. Assim, a estrutura de

\footnotetext{
${ }^{22}$ Arquiteturas fortemente vinculadas a uma operabilidade reativa.

${ }^{23}$ Representação da aderência e abordagem de um trabalho em Vida Artificial com base nos principais tópicos observados: filogenia/filogênese, ontologia/ontogênese e epistemologia. Vide página 12.

${ }^{24}$ Trabalhos como os desenvolvidos por Sims, K. (filo), Terzopoulos (onto) e os do grupo ARTLIFE com pesquisas em ambos os tópicos (pág. 14).

25 Pesquisas sobre comportamento social aplicado à humanos virtuais em Realidade Virtual desenvolvidos pelo VRLab cujo coordenador é Thalmann, D. (pág 38).
} 
funcionamento da Teoria de Bayes se mostrou benéfica pela sua reavaliação probabilística (a posteriori) com base no relacionamento entre conhecimentos $a$ priori mediante a constatação de evidências. Isso foi de encontro com as necessidades de como quantificar e transcrever esses eventos em conhecimento, uma vez que a ocorrência dessas evidências a serem observadas acaba contribuindo para o processo de desenvolvimento espistemológico do humano.

Além dessa habilidade incorporada à arquitetura do personagem, a adaptação também foi algo trabalhado, o que propiciou sistematizar a partir de visões individuais ou coletivas. Esse processo de adaptação compreendeu o ajuste e a calibração dos principais parâmetros que condicionaram o comportamento do personagem. Para que essa arquitetura pudesse se adaptar, alguns parâmetros tidos como "não-fixos" (flexíveis) e que influenciassem diretamente no comportamento foram vinculados ao processo adaptativo e por conseqüência passaram a sofrer correções (punições ou incentivos). Em termos práticos os parâmetros envolvidos nesse processo adaptativo foram: o índice de Influência entre Fato e Crença, I(f/c), e o próprio Nível de Certeza da Crença $c$ na ocorrência do Fato $f, \mathrm{NC}(\mathbf{c} / \mathbf{f})$.

As correções dos parâmetros estipulados (flexíveis) foram feitas com base em constatações que decorrem do sucesso ou não de ações tomadas e desse processo relacional surtiram bons resultados como pôde ser observado no capítulo anterior. Tais resultados, de certa forma, validaram a viabilidade desse tipo de agregação tecnológica. Entretanto, para isso foram necessárias algumas sutis modificações.

\subsection{A Evolução da Pesquisa}

O projeto inicialmente havia partido de uma proposta de pesquisa onde o objetivo final era a observação de uma dinâmica que contemplasse o convencimento entre dois personagens. Tal dinâmica que previa situações de convencimento seria condicionada por uma análise cognitiva dos fatores que ponderariam tal manifesto de persuasão. Entretanto, logo se descobriu que para isso ser trabalhado, antes seriam necessários alguns esforços sobressalentes tanto no âmbito do comportamento quanto do ambiente. 
Talvez o assunto de maior implicação direta em um primeiro instante seria a questão do ambiente. Na maior parte dos casos, os agentes se mostram incapazes de terem acesso e/ou conhecimento pleno do ambiente. Tomando isto como princípio, detectou-se que antes de iniciar estudos com respeito ao convencimento, seria necessário que os personagens tivessem a capacidade de compreender melhor o meio do qual fizessem parte. Através do aprendizado de como identificar o objetivo dos personagens na sociedade, conseguido por meio da observação, seria possível implementar futuramente um processo de persuasão melhor elaborado.

A combinação dessas habilidades traria personagens mais elaborados, com implicações em uma vasta gama de aplicações, que pode ser ilustrada em casos de cooperação, por exemplo. Nessas situações os personagens independentes de sua concepção de projeto aprenderiam a identificar os objetivos pessoais de cada um nessa sociedade e assim, num instante futuro iniciariam um processo de convencimento e barganha que pode retratar um intuito pessoal ou coletivo.

\subsection{Trabalhos Futuros}

Dando continuidade à pesquisa realizada até então, seria interessante destacar as seguintes propostas de atividades futuras.

Incorporação de uma interface gráfica tridimensional que se estendesse desde a representação dos personagens (humanos virtuais) até a utilização da Caverna Digital da USP. Essa transposição da pesquisa para tal dispositivo visaria propiciar um ambiente adequado para que haja um comprometimento, um sentimento real de presença e imersão que poderia favorecer uma melhor compreensão do fenômeno social estudado, neste caso a relação entre personagens de um cenário onde há tráfico de drogas.

Aprimorando o aspecto de interface do experimento, seria interessante dimensionar uma interface de interação. Atualmente o sistema se caracteriza por ser plenamente iterativo, ou seja, uma vez configurados os parâmetros de simulação, este não sofre alterações durante a sua execução. A abertura do sistema para torná-lo vulnerável a perturbações advindas do usuário poderiam ser benéficas e abrindo mais 
um espaço para estudos relacionados ao como os personagens seriam afetados com essa interferência. Neste caso estaríamos admitindo a introdução de avatares neste cenário, onde tais avatares são representações de humanos reais responsáveis por conduzir suas ações.

Existe ainda a possibilidade de permitir a migração entre os personagens de uma sociedade para outra ou então inserir um personagem novato em uma sociedade experiente. Essa mobilidade transformaria o sistema, que atualmente é fechado, em aberto. Além disso, os resultados do processo empírico poderiam ser reforçados com a inserção de ruídos e seres erráticos (parâmetros fortemente distorcidos).

Uma outra atividade futura de grande interesse seria tornar o sistema de agentes em um sistema multi-agentes, talvez usando a API para desenvolvimento desse tipo de aplicação para Java como a SACI (Hübner, 2006). A transposição do projeto para um sistema multi-agente ampliaria e muito a vazão relacionada à quantidade de agentes deliberando. Essa migração do projeto para um sistema multiagente permitiria a elevação considerável de personagens, o que abriria escopo para novas sociedades e até a facção em subsociedades.

Outra sensível modificação estaria diretamente ligada ao modelo estrutural da arquitetura do agente. Essa modificação consistiria em estar parametrizando os dois níveis básicos do módulo cognitivo. Atualmente eles são fixos e pré-estabelecidos como determinístico e probabilístico respectivamente para os processos de identificação da crença de maior significância e de tomada de decisão.

O mecanismo de inferência é baseado em um conjunto limitado de crenças e fatos o que acaba restringindo significativamente todo o potencial da arquitetura. Visando expandi-la, a aplicação da teoria de Bayes poderia ser tornar um recurso ainda mais sofisticado por meio de um sistema de múltiplas hipóteses e múltiplas evidências.

Outro recurso a ser considerado seria o uso de outras técnicas probabilísticas para efetivamente manipular a incerteza associada ao fato do ambiente ser parcialmente observável. Isso seria interessante se tivesse os seus resultados confrontados com os atuais que decorrem do uso de Teoria de Bayes. 
Uma outra vertente em potencial seria ainda o alcance em Vida Artificial de uma arquitetura plenamente "bottom-up", ou seja, uma arquitetura de agente que não exija uma engenharia de modelagem. No caso específico da simulação do trabalho, seria uma grande vantagem investir em um comportamento completamente emergente.

O trabalho atual foi desenvolvido com base em papéis, objetivos, ou seja, eles foram modelados explicitamente para que o comportamento do personagem decorrese disto. O caráter da emersão decorre do personagem ajustar corretamente os parâmetros de acordo com o seu objetivo. Agora, devido à intimidade com a tecnologia bayesiana e com a arquitetura sugerida em um primeiro instante, talvez, com algumas alterações, fosse possível a obtenção de uma arquitetura bayesiana de caráter de plena emersão.

Esta emersão implicaria no surgimento dos papéis, dos objetivos sem a necessidade de serem modelados, o que poderia resultar no surgimento de novos e/ou intermediários papéis. Isso seria obtido através da simplificação entre as ações e as crenças, o que tornaria a arquitetura ainda mais simples e viável para áreas como a indústria dos jogos (Netto, 2005b).

A partir desses aprimoramentos, tanto o ambiente quanto o modelo estariam estruturados de modo robusto e adequado para agregar o intento inicial da pesquisa, que era o poder de convencimento entre personagens. Sendo assim, através de estudos direcionados à área de Ciência Cognitiva, poder-se-ia desenvolver um modelo simplificado e parametrizado para ser implementado computacionalmente e posteriormente agregado ao presente sistema.

Como o processo de convencimento basicamente pode ser feito por persuasão e esse ato é compreendido pela comunicação estabelecida entre personagens, seria interessante implementar um processo mais sofisticado de comunicação. Tal implementação poderia ser realizada através de uma linguagem de comunicação entre agentes como o KQML (Knowledge Query and Manipulation Language). 


\section{LEVANTAMENTO BIBLIOGRÁFICO}

\section{Referências Bibliográficas}

Adami, C. and Brown T. What is Artificial Life?. Seventh International Conference on Artificial Life. Reed College, Portland, Oregon, USA. 2000.

Adami, C. Introduction to Artificial Life. Springer-Verlag, Telos. 1998. ISBN: 0387-94646-2.

Aquino, P. T. Jr. at all. Colaboração em Ambientes Virtuais Distribuídos com Dispositivos de Imersão. SBC. IV Symposium on Virtual Reality. Brasil. 2001. 148-159p.

Badler, N., Reich, B. B., Webber, B. L. Towards Personalities for Animated agents with Reactive and Palnning Behaviors. Lecture Notes in Artificial Intelligence, Creating Personalities for Synthetic Actors, 1997.

Balkenius, C. Natural Intelligence in Artificial Creatures. $\mathrm{PhD}$ thesis, Lund University Cognitive Science, Kungshuset, Sweden, 1995.

Bittencourt, G. Inteligência Artificial: Feramentas e Teorias. Editora da UFSC, Segunda Edição, Brasil. 2001.

Bond, A. H., Gasser, L. An Analysis of Problem and Research in DAI. Readings in Distributed Artificial Intelligence. San Mateo, California: Morgan Kaufmann Publishers. 1988. 3-35p.

Brega, J. R F. at all. Uma Biblioteca para Movimentação de Agentes e Avatares Humanóides em Aplicações de Realidade Virtual. SBC. IV Symposium on Virtual Reality. Brasil. 2001. 103-113p. 
Cardoso, A. at all. Ambientes Virtuais: Projeto e Implementação. SBC. VI Symposium on Virtual Reality. Brasil. 2003. 03p.

Cavalhieri, M. A, Netto, M. L. Modelo de Comportamento Baseado em Crenças e Teoria Bayesiana para Simulações de Vida Artificial com Humanos Virtuais. XVIII Brazilian Symposium on Computer Graphics and Image Processing. Brasil. 2005.

Cavazza, M., at all. Motion Control of Virtual Humans. IEEE CG\&A, Vol 18, No5. 1998. 24-31p.

Donikian, S. Towards Scenario Authoring for Semi-Autonomous entities. International Conference on Visual Computing. Goa, India. 1999.

Dorigo, M., Colorni, A. The Ant System: Optimization by a Colony of Cooperation Agents. IEEE Transsactions on Systems, Man and Cybernetics, Vol 26, No 2.1996.

Feller, W. An Introduction to Probability Theory and its Applications. Wiley, $3^{\text {rd }}$ edition. 1968.

Fernell, R. D., Lesser, V. Parallelism in Artificial Intelligence Problem Solving: A Case Study of Gearsay II. IEEE Transcation on Computers, v.26, n.2. 1977. 98$111 \mathrm{p}$.

Gleicher, M. Comparing Constraint-Based Motion Editing Methods. Graphical Models, Academic Press. San Diego, EUA. Vol 63. No. 2. 2001. 107-134p.

Hewitt C. Viewing Control Structures as Patterns of Passing Messages. Artificial Intelligence, v.8. 1977. 323-364p.

Houaiss, A. Dicionário Houaiss de Língua Portuguesa. Editora Objetiva. Brasil. 2001.

Huhns, M. N., Singh, M. P. Readings in Agents. Morgan Kaufmann, San Mateo, EUA. 1998. 
Jacob, L. J. at all. Avaliação de Técnicas de Interação em Ambientes Imersivos: Uma Proposta de Aplicação no Tratamento de Fobia de Altura. SBC. IV Symposium on Virtual Reality. Brasil. 2001. 12-22p.

Kirner, C., Pinho, M. S. Introdução a Realidade Virtual. Notas de Tutorial. Workshop de Realidade Virtual. Brasil. 1997.

Kwamoto, A. L. S. at all. AVC-MV: Um Ambiente Virtual Colaborativo para Aplicações Educacionais. SBC. IV Symposium on Virtual Reality. Brasil. 2001. 226-237p.

Langton, G. C. Artificial Life: An Overview (Complex Adaptive Systems). MIT Press; Reprint edition 1997. 1995.

Lee, C. C. Fuzzy Logic in Control Systems: Fuzzy Logic Controller, Part I. IEEE Transactions on Systems, Man, and Cybernetics. Vol. 20, Nro. 2. 1990. 404-418p.

Lee, C. C. Fuzzy Logic in Control Systems: Fuzzy Logic Controller, Part II. IEEE Transactions on Systems, Man, and Cybernetics. Vol. 20, Nro. 2. 1990. 419$435 p$.

Machado, L. S. at all. Modelagem Tátil, Visualização Estereoscópica e Aspectos de Avaliação em um Simulador de Coleta de Medula Óssea. SBC. IV Symposium on Virtual Reality. Brasil. 2001. 23-31p.

Meiguins, B. S. at all. Um Ambiente de Realidade Virtual Multi-Usuário Aplicado ao Setor de Turismo. SBC. IV Symposium on Virtual Reality. Brasil. 2001. 67-78p.

Menezes, G. L. B. B. de. at all. VRML como Ferramenta de Visualização de Escoamentos em torno de Corpos Simulados Numericamente. SBC. IV Symposium on Virtual Reality. Brasil. 2001. 114-124p.

Miranda, F. R. et al. An Artificial Life Approach for the Animation of Cognitive Characters. Computer \& Graphics, Vol. 25, 6ª Ed. Elsevier Science. Holanda. 2001. 955-964p. 
Morie, J. F. Inspiring the Future: Merging Mass Communication. Art, Entertainment and Visual Environment, Computer Graphics. 1994. 135-138p.

Musse, S. R. Behavioral Modeling of Virtual Human Actors. Revista de Informática Teórica e Aplicada, UFRGS, Vol 8, № 2. Brasil. 2001. 123-141p.

Musse, S. R., Thalmann, D. A Model of Human Crowd Behaviour: Group InterRelationship and Collision Detection Analysis. Proceedings of Workshop Eurographics Computer Animation and Simulation. Hungary. 1997.

Musse, S. R., Thalmann, D. Hierarchical Model for Real Time Simulation of Virtual Human Crowds. IEEE Transactions on Visualization and Computer Graphics, Vol.7, $\mathrm{N}^{\circ} 2,2001.152-164 p$.

Netto, M. L. at all. From Genetic Evolution of Simple Organisms to Learning Abilities and Persuasion on Cognitive Characteres. Revista de Informática Teórica e Aplicada, UFRGS, Vol 12, № 2. Brasil. 2005. 31-60p.

Netto, M. L. at all. Vida Artificial para Jogos. Tutorial Notes, Simpósio Brasileiro de Jogos para Computador e Entretenimento Digital. Brasil. 2005.

Netto, M. L. et al. Evolutionary Learning Strategies for Artificial Life Characters. Recent Advances in Simulated Evolution and Learning. Singapura. 2004.

Robert C. T. The Marx-Engels Reader. 1978. Norton. 2a. Edição. EUA. 204p.

Rodrigues, L. C. R, at all. Uso de Realidade Virtual na Vida Artificial. PreSymposium. VIII Symposium on Virtual Reality. Brasil. 2006.

Rosa, O. Jr. Ambientes Virtuais Cooperativos LRVCHAT3D, Um Estudo de Caso. SBC. IV Symposium on Virtual Reality. Brasil. 2001. 1-11p.

Russel, S., Norvig, P. Inteligência Artificial. Elsevier, Editora Campus, Tradução da Segunda Edição. Brasil. 2004. 34-54p. 
Silva, F. W., Apolinário, A. L. Júnior. Control Mechanisms for Computer Animated Agents. Proceedings of the Workshop on Virtual Reality. Brazil. 2000. 193-204p.

Sims, K. Evolving 3D Morphlogy and Behavior by Competition. Artificial Life. 1994.

Tavares, T. at all. Projeto e Implementação do ICSPACE: Um Espaço Cultural na Internet. SBC. IV Symposium on Virtual Reality. Brasil. 2001. 32-43p.

Teichrieb, Verônica, et al. Avatars as Interactive Guides for Navigation Assistance in three Dimensional Virtual Environment. Proceedings of the Workshop on Virtual Reality. Brazil. 2000. 215-226p.

Terzopoulos, D. Artificial Life for Computer Graphics. Communications of the ACM, Vol. 42, N 8, EUA. 1999. 33-42p.

Thalmann, D. Autonomous Virtual Humans. Tutorial Notes, III Workshop on Virtual Reality. Brazil. 2000.

Thalmann, D. et al. Avatars in Networked Virtual Environments. Wiley, England. 1999. 9, 130-139p.

Thalmann, N.M., Thalmann, D. Artificial Life and Virtual Reality. John Wiley and Sons. 1994.

Trindade, J. Realidade Virtual Conceitos e Aplicações. Tutorial Notes, II Workshop on Virtual Reality. Brasil. 1999. 03-12p.

Weiss, G. Multiagent Systems. MIT Press. EUA. 1999.

Wooldridge, M. An Introduction to MultiAgent Systems. John Wiley \& Sons, England. 2002.

Wooldridge, M., Jennings, N. Intelligent Agents: Theory and Practice. Knowledge Engineering Review. Cambridge University Press. United Kingdom. 1995. 
Wooldridge, M., Rao, A. Foundations of Rational Agency. Kluwer, Dordrecht, Netherlands. 1999.

Zadeh, L. A. Fuzzy Logic $=$ Computing with Words. IEEE Transactions on Fuzzy Systems. Vol. 4, Nro. 2. 1996. 103-111p.

Zadeh, L. A. Fuzzy Sets. Information and Control 8. 1965. 338-353p.

Zadeh, L. A. Outline of a New Approach to the Analysis of Complex Systems and Decision Processes. IEEE Transactions on Systems, Man, and Cybernetics. Vol. SMC-3, Nro. 1. 1973. 28-44p.

Zuffo, M. K., at all. Projetando e Construindo Mundos Virtuais em Cavernas Digitais. Tutorial Notes. IV Symposium on Virtual Reality. Brasil. 2001. 04-15p.

\section{Referências On-Line}

Active Worlds. Web Site do ambiente virtual compartilhado. $<$ http://www.activeworlds.com>. Acesso em: 02/05/2006.

Amaral, L. Comentarista do Fórum virtual do CGChannel sobre trabalhos tridimensionais: apresentadora virtual do Fantástico exibido aos domingos pela Rede Globo. <http://www.cgchannel.com/forum/viewthread?thread=10939>. Acesso em: 23/09/2004.

ANinformática. Coluna sobre informática do portal UOL. $<$ http://an.uol.com.br/2004/jun/09/0inf.htm>. Acesso em: 23/09/2004.

Batistão, A. Site de divulgação da Personagem Virtual KAYA. $<\mathrm{http}: / / \mathrm{www}$.vetorzero.com.br/kaya/index.html>. Acesso em: 04/05/2006.

Cognitio. Site do Núcleo de Ciência Cognitiva da USP. $<$ http://cognitio.incubadora.fapesp.br/portal>. Acesso em: 04/05/2006.

Cybelle. Site da chatterbot brasileira. <http://cybelle.cjb.net>. Acesso em: 27/04/2006. 
Hübner, J. F. Página do projeto Simple Agent Communication Infrasctructure (SACI). Grupo de pesquisas do Laboratório de Técnicas Inteligentes da USP. <http://www.lti.pcs.usp.br/saci>. Acesso em: 05/05/2006.

Kaehler, S. D. Duzzy Logic Tutorial. $<$ http://www.seattlerobotics.org/encoder/mar98/fuz/fl_part5.html\#PUTTING\%20IT \%20ALL\%20TOGETHER>. Acesso em: 17/01/2005.

Leonhardt, M. D. at all. "ELEKTRA: Um Chatterbot para Uso em Ambiente Educacional". $\quad<$ http://www.cinted.ufrgs.br/renote/set2003/artigos/elektrachatterbot.pdf>. Acesso em: 24/04/2006.

Lord of the Rings. Página do filme The Lord of the Rings desenvolvido pela New Line Cinema. <http://www.lordoftherings.net>. Acesso em: 05/05/2006.

Monsters, Inc. Página do filme Monsters, Inc. desenvolvido pela Disney/Pixar. $<$ http://www.pixar.com/featurefilms/inc >. Acesso em: 05/05/2006.

Musse, S. R. Página do Laboratório de Simulação de Humanos Virtuais (CROMOS Lab). <http://www.inf.unisinos.br/ cromoslab>. Acesso em: 02/05/2006.

Netto, M. L. Página do grupo de Vida Artificial (ARTLIFE). <http://www.lsi.usp.br/ artlife>. Acesso em: 08/05/2006.

Netto, M. L. Página do projeto ALGA. <http://www.lsi.usp.br/ alga>. Acesso em: 08/05/2006.

Neves, R. P. O. Página do projeto ALIVE. <http://www.lsi.usp.br/ rponeves>. Acesso em: 08/05/2006.

Página do grupo de pesquisas relacionadas a Mundos e Personagens Virtuais (MIRALab). Thalmann, N. <http://www.miralab.unige.ch>. Acesso em: 08/05/2006.

Sims, K. Página Pessoal com pesquisas desenvolvidas e áreas de interesse. <http://www.genarts.com/karl>. Acesso em: 08/05/2006. 
Sims, The. Site do jogo de simulação de vida humana. <http://thesims.ea.com/index_flash.php>. Acesso em: 08/05/2006.

Terzopoulos, D. Página Pessoal com pesquisas desenvolvidas e áreas de interesse. $<$ http://www.cs.toronto.edu/ dt>. Acesso em: 08/05/2006.

Thalmann, D. Página do grupo de pesquisas relacionadas a Personagens Humanos do Laboratório de Realidade Virtual (VRLab). <http://ligwww.epfl.ch>. Acesso em: 08/05/2006.

The Matrix. Página do filme The Matrix desenvolvido pela Warner Bros. $<$ http://whatisthematrix.warnerbros.com>. Acesso em: 05/05/2006.

Vilela, V. Comentarista do Fórum virtual do 3DOnline sobre trabalhos tridimensionais: $\quad$ apresentador virtual de esportes. $<$ http://www.3donline.com.br/forum/viewtopic.php?p=63866>. Acesso em: 08/05/2006. 